Prepared for the U.S. Department of Energy

under Contract DE-AC05-76RL01830

\title{
Synthesis Report on the Implementation of Building Energy Codes in China
}
S Bin
L Jingru
L Haiyan
M Evans
Y Congu
Z Xiajiao
M Halverson
L Siwei

S Bo

March 2011

Pacific Northwest

NATIONAL LABORATORY

Proudly Operated by Battelle Since 1965 



\title{
DISCLAIMER
}

This report was prepared as an account of work sponsored by an agency of the United States Government. Neither the United States Government nor any agency thereof, nor Battelle Memorial Institute, nor any of their employees, makes any warranty, express or implied, or assumes any legal liability or responsibility for the accuracy, completeness, or usefulness of any information, apparatus, product, or process disclosed, or represents that its use would not infringe privately owned rights. Reference herein to any specific commercial product, process, or service by trade name, trademark, manufacturer, or otherwise does not necessarily constitute or imply its endorsement, recommendation, or favoring by the United States Government or any agency thereof, or Battelle Memorial Institute. The views and opinions of authors expressed herein do not necessarily state or reflect those of the United States Government or any agency thereof.

\author{
PACIFIC NORTHWEST NATIONAL LABORATORY \\ operated by \\ BATTELLE \\ for the \\ UNITED STATES DEPARTMENT OF ENERGY \\ under Contract DE-AC05-76RL01830 \\ Printed in the United States of America
Available to DOE and DOE contractors from the Office of Scientific and Technical Information,
P.O. Box 62, Oak Ridge, TN 37831-0062;
ph: (865) 576-8401
fax: (865) 576-5728 \\ email: reports@adonis.osti.gov \\ Available to the public from the National Technical Information Service \\ 5301 Shawnee Rd., Alexandria, VA 22312 \\ ph: (800) 553-NTIS (6847) \\ email: orders@ntis.gov <http://www.ntis.gov/about/form.aspx> \\ Online ordering: http://www.ntis.gov
}




\title{
Synthesis Report on the Implementation of Building Energy Codes in China
}

\author{
Shui Bin ${ }^{\mathrm{a}}$ \\ LIN Haiyan ${ }^{\mathrm{b}}$ \\ YU Congu $^{\mathrm{c}}$ \\ Mark Halverson ${ }^{\text {a }}$ \\ SONG Bo ${ }^{b}$ \\ LIU Jingru $^{c}$ \\ Meredydd Evans ${ }^{\text {a }}$ \\ ZHU Xiajiao $^{\mathrm{b}}$ \\ LANG Siwei $^{\mathrm{b}}$ \\ ${ }^{a}$ Pacific Northwest National Laboratory \\ ${ }^{\mathrm{b}}$ China Academy for Building Research \\ ${ }^{c}$ Beijing Energy Efficiency Center
}

March 31, 2011 


\section{Contents}

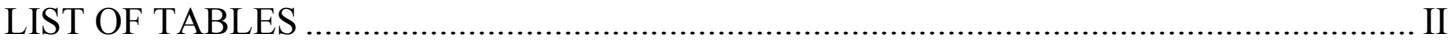

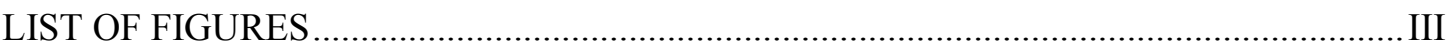

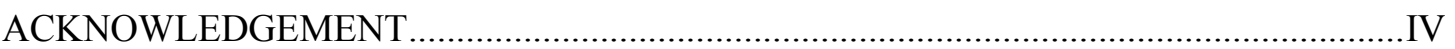

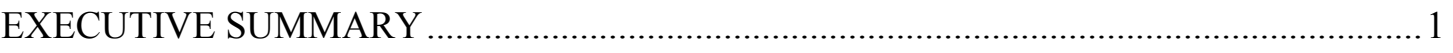

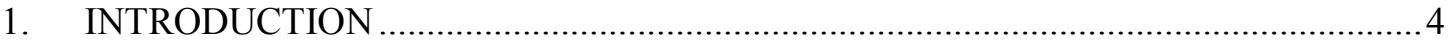

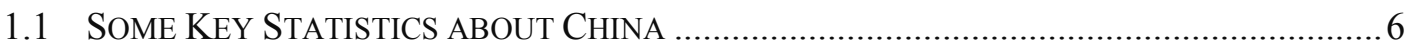

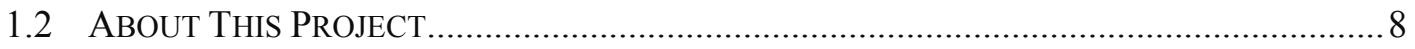

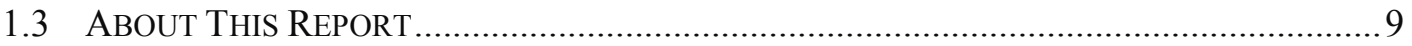

2. CHINA POLICIES FOR BUILDING ENERGY EFFICIENCY .................................... 11

2.1 The Evolution of Building Energy EfFiciency Policies ..................................13

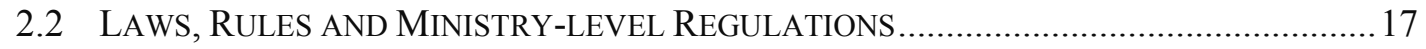

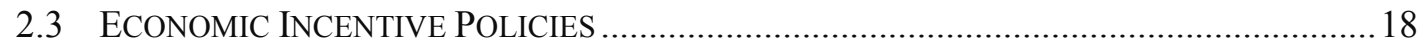

2.4 OTHER IMPORTANT NATIONAL POLICIES................................................................ 21

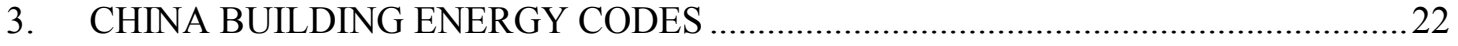

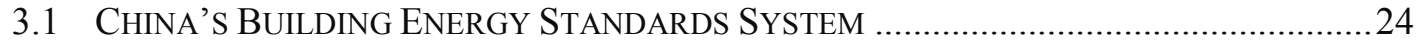

3.2 DESIGN STANDARDS FOR BUILDING ENERGY EFFICIENCY ........................................26

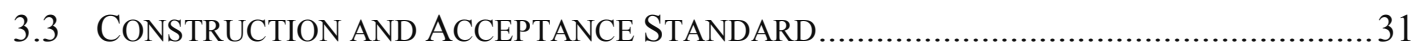

4. THE CURRENT IMPLEMENTATION OF BUILDING ENERGY CODES IN CHINA 33

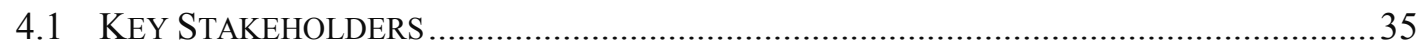

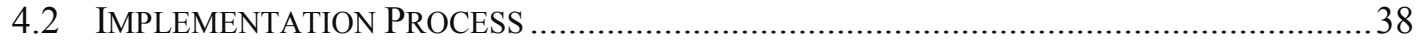

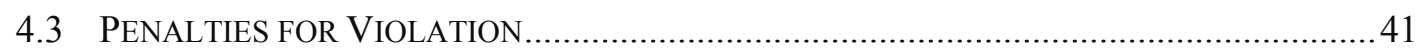

4.4 ANNUAL NATIONAL INSPECTION FOR BUILDING ENERGY EFFICIENCY .....................42

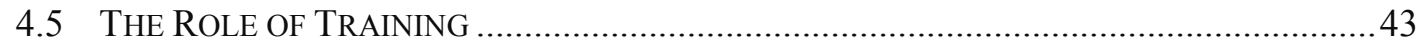

4.6 IMPLEMENTATION IN URBAN, SUBURBAN AND RURAL AREAS ....................................45

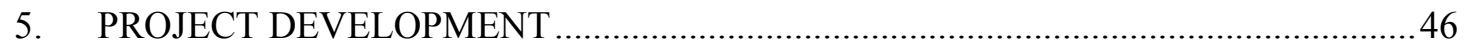

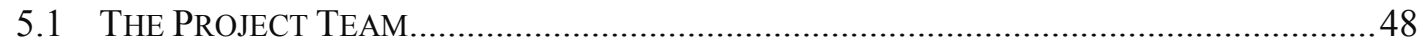

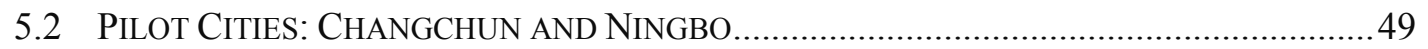

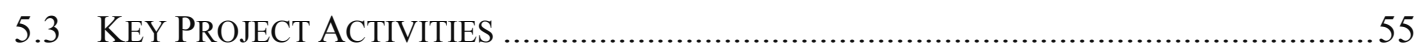

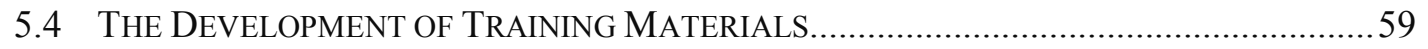

5.5 The DEVELOPMENT OF THE TRAINING WeBSITE AND ON-LINE TRAINING ................63

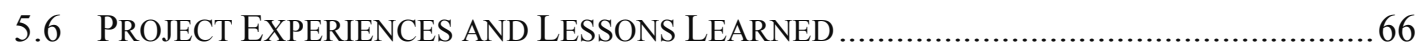




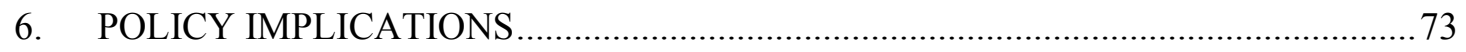

6.1 IDENTIFIED IMPLEMENTATION DIFFICULTIES AND THE ROLE OF TRAINING ...............75

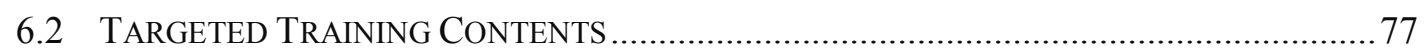

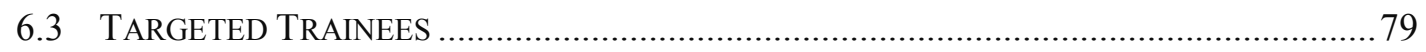

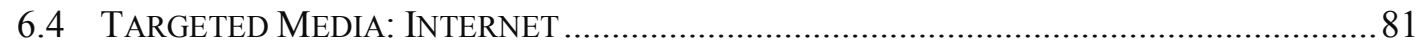

6.5 THE ROLE OF GOVERNMENT IN TRAINING AND INFORMATION DISSEMINATION ........83

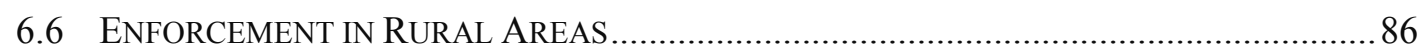

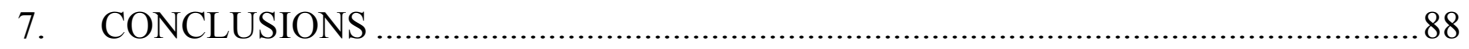

APPENDIX 1A DESIGN STANDARD FOR ENERGY EFFICIENCY OF RESIDENTIAL BUILDINGS IN SEVERE COLD AND COLD ZONES (JGJ 26-2010) ...............................91

APPENDIX 1B DESIGN STANDARD FOR ENERGY EFFICIENCY OF RESIDENTIAL BUILDINGS IN HOT SUMMER AND COLD WINTER ZONE (JGJ 134-2010) ................92

APPENDIX 1C DESIGN STANDARD FOR ENERGY EFFICIENCY OF RESIDENTIAL BUILDINGS IN HOT SUMMER AND WARM WINTER ZONE (JGJ 75-2003)................92

APPENDIX 2 DESIGN STANDARD FOR ENERGY EFFICIENCY OF PUBLIC

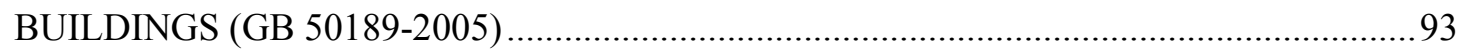

APPENDIX 3 CODE FOR ACCEPTANCE OF ENERGY EFFICIENT BUILDING

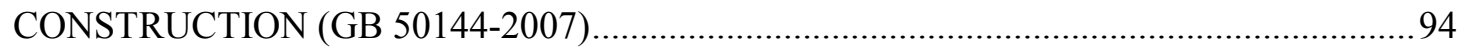

APPENDIX 4A ENFORCEMENT FRAMEWORK IN APP COUNTRIES .....................96

APPENDIX 4B TRAINING AND INFORMATION DISSEMINATION IN APP

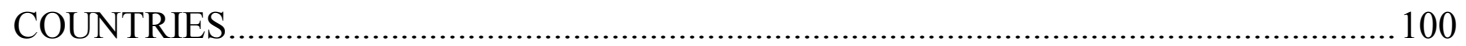

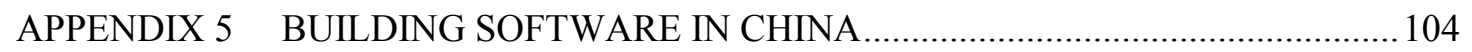

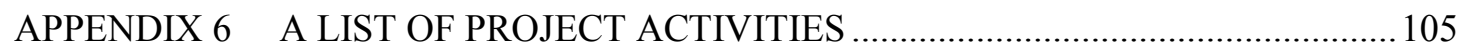

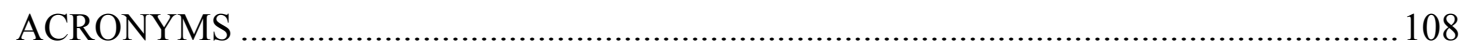

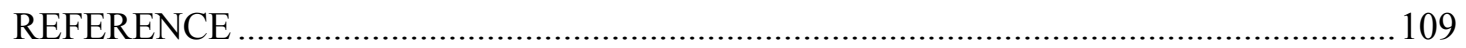




\section{List of Tables}

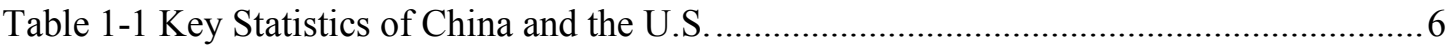

Table 2-1 Key Policy Activities for China's Building Energy Efficiency ............................... 13

Table 3-1 Structure Comparison of Building Energy Codes in APP Countries........................27

Table 4-1 Role of Third Parties in the Implementation of Building Energy Codes ..................37

Table 4-2 Average Education Level and Title Exams for Certificates by Stakeholders..........44

Table 5-1 Contents of Training Presentation Slides of China's Building Energy Codes.........61

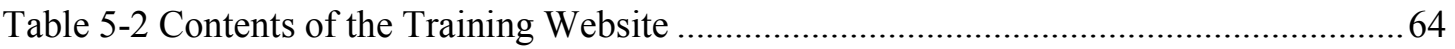

Table 6-1 Identified Implementation Difficulties by Local Stakeholders ................................ 75

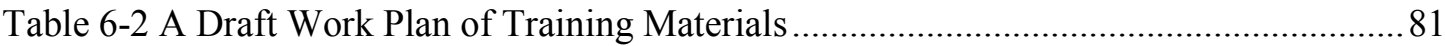




\section{List of Figures}

Figure 1-1 Total Energy Consumption by Sector in China, 1990-2005 ................................... 7

Figure 1-2 Annual Growth Rate of Building Energy Use in APP Countries (1995-2005) ........7

Figure 3-1 China's Building Energy Standards System.................................................25

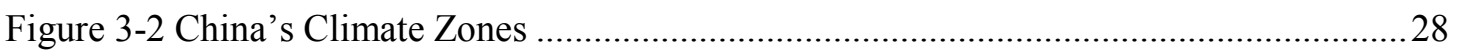

Figure 4-1 Key Stakeholders in the Implementation of Building Energy Codes in China ......36

Figure 4-2 The Implementation Process of Building Energy Codes in China .........................39

Figure 4-3 The Compliance Rate of Building Energy Codes in China in Cities Conducted the

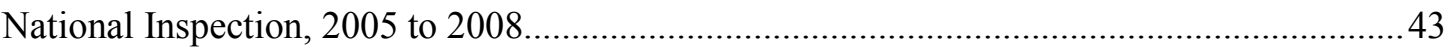

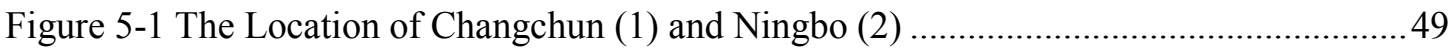

Figure 5-2 International Seminar on the Implementation of Building Energy Codes in APP

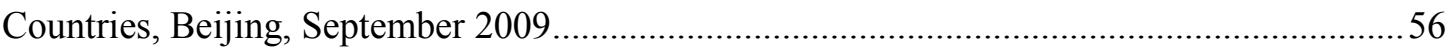

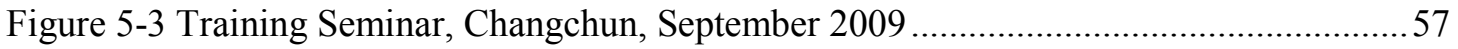

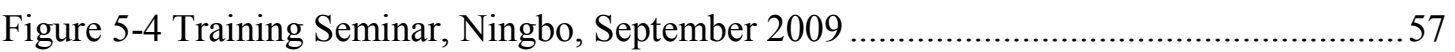

Figure 5-5 Some Training Slides of Design Standard for Energy Efficiency in Public

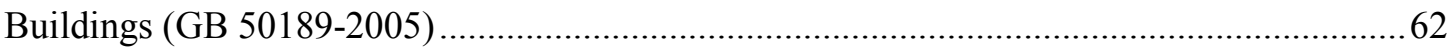

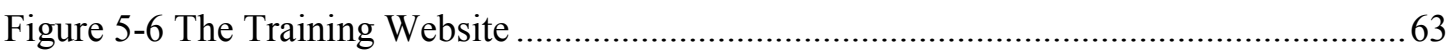

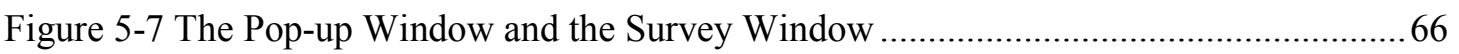

Figure 6-1 The Adoption of Residential Building Energy Codes by State ............................. 84

Figure 6-2 The Adoption of Commercial Building Energy Codes by State............................. 84 


\section{Acknowledgement}

This report owes its existence to the Asia-Pacific Partnership on Clean Development and Climate. We would like to thank Griffin Thompson, Barth Norman, Nancy Ahson, Garrett E. Barnicoat, Kevin Schwartz, Poliquin Boots from the U.S. Department of State for their leadership and financial support. We would also like to thank Mark Ginsberg from the U.S. Department of Energy for his support of this work.

We would like to express our gratitude to several other individuals who supported this report in various capacities, including Mike Davis, Evan Jones, Marylynn Placet, Tony Janetos, Kay Killingstad, Leon Clarke, Kali Wood, Tanya Smith, Anita Jeff, Kim Swieringa, and Paulette Land at Pacific Northwest National Laboratory. Andrew Mizrahi provided editorial assistance. Eric Makela provided peer review of this report.

This report also owes a great deal to local officials in Ningbo and Changchun who provided tremendous support and participation. They are Shen Qitian, Wang Yang, Li Tiesheng, Kang Hengxin, Liu Honglin, Zhu Shouzheng, Zheng Chengyan, Bu Fangxiang, Huang Hai, Yin Huanqi, Li Yunchang, Jin Dalong, Pan Yanping, Li Yan, Zhan Yongchang, Ma Da, Yang Hongming, Gu Futian, and Gao Qing in Changchun, and Fang Xinbiao, Zhang Shunbao, Ying Aiyi, Zhu Yinxing, Chen Yongyuan, Pei Jianan, Lin Mi, Cheng Zhenghui, Liu Ming, Hu Chuanwei, Luo Hong, Gong Xuemei, Zhang Zhiying, Zhu Jiping, and Wang Chengdong in Ningbo. 


\section{Executive Summary}

China is the new leader in the global construction market, with $\$ 1,000$ billion invested into new construction projects in $2010^{1}$. With its already significant building stock, high construction rate of new buildings, and strong governmental commitment to improving building energy efficiency, China is positioned to have great influence on global building energy use in the years to come.

Building energy efficiency was first addressed in the mid 1980s, after China developed its new political doctrine of "Socialism with Chinese Characteristics" in the late 1970s and launched its unprecedented economic reform.

Since then, the development of building energy efficiency policy has gone through into five stages: (1) early research and preparation, (2) pilots and demonstrations, (3) institution development and goal setting, (4) goal implementation, and (5) development and implementation of an array of policies and projects promoting building energy efficiency (Chapter 2). Building energy standards and codes are one important policy instrument targeted by Chinese government.

Over three decades of governmental efforts, China has successfully established a comprehensive system of building energy standards and codes. The system covers the life cycle process of a building project, from design, construction and acceptance, inspection, evaluation, modification, products and selection of building materials to building operation. This project, the DOS project ${ }^{2}$, is focused on the implementation of four building energy codes: three of which are design standards (two for residential buildings and one for public/commercial) and one is a code of construction and acceptance (Chapter 3).

The current implementation status of building energy codes in China is a tale of two extremes: while there is no implementation in rural areas, the implementation in urban areas is very encouraging. The compliance rates of building energy codes in both the design and construction stages in the inspected large- and mid-size cities were a stunning $98 \%$ and $90 \%$, respectively, in 2009 .

\footnotetext{
${ }^{1} \mathrm{http}: / /$ www.ft.com/cms/s/0/f9c3e0ca-44ed-11e0-80e 7-00144feab49a.html

2 The project, titled the Implementation of Building Energy Codes in China, is led by Pacific Northwest National Laboratory, with collaboration with China Academy of Building Research and Beijing Energy Efficiency Center. The majority of the project funding is from U.S. Department of State. The project is hence called the DOS project by the project team.
} 
The impressive compliance rates come from establishing an implementation system that consists of a complete loop of the monitoring and inspection subsystem: building design companies, building inspection companies, construction companies, construction inspection companies, testing companies and labs (all of them are third parties), and semi-governmental quality supervision stations to oversee the implementation process (Sections 4.1 and 4.2).

Besides the unique, active engagement of third parties, China's implementation practices are also equipped with strict penalties for violations (Section 4.3), annual inspection for building energy efficiency (Section 4.4), and comprehensive national title exams for key stakeholders (Section 4.5.1).

So, what are the challenges faced by key stakeholders when they implement building energy codes? Through stakeholder meetings, focus group meetings, training seminars, onsite construction visits, and personal communications, the project team concluded that training and information dissemination is the ignored, under-invested, and weak component in China's current implementation practices (Section 6.1).

The project team also identified

(1) a list of targeted training contents, such as the Code for Acceptance, training on building technologies and materials, and building life-cycle cost analysis (Section 6.2);

(2) a list of new trainees: building developers (an entity to initiate a construction project), consumers (a powerful but unpredictable market pull), and construction workers (an entity to realize building design and code requirement through nails and bricks), with a draft work plan of training materials for all stakeholders (Section 6.3); and

(3) The targeted media, internet, considering China's online population of 457 million (Section 6.4) .

The project team also called upon the Chinese government to be more actively involved in supporting offline (the development of training materials), online (an official building energy codes website, online training) and onsite (training seminars, annual national conference of building energy codes) training and information dissemination activities by, among other things, providing financial resources (Section $6.5)$.

The goal of the DOS project was to improve understanding of the implementation status of building energy codes in China and to improve the implementation of building energy codes through training and information dissemination activities such 
as (1) the development of training materials (Section 5.4), and (2) the development of China's first training website devoted to providing free online training materials (Section 5.5).

The DOS project was developed in the midst of China's fast-evolving policy environment to promote building energy efficiency. As one of the first large-scale U.S.-China collaborative projects related to building energy codes in China, the project not only provided an excellent learning and collaboration opportunity for the building energy codes communities of both countries (Section 5.6), but also supported many innovative project activities for the first time (Chapter 7).

The Training and Information Dissemination Activities Supported by the DOS Project:

- The DOS project produced China's first building energy codes training website, with free online training materials and related information http://zmjnpx.chinabec.cn;

- CABR and PNNL conducted China's first online training activity, with $\mathbf{5 8 0}$ visits nationwide in the first two months;

- The DOS project conducted two on-site training seminars in Changchun and Ningbo, with more than $\mathbf{1 4 0}$ local participants;

- CABR uploaded their full-version training materials of four national building energy codes online for the first time; and

- The project team conducted the first in-depth policy analysis of China's implementation of building energy codes.

The project team hopes that the conclusion of the DOS project will be the start of more rewarding collaborative experiences between building energy codes communities in both countries, which will help improve building energy efficiency at global, national and local levels. 


\section{Introduction}




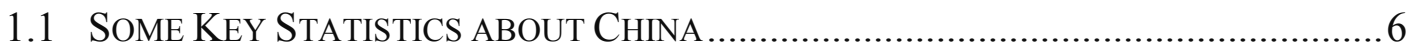

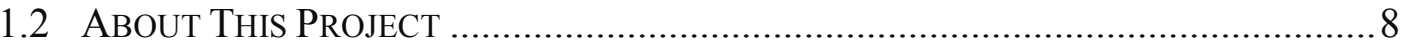

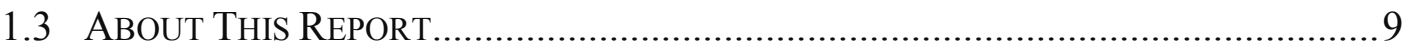




\subsection{Some Key Statistics about China}

With remarkable economic growth in the past three decades, China has transformed into a top-two global economy, energy producer and consumer, $\mathrm{CO}_{2}$ emitter and construction market (Table 1-1).

Table 1-1 Key Statistics of China and the U.S.

\begin{tabular}{|l|r|r|}
\hline & \multicolumn{1}{|c|}{ China } & \multicolumn{1}{|c|}{ U.S. } \\
\hline GDP & 2 & 1 \\
\hline World Ranking in 2010 & 5.7 & 14.6 \\
\hline GDP (trillion US\$ in 2010), estimated & $17.0 \%$ & $3.9 \%$ \\
\hline Annual Growth Rate (2000-2010) & 1 & 2 \\
\hline Primary Energy Production & 83.5 & 77.5 \\
\hline World Ranking in 2008 & $11.1 \%$ & $0.3 \%$ \\
\hline Value (EJ in 2008) & & \\
\hline Annual Growth Rate between 2000 and 2008 & 2 & 1 \\
\hline Primary Energy Consumption & 90 & 105 \\
\hline World Ranking in 2008 & $11.2 \%$ & $0.03 \%$ \\
\hline Value (EJ in 2008) & 1 & \\
\hline Annual Growth Rate (2000-2008) & 7,707 & 2 \\
\hline Carbon Dioxide Emissions & $11.7 \%$ & 0.524 \\
\hline World Ranking in 2009 & & $0.9 \%$ \\
\hline Value (million metric ton of $\mathrm{CO}_{2}$ emissions) & & \\
\hline Annual Growth Rate (2000-2009) & & \\
\hline
\end{tabular}

Source: International Monetary Fund 2010, EIA 2010a, EIA 2010b, EIA 2010c

China accounted for $14 \%$ of the world's total building energy use in 2005, which ranks second, just behind the U.S. (International Energy Agency 2007). The soaring building energy use in China is largely fueled by the country's rocketing economic growth, the rising standards of living, fast-expanding urbanization, as well as the booming construction industry.

Building energy use is the second largest sector in China (Figure 1-1). It accounted for 29\% of China's total energy consumption in 2007 (International Energy Agency 2009). 

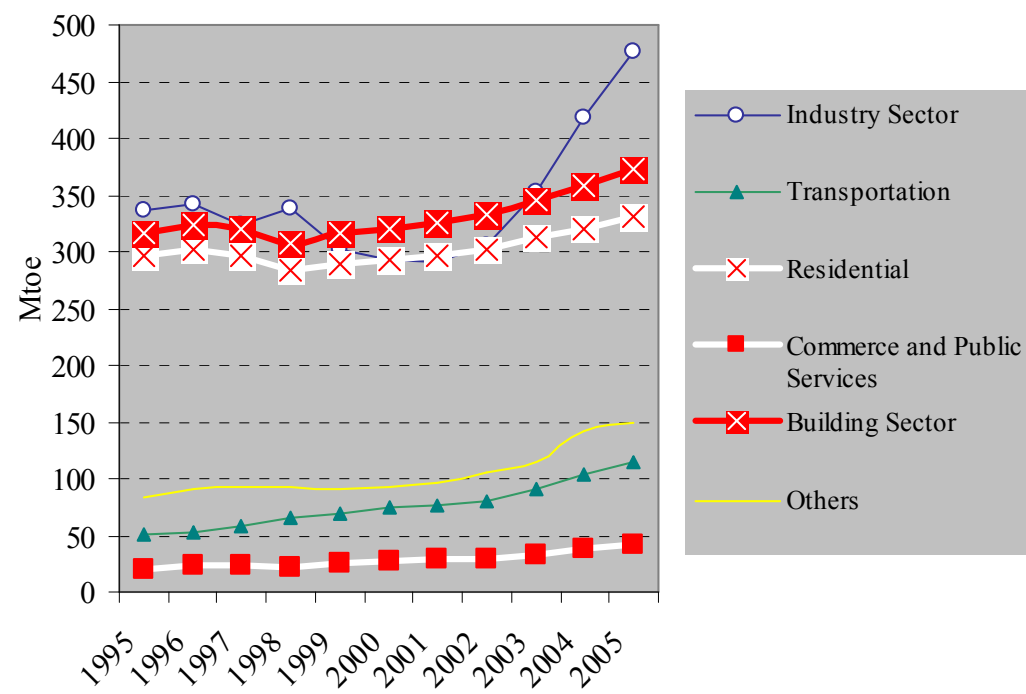

Notes: (1) Energy consumption in this figure refers to final energy use, which includes consumption of renewable and waste energy; the sector "Others" includes agriculture, forestry, fishing, and non-specified and non-energy use. (2) Energy in building sector is the sum of energy of the residential and commercial sectors.

Source: International Energy Agency 2007

Figure 1-1 Total Energy Consumption by Sector in China, 1990-2005

Residential energy use in China was the world's second largest in 2005, trailing only the U.S. Energy use for space heating is the largest end use in Chinese homes, followed by cooking and lighting (BECon 2010).

China is a top energy user in the commercial building sector. From 1995 to 2005, the annual growth rate of building energy use in commercial (including for public use) buildings accounted for $7.7 \%$, the highset of all AsianPacific Partnership (APP) countries $^{3}$ during the same period (International Energy Agency 2007) (Figure 1-2). Commercial building energy use

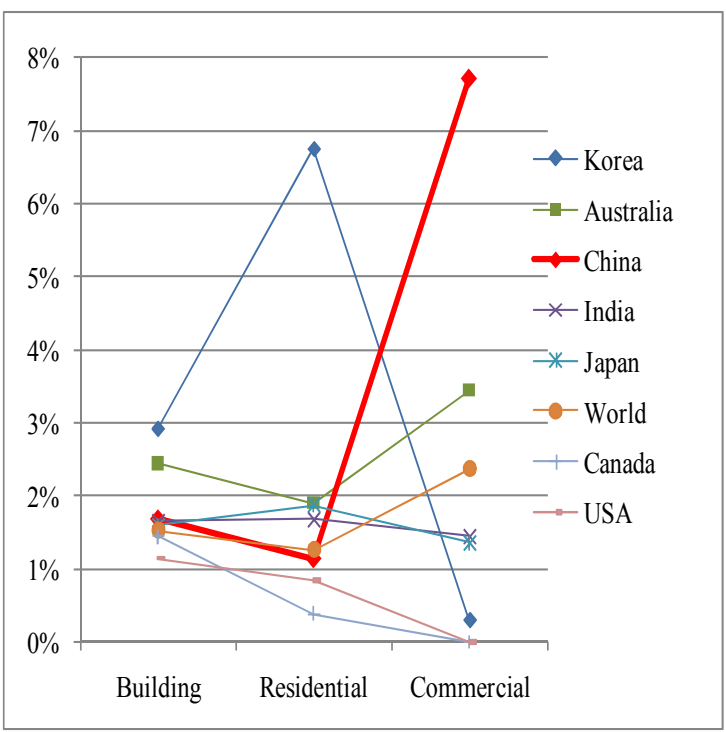

Source: International Energy Agency 2007

Figure 1-2 Annual Growth Rate of Building Energy Use in APP Countries (1995-2005)

\footnotetext{
${ }^{3}$ APP countries include Australia, Canada, China, Japan, India, South Korea, and the U.S.
} 
has a wide variation by building and business type and climate zone. Heating, ventilating, and air conditioning (HVAC) is the largest energy end user in large-scale commercial buildings (> 20,000 square meters or 215 square feet) (BECon, 2010).

China's construction industry, which accounts for 5.6\% of GDP, is one of the fastest growing industries in China. In recent years, China has added 1.8 to 2.2 billion square meters annually, making it the world's largest market for new construction (Wu and Liu 2007; Wu et al. 2007). Among these new buildings, $60 \%$ are residential, $10 \%$ are industrial and $30 \%$ are public or commercial (Lang 2005). According to the most recent China Statistics Yearbook, the floor space under construction and completed in China were about 5.3 and 2.2 billion square meters (57.05 and 23.68 billion square feet) in 2008, respectively, with an annual growth rate of $14-16 \%$ between 2000 and 2008 (China Statistics Bureau, 2010).

With its already significant building stock and high construction rate of new buildings, China is positioned to have great influence on global building energy use and related carbon emissions in the years to come.

\subsection{About This Project}

Under the framework of the Asia-Pacific Partnership on Clean Development and Climate (APP) ${ }^{4}$, Pacific Northwest National Laboratory (PNNL) collaborated with China Academy for Building Research (CABR) and Beijing Energy Efficiency Center (BECon) on a project to improve the implementation of building energy codes in China. The project, supported by the U.S. Department of State, lasted from November 2008 to March 2011. The project is called the DOS project by the project team.

The goal of this project is to improve the implementation of building energy codes through key project activities such as (1) the development of training materials that are more easily understood by trainees with less technical background and (2) the development of China's first training website devoted to providing free online training materials. The project also aims to improve understanding about the implementation status of building energy codes in China, which may help pave the way for follow-up collaboration on the implementation of building energy efficiency in China.

Over three decades of efforts, China has successfully established a comprehensive system of building energy standards. This project is focused on the implementation of

\footnotetext{
${ }^{4}$ APP is an innovative effort to accelerate the development and deployment of clean energy technologies between Partner Countries, including Australia, Canada, China, India, Japan, Korea, and the United States. "Buildings" is one of eight sectors focused on by this initiative. Please see http://www.asiapacificpartnership.org/english/default.aspx for details.
} 
three design standards for building energy efficiency (two residential building energy codes and one public building energy code) and a code for acceptance:

- Design Standard for Energy Efficiency of Residential Buildings in Severe Cold and Cold Zones (JGJ 26-1995, 2010);

- Design Standard for Energy Efficiency in Residential Buildings in the Hot Summer and Cold Winter Zone (JGJ134-2001, 2010)

- Design Standard for Energy Efficiency in Public Buildings (GB 50189-2005); and

- Code for Acceptance of Engineering Quality of Building Energy Conservation Project (GB50411-2007)

The cities of Ningbo, Zhejiang province, and Changchun, Jilin province, were selected as pilot cities for this project.

\subsection{About This Report}

The synthesis report has seven chapters. Besides the introduction (Chapter 1) and conclusions (Chapter 7), the main chapters are the following:

Chapter 2 reviews a series of policy and regulatory efforts by the Chinese government to improve building energy efficiency within the past three decades (Section 2.1), especially on laws and regulations (Section 2.2), economic policies (Section 2.3) and other key national policies (Section 2.4). This chapter helps readers understand the policy environment of the development of building energy codes in China.

Chapter 3 focuses on the introduction of an important policy instrument, building energy codes in China. The chapter provides an introduction of China's building energy standard system (Section 3.1), and a review of the historical development of four targeted building energy codes (JGJ26, JGJ134, GB50189 and GB50411), brief discussions of the most updated design codes (JGJ26-2010 and JGJ134-2010) (Sections 3.2 and 3.3).

Chapter 4 introduces the current implementation practice of building energy codes in China, including institution mechanisms and roles of key stakeholders within the institution (Section 4.1), the specific implementation process (Section 4.2), and the information about penalties when violations happen (Section 4.3). An annual national inspection for building energy efficiency since 2005 is also a part of China's

\footnotetext{
${ }^{5}$ During the project development, JGJ26-1995, issued in 1995, was later revised and issued in 2010.

${ }^{6}$ During the project development, JGJ134-2001, issued in 2001, was later revised and issued in 2010.
} 
monitoring and inspection system (Section 4.4). Chapter 4 also provides an overview about current training activities of building energy codes in China (Section 4.5), which is a reference point for the developed training activities detailed in Chapter 5. There is a brief discussion about the implementation status in urban, suburban and rural areas, which provides a glimpse of the whole look about China's implementation status (Section 4.6).

Chapter 5 is about the project development, starting with the introduction of the project team (Section 5.1), pilot cities (Section 5.2), and key project activities (Section 5.3). The focus of Chapter 5 is the development of training materials (Section 5.4), a training website and online training (Section 5.5). The project team also summarized its experiences and lessons learned from the project development (Section 5.6).

Policy suggestions are discussed in Chapter 6. Based on implementation issues identified throughout the project development, the project team concluded that training is a weak link in the current implementation system (Section 6.1), and suggested that the central government may consider investing more financial and policy support to training and information dissemination activities (Section 6.5). The chapter discussed targeted training topics (Section 6.2), targeted trainees (Section 6.3), and targeted media approaches (Section 6.4) to improve the quality of training and information dissemination activities, hence improve the implementation of building energy codes. Policy suggestions on enforcement in rural areas are also briefly discussed (Section 6.6).

The synthesis report contains several appendixes which may be of interest for readers. The appendixes include the content outlines of targeted China building energy codes (JGJ26, JGJ134, GB50189 and GB50411). A brief review of the implementation of building energy codes in APP countries, which focuses on their enforcement framework and training activities, is presented in Appendix 4A and 4B. 


\section{China Policies for Building Energy Efficiency}


2.1 The Evolution of Building Energy EfFiciency Policies ......................... 13

2.2 LAws, Rules AND Ministry-LEVEl REgulations...................................... 17

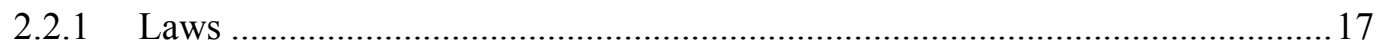

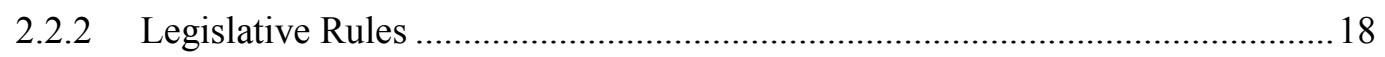

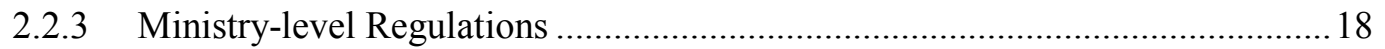

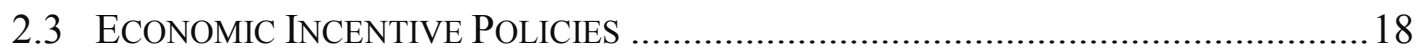

2.3.1 Residential Buildings in Severe Cold and Cold Regions ................................. 18

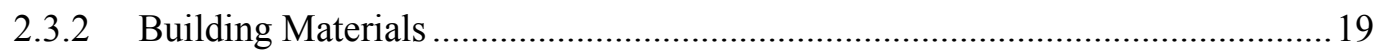

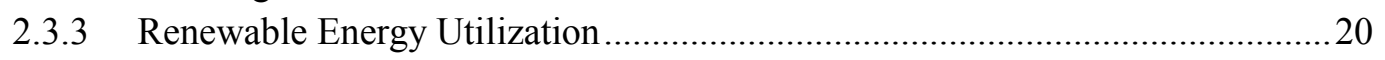

2.3.4 Governmental Office Building and Large-scale Public Buildings .....................20

2.4 OTHER IMPortant NATIONAL Policies ......................................................2 


\subsection{The Evolution of Building Energy Efficiency Policies}

In the late 1970s, China started an unprecedented economic reform, aiming to transform its Soviet Union-style planned economy into a hybrid of central planning and market economy. The development of building energy efficiency policies in China took place in the mid-1980s and evolved into five stages (Table 2-1).

Table 2-1 Key Policy Activities for China's Building Energy Efficiency

\begin{tabular}{|c|c|c|c|}
\hline Stages & Objectives & Dates & $\begin{array}{l}\text { Key Policy Activities } \\
\end{array}$ \\
\hline \multirow{3}{*}{ 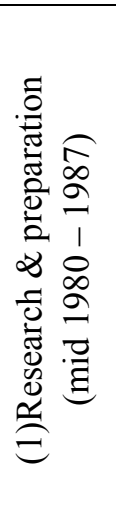 } & \multirow{3}{*}{$\begin{array}{l}\text { To investigate the } \\
\text { issues of building } \\
\text { energy efficiency, } \\
\text { and lay the } \\
\text { technical and } \\
\text { regulatory } \\
\text { foundation for } \\
\text { developing } \\
\text { projects and } \\
\text { policies in the } \\
\text { following stages }\end{array}$} & $\begin{array}{l}\text { Mid } \\
1980 s\end{array}$ & $\begin{array}{l}\text { China started to study residential building energy use } \\
\text { and prepare the development of relevant regulations and } \\
\text { technical standards. }\end{array}$ \\
\hline & & 1986 & $\begin{array}{l}\text { China released Energy Conservation Design Standard } \\
\text { for Residential Buildings in the Heating Zones (JGJ26- } \\
\text { 86), the first building energy codes in China. }\end{array}$ \\
\hline & & 1987 & $\begin{array}{l}\text { China issued a nation-wide notice to promote the } \\
\text { implementation of JGJ26-86. }\end{array}$ \\
\hline \multirow{5}{*}{ 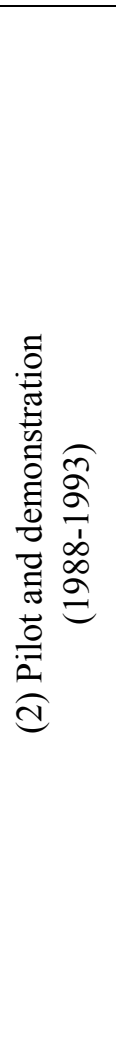 } & \multirow{5}{*}{$\begin{array}{l}\text { To test and } \\
\text { develop technical } \\
\text { standards and } \\
\text { collect information } \\
\text { for regulatory } \\
\text { development } \\
\text { related to building } \\
\text { energy efficiency }\end{array}$} & 1988 & $\begin{array}{l}\text { China released a nation-wide notice titled Opinion on } \\
\text { Accelerating Improvement of Wall Material and } \\
\text { Popularizing Building Energy Efficiency, and started } \\
\text { pilot projects in residential buildings of two cities. }\end{array}$ \\
\hline & & 1992 & $\begin{array}{l}\text { China expanded residential pilot projects to eight } \\
\text { provinces. Some local governments started to work on } \\
\text { large-scale pilot projects. }\end{array}$ \\
\hline & & 1990 & $\begin{array}{l}\text { China issued Lighting Design Standard for Civil } \\
\text { Building (GBJ133-90). }\end{array}$ \\
\hline & & 1991 & $\begin{array}{l}\text { China released Provisional Regulations for Investment } \\
\text { Orientation Regulatory Tax of Fixed Assets. }\end{array}$ \\
\hline & & 1993 & $\begin{array}{l}\text { China issued Building Thermal Technology of Tourist } \\
\text { Hotel and Energy efficiency Design Standard and } \\
\text { Regulation of Air Conditioner" (GB50189-93), an early } \\
\text { effort to promote building energy efficiency in } \\
\text { commercial buildings. } \\
\text { China issued Provisional Management of Imposing } \\
\text { Investment Orientation Regulatory Tax of the Fixed } \\
\text { Assets in the Northern Energy Efficiency Residential } \\
\text { Buildings. }\end{array}$ \\
\hline
\end{tabular}




\begin{tabular}{|c|c|c|c|}
\hline Stages & Objectives & Dates & Key Policy Activities \\
\hline \multirow{4}{*}{ 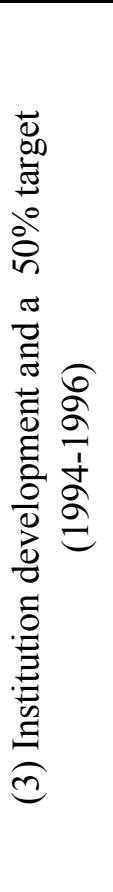 } & \multirow{4}{*}{$\begin{array}{l}\text { To develop the } \\
\text { institutional, technical, } \\
\text { and regulatory } \\
\text { framework for further } \\
\text { promotion of building } \\
\text { energy efficiency } \\
\text { nationwide, and to } \\
\text { develop a } 50 \% \text { target } \\
\text { for building energy } \\
\text { efficiency }\end{array}$} & 1994 & $\begin{array}{l}\text { The office of building energy efficiency was } \\
\text { established within Ministry of Construction to } \\
\text { coordinate the development and implementation } \\
\text { of building energy efficiency policies. }\end{array}$ \\
\hline & & 1995 & $\begin{array}{l}\text { The office developed China Building Energy } \\
\text { Efficiency for the Ninth Five-Year Plan (1996- } \\
\text { 2000) and the Plan in } 2010 \text { to set up goals and } \\
\text { implementation measures. }\end{array}$ \\
\hline & & 1995 & $\begin{array}{l}\text { China issued Energy Conservation Design } \\
\text { Standard for Residential Buildings in the } \\
\text { Heating Zones (JGJ26-95), an updated version } \\
\text { of JGJ26-86. JGJ26-95 first stated the 50\% } \\
\text { energy efficiency target. }\end{array}$ \\
\hline & & $\begin{array}{l}1994- \\
1996\end{array}$ & $\begin{array}{l}\text { China issued Policy on Building Energy } \\
\text { Efficiency Technology, and Policy on Building } \\
\text { Energy Efficiency Technology of Municipal and } \\
\text { other Public Buildings. }\end{array}$ \\
\hline \multirow{5}{*}{ 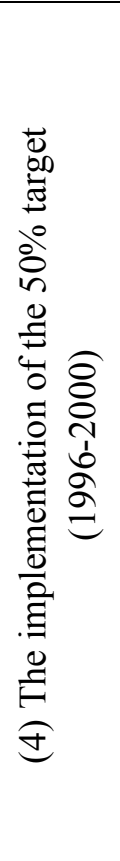 } & \multirow{5}{*}{$\begin{array}{l}\text { To implement the } 50 \% \\
\text { target nationwide }\end{array}$} & $\begin{array}{l}1996- \\
1997\end{array}$ & $\begin{array}{l}\text { The Chinese government issued a nation-wide } \\
\text { notice about the implementation of JGJ26-95. }\end{array}$ \\
\hline & & 1997 & $\begin{array}{l}\text { China issued Notice on Development and } \\
\text { Assessment of the Research Report of Feasibility } \\
\text { of Investment Project in Fixed Assets and stated } \\
\text { the importance of building energy efficiency in } \\
\text { its energy-efficiency Chapter. }\end{array}$ \\
\hline & & 1997 & $\begin{array}{l}\text { China's first energy conservation law was } \\
\text { released and later implemented in 1998. It } \\
\text { provided a critical regulatory support to promote } \\
\text { building energy efficiency in China. }\end{array}$ \\
\hline & & 1999 & $\begin{array}{l}\text { A national building energy efficiency conference } \\
\text { was held to discuss strategies to promote the } \\
\text { implementation of building energy efficiency. }\end{array}$ \\
\hline & & 2000 & $\begin{array}{l}\text { China issued Regulation of Energy Conservation } \\
\text { Management in Civil Building. }\end{array}$ \\
\hline
\end{tabular}




\begin{tabular}{|c|c|c|c|}
\hline Stages & Objectives & Dates & Key Policy Activities \\
\hline \multirow{5}{*}{ 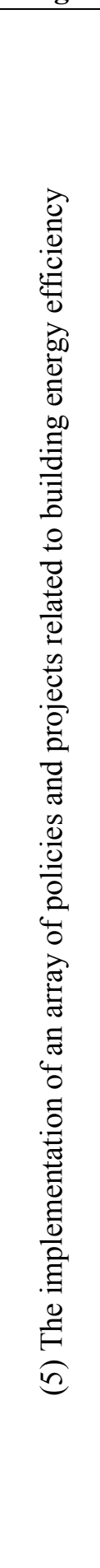 } & \multirow{5}{*}{ 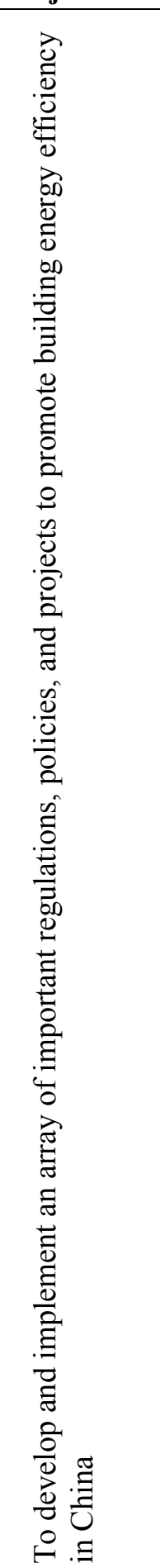 } & 2001 & $\begin{array}{l}\text { Design Standard for Energy Efficiency Inspection of } \\
\text { Heating Residential Buildings (JGJ 132-2001) and Design } \\
\text { Standard for Energy Efficiency in Residential Buildings in } \\
\text { the Hot Summer and Cold Winter Zone (JGJ134-2001) } \\
\text { were issued. }\end{array}$ \\
\hline & & 2002 & $\begin{array}{l}\text { China issued Outline of Eleventh- Five-year Plan (2006- } \\
\text { 2010) on Building Energy Efficiency, and stated that, } \\
\text { "reducing building energy consumption is an important } \\
\text { respect of carrying out sustainable development strategy, } \\
\text { and promoting the building energy efficiency actively is } \\
\text { important for developing construction industry and energy } \\
\text { efficiency." }\end{array}$ \\
\hline & & 2003 & $\begin{array}{l}\text { China issued Design Standard for Energy Efficiency in } \\
\text { Residential Buildings in the Hot Summer and Warm Winter } \\
\text { Zone (JGJ 75-2003). }\end{array}$ \\
\hline & & 2004 & $\begin{array}{l}\text { In the List of Technologies to be Popularized or Restrained } \\
\text { in Use, China listed external thermal insulation technology } \\
\text { for external walls, building doors and windows, and that the } \\
\text { heating energy-saving technology and solar energy } \\
\text { utilization were listed as preferable building technologies. } \\
\text { China issued Technological Outline of Construction } \\
\text { Industry. It stipulated that the design standards of building } \\
\text { energy efficiency should be strictly carried out in the } \\
\text { construction industry. } \\
\text { China issued China Medium and Long Term Energy } \\
\text { Conservation Plan, with specific goals for building energy } \\
\text { efficiency. }\end{array}$ \\
\hline & & 2005 & $\begin{array}{l}\text { China issued its Eleventh Five-Year Plan (2006-2010). } \\
\text { China issued Design Standard for Energy Efficiency in } \\
\text { Public Buildings (GB 50189-2005). } \\
\text { Operation Management Specification for Air-conditioning } \\
\text { and Ventilation Systems (GB50365-2005). It is China's first } \\
\text { specification about energy conservation operation of air } \\
\text { conditioning and ventilation. }\end{array}$ \\
\hline
\end{tabular}




\begin{tabular}{|c|c|c|c|}
\hline Stages & bjectives & Dates & Key Policy Activities \\
\hline \multirow{4}{*}{ 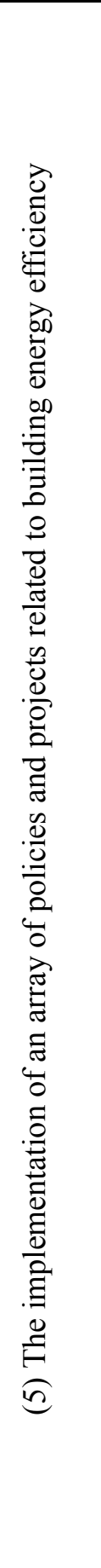 } & \multirow{4}{*}{ 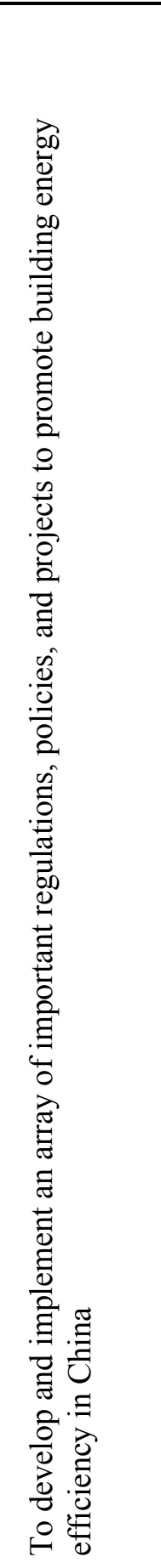 } & 2006 & $\begin{array}{l}\text { China issued the Renewable Energy Law. } \\
\text { China released Provisional Measures on the Management } \\
\text { of Special Fund Application for Renewable Energy } \\
\text { Building, with RMB } 104 \text { million (or US\$ } 13 \text { million }^{7} \text { ) } \\
\text { allocated to } 25 \text { awarded demonstration projects. } \\
\text { The Evaluation Standard for Green Building (GB/T50378- } \\
2006 \text { ) is the first grade evaluation standard for building } \\
\text { energy conservation. }\end{array}$ \\
\hline & & 2007 & $\begin{array}{l}\text { China issued Code for Acceptance of Engineering Quality } \\
\text { of Building Energy Conservation Project (GB50411-2007). } \\
\text { The updated China Energy Conservation Law was issued. } \\
\text { China released Interim Methods on Financial Reward } \\
\text { Management of Heat Measurement and Energy Efficiency } \\
\text { of Existing Building in the Northern Heating Areas, and } \\
\text { established a special fund of RMB } 900 \text { million (or US\$ } 123 \\
\text { million). } \\
\text { Provisional Measures on Management of Energy Efficiency } \\
\text { Special Fund for the Government Official Buildings and } \\
\text { Large-Scale Public Buildings. }\end{array}$ \\
\hline & & 2008 & $\begin{array}{l}\text { China issued the revised Regulation of Energy } \\
\text { Conservation Management in Civil Building. }\end{array}$ \\
\hline & & 2009 & $\begin{array}{l}\text { China issued Implementing Scheme for Utilizing Renewable } \\
\text { Energy in Buildings of Pilot Cities and Implementing } \\
\text { Scheme for Utilizing Renewable Energy in Building of } \\
\text { Rural Areas, with a special fund to subsidize the utilization } \\
\text { of renewable energy in buildings. } \\
\text { China issued Inspection Standards for Residential Building } \\
\text { Energy Efficiency (JGJ/T132-2001, 2009) and Inspection } \\
\text { Standards for Public Building Energy Efficiency } \\
\text { Conservation (JGJ/T177-2009). } \\
\text { Technical Specification for Energy Efficiency Renovation of } \\
\text { Public Building Energy Conservation (JGJ/T176-2009) is } \\
\text { China's first technical standard for energy efficiency } \\
\text { renovation in public buildings. }\end{array}$ \\
\hline
\end{tabular}

\footnotetext{
${ }^{7}$ The U.S. dollar value is converted based on the foreign exchange rate of the same year (Bank of China, 2011).
} 
The following two sections are focused on the introduction of laws, rules and regulations (Section 2.2), economic incentive policies (Section 2.3), and other important national policies related to building energy efficiency. Chapter 3 introduces another important policy instrument, building energy codes, which is the focus of the DOS project.

\subsection{Laws, Rules and Ministry-level Regulations}

China has established a legislative framework to promote building energy efficiency, including laws, legislative rules and ministry-level regulations.

\subsubsection{Laws}

Energy Conservation Law (1997, 2007), China's first major energy legislative milestone, was released in 1997 and implemented on January 1, 1998. It proclaimed that energy conservation is a long-term strategy for China's economic development. The law marked China's first significant legislative effort to regulate the rational use of energy resources, adjust the structure of energy use, improve energy efficiency and utilize renewable energy. Article 37 states that, "the design and construction of the building should be in accordance with relevant law and administrative regulation, adopt energy-efficient building structure, material, and products, improve the thermal and insulating performance, and reduce energy consumption in heating, refrigerating and lighting."

In order to reflect the new challenge of energy efficiency faced by the fastgrowing economy, the updated Energy Conservation Law was issued in 2007. Specifically, this updated version contains a separate section on building energy efficiency, with articles related to building energy codes such as administrative structure (Article 34), compliance and enforcement of building energy codes (Article $35)$, releasing energy information when selling houses by real estate development enterprises (Article 36), the implementation of indoor temperature control system in public buildings (Article 37), household heat metering system (Article 38), urban power conservation management for decorative landscape lighting in public facilities and large-scale buildings (Article 39), and building materials, solar and renewable energy (Article 40).

Renewable Energy Law (2006) has provisions on the use of renewable energy (such as solar energy) and heat pumps in buildings. The law offered a legislative basis to promote the use of renewable energy in buildings. 


\subsubsection{Legislative Rules}

In order to better interpret related provisions about building energy efficiency stated in Energy Conservation Law (2007), the State Council, China's chief administrative authority, issued Rule on Energy Conservation in Civil Building in 2008. This is China's first national administrative rule focused solely on building energy efficiency.

The rule states that the government needs to provide regulatory and economic incentive policies (such as taxes) to promote building energy efficiency. The rule requests that the inspection of building energy efficiency be carried out in all stages of the process (approval, design, construction, and operation) of a construction project. It also contains provisions on retrofits in existing buildings and the utilization of renewable energy in new and existing buildings.

\subsubsection{Ministry-level Regulations}

In order to implement Energy Conservation Law (1997) and the 50\% energy efficiency target stated in Energy Conservation Design Standard for Residential Buildings in the Heating Zones (JGJ26-95), the then Ministry of Construction (MOC) or the current Ministry of Housing and Urban-rural Development (MOHURD) issued Regulation of Energy Conservation Management in Civil Building in 2000.

The regulation was later revised and issued in 2006. It requires building energy efficiency management to cover the whole process of a construction project, including processes of approval, design, construction, project quality monitoring and operation. It also stated specific penalty measures for violations of mandatory provisions of building energy codes.

\subsection{Economic Incentive Policies}

Thanks to a series of governmental regulatory efforts in the mid to late 1980s, China made early progress in building energy efficiency. Since the 1990s, China has developed many economic incentive policies targeted at residential buildings in severe cold and cold regions (Section 2.3.1), building (wall) materials (Section 2.3.2), renewable energy utilization (Section 2.3.3), as well as governmental office buildings and large-scale public buildings (Section 2.3.4).

\subsubsection{Residential Buildings in Severe Cold and Cold Regions}

China released Provisional Regulations for Investment Orientation Regulatory Tax of Fixed Assets in 1991, utilizing tax policy to influence decision making of investment in fixed assets. The 1991 regulation issued a zero regulatory tax rate for 
energy efficient residential buildings in severe cold and cold regions. Two years later, Provisional Management of Imposing Investment Orientation Regulatory Tax of the Fixed Assets in the Northern Energy Efficiency Residential Buildings defined the energy-efficient residential buildings in severe cold and cold regions to be in compliance with Design Standard for Energy Efficiency of Residential Buildings in Severe Cold and Cold Zones (JGJ26-1986), and re-stated a zero regulatory tax rate for these buildings. Although this regulation was cancelled in $1999^{8}$, it helped guide investment of fixed assets to pursue building energy efficiency.

In 2007, the State Council issued an official notice about energy conservation and an emissions reduction plan. One of goals mentioned in the notice was to push heat reform and energy efficiency retrofits in the existing residential buildings of northern heating areas. In the same year, China released Interim Methods on Financial Reward Management of Heat Measurement and Energy Efficiency of Existing Building in the Northern Heating Areas, and established a special fund of RMB 900 million (or US\$ 123 million). The special fund was used to subsidize the installation of heat meters and energy efficient retrofits of residential buildings in northern heating areas.

\subsubsection{Building Materials}

China issued several tax incentives ${ }^{9}$ (such as zero income tax and zero valueadded tax) to encourage the production of new wall materials produced from the large gangue, slag, fly ash, and bottom dreg of coal fired boilers (excluding blast furnace water dreg).

In 2000, the State Council issued Notice on the Opinion of Accelerating Improvement of Wall Material and Popularizing Energy-Conservation Building, requiring the elimination of solid clay brick in municipalities, coastal cities and 170 cities which with fewer than 0.053 hectares per capita area of cultivated farmland before 2003. The provincial capital cities reached the goal of eliminating the solid clay brick by the end of 2005. In 2002, the Chinese government released Collection

\footnotetext{
${ }^{8}$ In order to promote economy development and encourage domestic demand, Chinese government issued Notice about Stopping Collecting Investment Orientation Regulatory Tax of the Fixed Assets in late 1999. The related tax policy associated to energy-efficient residential buildings in heating zones was cancelled, too.

${ }^{9}$ These tax incentives included zero income tax mentioned in Notices on Several Preferential Policies of Corporate Income Tax in 1994, zero value-added tax mentioned in Notice on the Opinion of Accelerating Improving Wall Material and Popularizing Building Energy-Conservation in 1992, and Notice about Zero Value-Added Tax on Some Resource Comprehensive Utilization Products in 1995, Notice about Questions of Value-Added Tax Policy on Some Resource Comprehensive Utilization and Other Products in 2001, and Supplementary Notice about Value-Added Tax Policy on Some Resource Comprehensive Utilization Products in 2004.
} 
and Usage Management of the Special Fund for New Wall Material, which clearly stipulated the collection target, criteria, procedure, supervision and inspection, and penalty for collecting the special fund to support new wall materials.

\subsubsection{Renewable Energy Utilization}

China released Provisional Measures on the Management of Special Fund Application for Renewable Energy Building in 2006, with RMB 104 million (or US\$ 13 million) allocated to 25 awarded demonstration projects. The objectives of this special fund were to promote the utilization of renewable energy in buildings and raise public awareness about energy conservation and renewable energy. The key sponsored technologies and products include solar water heating in buildings, photoelectricity exchange, lighting, ground source heat pumps, heat pumps with the shallow layer of underground water source for heating and refrigerating, utilizing fresh/sea water source heat pump technology for heating and refrigerating, and utilizing sewage source heat pump technology for heating and refrigerating.

In 2009, China issued Implementing Scheme for Utilizing Renewable Energy in Buildings of Pilot Cities and Implementing Scheme for Utilizing Renewable Energy in Building of Rural Areas, with a special fund to subsidize the utilization of renewable energy in buildings. A pilot city would receive RMB 50 million to 80 million (or US\$ 7 million or 12 million) if the building areas used renewable energy to reach a certain number of square meters within two years. A pilot county would receive a maximum RMB 18 million (or US\$ 3 million) if the rural building areas used renewable energy to reach a certain number of square meters.

In the same year, China released Provisional Means on Subsidizing Finance Management of the Solar Photo-Electricity in Building, and Implementing Opinions on Accelerating the Utilization of Solar Photo-Electricity in Building. Pilot cities and rural and remote areas would receive subsidies by promoting photo-electricity buildings. The subsidies helped solar electricity to be price competitive with electricity produced by thermal power plants.

\subsubsection{Governmental Office Building and Large-scale Public Buildings}

In 2007, China issued a series of regulations related to a special fund for supporting building energy efficiency in governmental office buildings and large-scale public buildings, including Provisional Measures on Management of Energy Efficiency Special Fund for the Government Official Buildings and Large-Scale Public Buildings, Notice on Provisional Measures on Management of Energy Efficiency Special Fund for the Government Official Buildings and Large-Scale 
Public Buildings and Implementation Suggestion on Strengthening Energy Efficiency Management of the Government Official Buildings and Large-Scale Public Buildings.

The central government would provide a discount loan to subsidize energy efficiency renovation projects implemented in government office buildings and largescale public buildings. The Chinese government paid 50\% interest on loans for local projects and paid all the interest for the central government's projects.

\subsection{Other Important National Policies ${ }^{10}$}

The National Development and Reform Commission (NDRC), the powerful administrative entity in charge of China's macroeconomic policies and development, issued the China Medium and Long Term Energy Conservation Plan in 2004. The Plan revealed ambitious energy conservation targets for Chinese buildings: "During the Eleventh Five-year Plan period, new buildings should strictly subject to the design standard of 50\% energy conservation. Several major cities such as Beijing and Tianjin shall take a lead in implementing the $65 \%$ energy-saving standard. Reform of heat supply system shall be carried out in a full scale. In China's large and medium cities, a charge system based on thermal meter will be widely spread in district heating of residential and public buildings; small cities will be pilot of such practice. Energy saving retrofit for existing residential and public buildings shall be conducted in combination with urban reconstruction. Large cities are expected to improve $25 \%$ of building areas, medium cities $15 \%$ and small cities $10 \% . "$

In 2005, the Chinese government called for building a resource conserving and environmentally friendly society in its Eleventh Five-Year Plan. This plan is widely regarded as the roadmap for China's social and economic development for 2006 to 2010. In this newest national plan, ten priority programs related to energy conservation have been identified for meeting the goals of reducing energy intensity and mitigating primary pollutants by $20 \%$ and $10 \%$, respectively, by the year 2010 , compared to the levels in 2005. Six of the ten priority programs are related to building energy efficiency, including (1) energy conservation in buildings, (2) energy efficient lighting, (3) energy conservation in governmental buildings and vehicles, (4) district heating and power generation, (5) recovery of residual heat and pressure, and (6) building the energy conservation monitoring and technological support system.

\footnotetext{
10 This section is based a PNNL report titled Country Report on Building Energy Codes in China (Shui et al, 2009).
} 


\section{China Building Energy Codes}




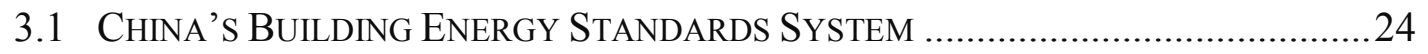

3.2 DESIGN StANDARDS FOR BUILDING ENERGY EFFICIENCY ..............................26

3.2.1 Development Priority for Design Standards..................................................26

3.2.2 Main Contents of Design Standards ...............................................................26

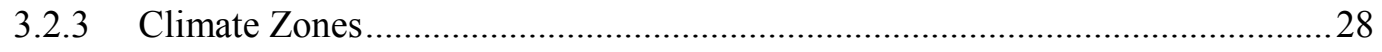

3.2.4 Design Standard for Energy Efficiency in Residential Buildings ......................28

Design Standard for Energy Efficiency of Residential Buildings in Severe Cold and Cold

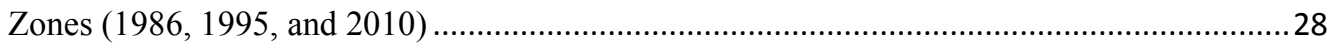

Design Standard for Energy Efficiency of Residential Buildings in Hot Summer and Cold

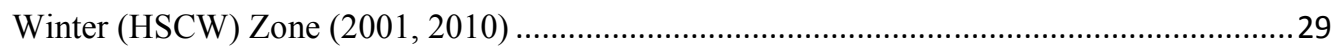

Design Standard for Energy Efficiency of Residential Buildings in Hot Summer and Warm

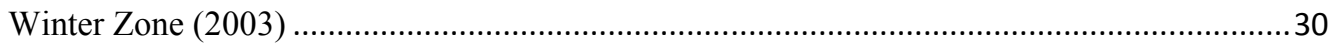

Design Standard for Energy Efficiency in Public Buildings …..................................... 31

3.3 CONSTRUCTION AND ACCEPTANCE STANDARD ................................................. 31 


\subsection{China's Building Energy Standards System}

Buildings in China are categorized into civil and industrial buildings. Civil buildings include residential and public buildings. Residential buildings mentioned in building energy codes refer to apartment buildings. Public buildings mentioned in building energy codes are non-residential civil buildings, including office buildings, schools, hospitals, hotels, and shopping buildings. The current building energy codes cover requirements for building energy efficiency in civil buildings.

After nearly three decades of effort, China has established a comprehensive building energy standards system. The system covers a building life cycle (design, construction and acceptance, inspection, evaluation, modification, operation, and products and building materials) (Figure 3-1).

Aiming to inspect the actual energy efficiency in buildings, China issued inspection standards for building energy efficiency: Inspection Standards for Residential Building Energy Efficiency (JGJ/T132-2001, 2009) and Inspection Standards for Public Building Energy Efficiency Conservation (JGJ/T177-2009). The inspection standards provide the basic technical requirements for energy efficiency inspection and regulate inspection methods and data for the assessment of building energy efficiency.

Technical Specification for Energy Efficiency Renovation of Public Building Energy Conservation (JGJ/T176-2009) is China's first technical standard for energy efficiency renovation in public buildings. It specifies the energy efficiency renovation process of public buildings. The Technical Specification includes diagnosis, judgment, renovation, and evaluation of energy conservation of a project. The renovated components include building envelope, HVAC, power supply and distribution system, monitoring and control systems, and utilization system of renewable energy.

The Evaluation Standard for Green Building (GB/T50378-2006) is the first rating evaluation standard for green building. It evaluates the rating of green building in connection with energy conservation, land conservation, water conservation, material conservation and environmental protection in the whole lifecycle of a building.

MOHURD issued Operation Management Specification for Air-conditioning and Ventilation Systems (GB50365-2005) in 2005, China's first specification for energy conserving operation of air conditioning and ventilation. 


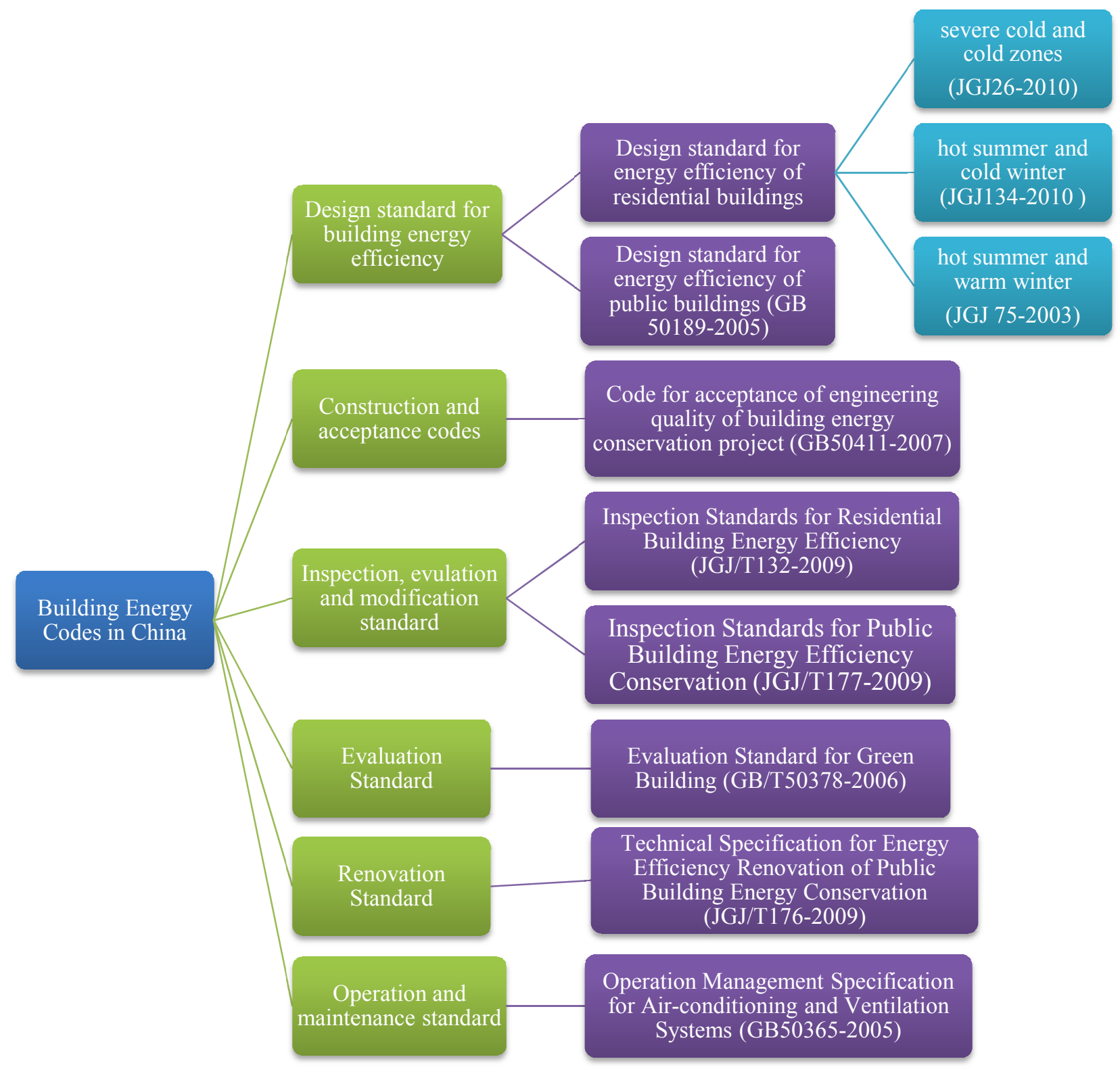

Figure 3-1 China's Building Energy Standards System

The DOS project is focused on three design standards for building energy efficiency of residential (JGJ26-2010 and JGJ134-2010) and public (GB50189-2005) buildings, as well as the Code for Acceptance (GB50411-2007). All four are referred to as China's building energy codes in this report, and are introduced in the following sections (Sections 3.2 and 3.3). 


\subsection{Design Standards for Building Energy Efficiency}

\subsubsection{Development Priority for Design Standards}

The development priority of building energy codes in China is on residential more than public buildings, in the northern part of China (or the heating zones) more than the south, and on new more than existing buildings (Lin 2008).

There are three reasons behind this development priority: (1) a fast growing housing market for residential buildings, (2) a significant share of residential energy compared to energy use of public buildings, (3) residential space heating in heating regions as the largest share of residential energy use.

In addition, China has had another un-stated development priority, which is to focus more on urban areas than rural areas. The current residential building energy codes apply to apartment buildings, while the most common residential building type in rural areas is low-rise residential housing or single homes.

\subsubsection{Main Contents of Design Standards}

The main contents of Chinese design standards are about the thermal performance of the building envelope and the energy efficiency of HVAC equipment and systems the two factors widely believed to have the greatest influence on building energy efficiency in China.

The current design standards in both residential and public buildings consist of a mixture of mandatory and prescriptive requirements, as well as performance-based approaches for thermal performance of the building envelope and energy requirements for HVAC systems.

The current design standards exclude other building components such as lighting, electric power and hot water systems. Lighting energy efficiency is covered in a separate lighting standard titled Standard for Lighting Design in Buildings (GB 50034-2004).

The structure difference between China's design standards and building energy codes in other APP countries is presented in Table 3-1. 
Table 3-1 Structure Comparison of Building Energy Codes in APP Countries

\begin{tabular}{|c|c|c|c|c|c|c|c|c|c|c|c|c|c|c|}
\hline \multirow{3}{*}{ Items } & \multicolumn{2}{|c|}{ Aus tralia } & \multicolumn{2}{|c|}{ Canada } & \multicolumn{4}{|c|}{ China } & \multirow{2}{*}{ India } & \multicolumn{2}{|c|}{ Japan } & \multirow{2}{*}{ Korea } & \multicolumn{2}{|c|}{ U.S. } \\
\hline & $\mathrm{C}$ & $\mathrm{R}$ & $\mathrm{C}$ & $\mathrm{R}$ & $\mathrm{C}$ & $\mathrm{R} 1$ & R2 & R3 & & & $\mathrm{R}^{*}$ & & $\mathrm{C}^{*}$ & $\mathrm{R}^{*}$ \\
\hline & \multicolumn{2}{|c|}{2007} & \multicolumn{2}{|c|}{1997} & 2005 & 2010 & 2010 & 2003 & 2007 & \multicolumn{2}{|c|}{1999} & 2008 & 2007 & 2009 \\
\hline Envelope & $\mathrm{X}$ & $\mathrm{X}$ & $\mathrm{X}$ & $\mathrm{X}$ & $\mathrm{X}$ & $\mathrm{X}$ & $\mathrm{X}$ & $\mathrm{X}$ & $\mathrm{X}$ & $\mathrm{X}$ & $\mathrm{X}$ & $\mathrm{X}$ & $X$ & $\mathrm{X}$ \\
\hline HVAC & $\bar{X}$ & $\mathrm{X}$ & $\mathrm{X}$ & $\bar{X}$ & $\mathrm{X}$ & $\mathrm{X}$ & $\mathrm{X}$ & $\mathrm{X}$ & $\mathrm{X}$ & $\mathrm{X}$ & $\mathrm{X}$ & $\mathrm{X}$ & $\mathrm{X}$ & $\mathrm{X}$ \\
\hline $\begin{array}{l}\text { Service Hot } \\
\text { Water and } \\
\text { Pumping }\end{array}$ & $\mathrm{X}$ & $\mathrm{X}$ & $\mathrm{X}$ & $\mathrm{X}$ & & & & & $\mathrm{X}$ & $X$ & $\mathrm{X}$ & $\mathrm{X}$ & $\mathrm{X}$ & $X$ \\
\hline Lighting & $\mathrm{X}$ & & $\mathrm{X}$ & $\mathrm{X}$ & [1] & & & & $\mathrm{X}$ & $\mathrm{X}$ & & $\mathrm{X}$ & $\mathrm{X}$ & $\mathrm{X}$ \\
\hline $\begin{array}{c}\text { Electrical } \\
\text { Power }\end{array}$ & $\mathrm{X}$ & & $\mathrm{X}$ & $\mathrm{X}$ & & & & & $\mathrm{X}$ & & & $\mathrm{X}$ & $X$ & \\
\hline $\begin{array}{l}\text { Trade-offs } \\
\text { and building } \\
\text { performance } \\
\text { approach }\end{array}$ & $\mathrm{X}$ & $\mathrm{X}$ & $\mathrm{X}$ & $\mathrm{X}$ & $\mathrm{X}$ & $\mathrm{X}$ & $\mathrm{X}$ & $\mathrm{X}$ & $\mathrm{X}$ & $X$ & $\mathrm{X}$ & $\mathrm{X}$ & $\mathrm{X}$ & $\mathrm{X}$ \\
\hline $\begin{array}{l}\text { Renewable } \\
\text { energy }\end{array}$ & $\mathrm{X}$ & $\mathrm{X}$ & $\mathrm{X}$ & $\mathrm{X}$ & & $\mathrm{X}$ & $\mathrm{X}$ & & $\mathrm{X}$ & $\mathrm{X}$ & & $\mathrm{X}$ & $\mathrm{X}$ & $X$ \\
\hline Others & & & & & & & & & & $\mathrm{X}$ & $\mathrm{X}$ & & & \\
\hline
\end{tabular}

Source: revised from Table 7 of Shaping the Energy Efficiency in New Buildings: A Comparison of Buildings Energy Codes in the Asia-Pacific Region (Evans, M., B. Shui, \& A. Delgado, 2009)

Note:

- $\quad \mathrm{C}=$ commercial buildings, $\mathrm{R}=$ residential buildings, $\mathrm{A}$ dark-gray colored cell indicates not applicable.

- $\quad$ 1] China has a separate code that covers lighting.

- China's R1 refers to Design Standard for Energy Efficiency of Residential Buildings in Severe Cold and Cold Zones (JGJ 26-2010), R2 refers to Design Standard for Energy Efficiency in Residential Buildings in the Hot Summer and Cold Winter Zone (JGJ134- 2010), and R3 refers to Design Standard for Energy Efficiency in Residential Buildings in the Hot Summer and Warm Winter Zone (JGJ 75-2003).

- Japan's R* refers to the structure integrated from two residential building energy codes: Criteria for Design and Construction Guidelines on the Rationalization of Energy Use for Houses and Clients on the Rationalization of Energy Use for Houses.

- U.S.' C* refers to ASHRAE 2007 and R* refers to IECC 2009.

- In most countries that mention renewable energy in their building energy codes, renewable energy is not required, per se, but using site-generated renewable energy provides exceptions to certain code requirements 


\subsubsection{Climate Zones}

China's climate varies from cold to tropical temperate and from mountainous to desert. Based on heating-degree days (HDD $18,{ }^{\circ} \mathrm{C} \cdot \mathrm{d}$ ) and cooling-degree days $\left(\mathrm{CDD} 26,{ }^{\circ} \mathrm{C} \cdot \mathrm{d}\right)$, China's building energy codes identify five climate zones across the country as presented in Figure 3-2: (1) severe cold, (2) cold, (3) hot summer and cold winter (HSCW), (4) hot summer and warm winter (HSWW), and (5) temperate.

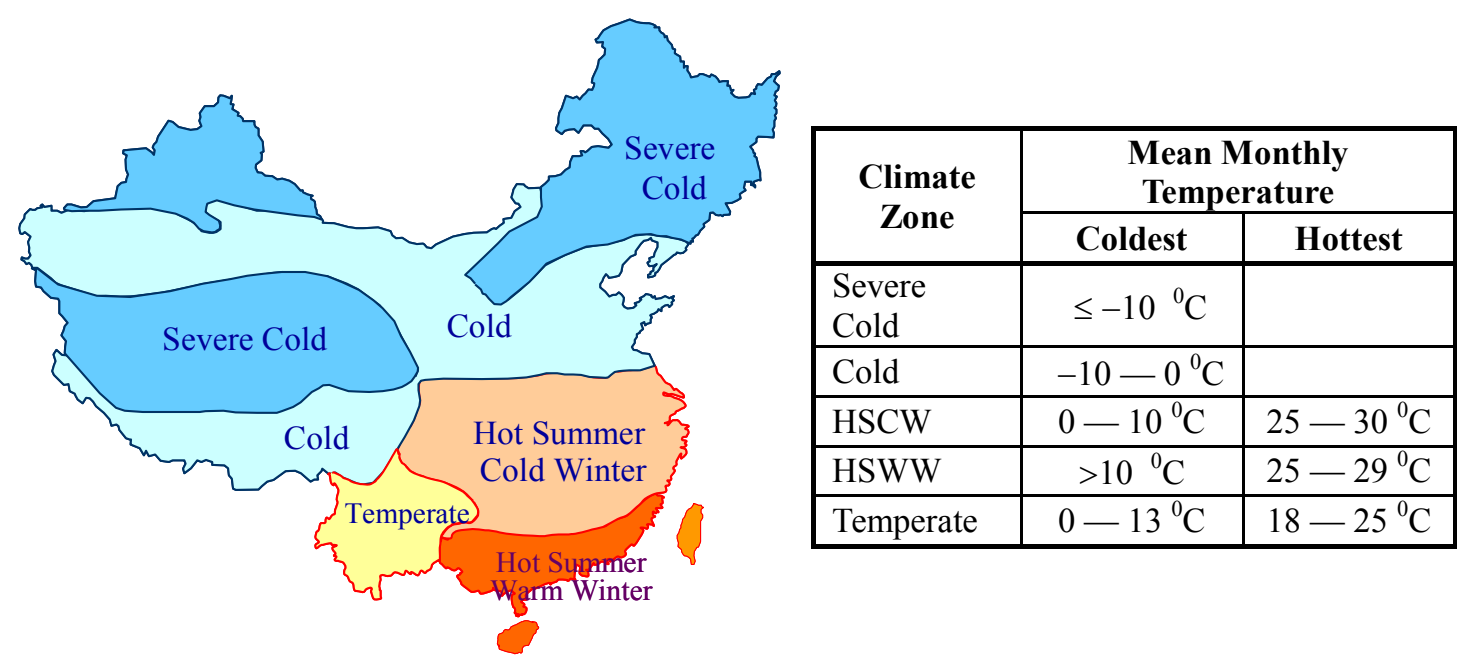

Figure 3-2 China's Climate Zones

\subsubsection{Design Standard for Energy Efficiency in Residential Buildings}

China has developed three national design standards for residential buildings in (1) the heating zone (including both severe cold and cold zones), (2) the HSCS zone and (3) the HSWW zone. All three standards apply to the energy efficient design of new construction, additions and retrofits of existing residential buildings.

\section{Design Standard for Energy Efficiency of Residential Buildings in Severe Cold and Cold} Zones (1986, 1995, and 2010)

In the severe cold and cold zones, space heating is the predominant energy end use for buildings. In 1986, China released its first building energy code, entitled the Energy Conservation Design Standard for Residential Buildings in the Heating Zones (JGJ 26-86), in an effort to reduce energy use of space heating and improve indoor thermal comfort in heating regions. The standard was later updated and released in 1995 and required residential buildings to be approximately 50\% more efficient than 
residential buildings built in the early 1980 s, compared to $30 \%$ mentioned in the 1986 version.

In 2010, China issued the updated version titled Design Standard for Energy Efficiency of Residential Buildings in Severe Cold and Cold Zones (JGJ 26-2010). The 2010 version requires that residential buildings to be $65 \%$ more efficient than residential buildings built in the 1980s. Other highlights in the 2010 version include the following:

1) Based on the HDD and CDD index, the severe cold and cold climate zones are further divided into five smaller zones. The thermal performance of the building envelope is described by these five climate subzones. The breakdown of climate zones aims to tailor the regional thermal performance of the building envelope.

2) The technical content of this standard has a wider coverage compared to the 1995 version. Besides newly added thermal performance of building envelope by five climate subzones, the 2010 version added content about heating sources, a heating plant and heat supply network, a transmission and distribution (T\&D) system, and a monitoring and control system.

3) The 2010 version adds content about control and measurement for heating systems. It also regulates the control and measurement methods of heating systems.

4) Unlike previous versions, the 2010 version attaches calculation software for thermal performance, and adds a rather comprehensive description of calculation methodology and related parameters in its appendices.

The outline of Design Standard for Energy Efficiency of Residential Buildings in Severe Cold and Cold Zones (JGJ 26-2010) is presented in Appendix 1A.

\section{Design Standard for Energy Efficiency of Residential Buildings in Hot Summer and Cold Winter (HSCW) Zone (2001, 2010)}

China's economy has entered into a fast-growing stage since the mid 1990s, experiencing a soaring energy demand for air conditioning and space heating in the HSCW and HSWW zones (Huang and Deringer 2007), two regions with China's highest population density and intensive industrial activities.

In 2001, China issued its first residential building energy codes for the HSCW zone, Design Standard for Energy Efficiency in Residential Buildings in the Hot Summer and Cold Winter Zone (JGJ 134-2001). The 2001 version required annual 
energy consumption of a new building to be 50\% more energy efficient than those built in earlier in the 1980s.

In 2010, China issued the updated version, titled Design Standard for Energy Efficiency of Residential Buildings in Hot Summer and Cold Winter Zone (JGJ1342010). Contrary to the assumption of many people, the 2010 version does not require the thermal performance requirements of building envelope and energy efficiency of HVAC to be $65 \%$ more efficient than residential buildings built in the 1980 s, as Design Standard for Energy Efficiency of Residential Buildings in Severe Cold and Cold Zones (JGJ 26-2010) did. The code developers believed that the effective implementation of the $50 \%$ target is more important and should be addressed in this version, considering the current regional conditions and technology level. Other highlights in the 2010 version include the following:

1) The 2010 version updates thermal performance of the building envelope and includes updated requirements for energy efficiency of HVAC performance.

2) The 2010 version updates a new trade-off approach to evaluate thermal performance of building envelopes with more details about application conditions and parameter settings, which clarified many common confusions raised after the release of the 2001 version.

3) The technical content of this standard has a wider coverage compared to the 2001 version, adding content related to heating and cooling sources, T\&D systems, and monitoring and control systems.

4) The 2010 version introduces design requirements for a geothermal pump system, encouraging the use of renewable energy and waste energy for heating and cooling.

The outline of Design Standard for Energy Efficiency in Residential Buildings in the Hot Summer and Cold Winter Zone (JGJ134-2010) is presented in Appendix 1B.

\section{Design Standard for Energy Efficiency of Residential Buildings in Hot Summer and Warm Winter Zone (2003)}

China issued Design Standard for Energy Efficiency in Residential Buildings in the Hot Summer and Warm Winter Zone (JGJ 75-2003) in 2003. In this standard, the HSWW zone is divided into two sub regions: the north sub region (for both cooling and heating) and the south sub region (for cooling only). This standard aims to reduce annual energy consumption of HVAC by $50 \%$, compared to buildings without a measurement of energy saving, with a mixture of mandatory and voluntary provisions related to thermal performance of building envelopes and energy performance of 
HVAC. China is currently revising Design Standard for Residential Building Energy Conservation in Areas Warm in Winter and Hot in Summer.

The outline of JGJ 75-2003 Design Standard for Energy Efficiency in Residential Buildings in the Hot Summer and Warm Winter Zone is presented in Appendix 1C.

\section{Design Standard for Energy Efficiency in Public Buildings}

Public buildings in China's building energy codes refer to non-residential civil buildings, including hotels, schools, commercial, educational and governmental buildings. China published Design Standard for Energy Efficiency in Public Buildings (GB 50189-2005) in 2005, the first building energy code for public buildings in general.

This standard focuses on the energy efficient design of new construction, additions to and retrofits of existing public buildings. The purpose of the standard is to reduce the annual energy consumption of new buildings by $50 \%$ compared to buildings of the early 1980s. The standard addresses the efficiency of the building envelope and HVAC systems with both mandatory and voluntary provisions.

Although the standard provides thermal performance requirement of the building envelop by climate zones, the standard does not distinguish thermal performance indicators and other energy efficiency measurement and performance by building classification. The homogenous indicators and requirements are regarded as the main shortcoming of this standard. There have been discussions about updating the 2005 version.

The outline of Design Standard for Energy Efficiency in Public Buildings (GB 50189-2005) is presented in Appendix 2.

\subsection{Construction and Acceptance Standard}

The implementation of design standards for building energy efficiency in the construction stage is the key to improving building energy efficiency in China. In 2007, MOHURD issued Code for Acceptance of Engineering Quality of Building Energy Conservation Project (GB50411-2007) to enhance building energy efficiency during the building construction and acceptance stage.

The Code for Acceptance requires that compliance with building energy efficiency requirements is mandatory for final acceptance of a building project, and states that, "the final acceptance of construction of the unit project will go on after 
qualified acceptance of building energy-conservation subsection, the building energyconservation project should construct according to qualified acceptance of design file and construction scheme." The release of the Code for Acceptance is a significant regulatory effort to enforce building energy codes in China

The Code for Acceptance, which has more than 70 pages, emphasizes four issues in the construction and acceptance stage: (1) the compliance of building design documents for energy efficiency, (2) quality of building materials and equipment on site, (3) construction quality control, and (4) system debugging and operation testing. It provides details on issues like how to check if exterior insulation materials have bonded to the wall correctly, the parts of the HVAC system that need to be inspected and how, and what on-site tests need to be done to ensure compliance. For each item in the Code, there is a description of the item, a list of the specifications that item must meet, a brief description of the inspection method and how many items must be inspected (typically from 5 to $100 \%$ of total quantity in a building) (Evans, Shui, \& Delgado, 2010).

The outline of Code for Acceptance of Engineering Quality of Building Energy Conservation Project (GB50411-2007) is presented in Appendix 3. 


\section{The Current Implementation of Building Energy Codes in China}




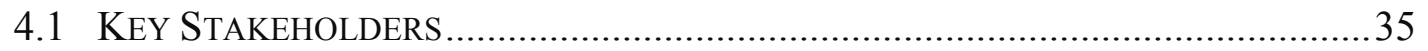

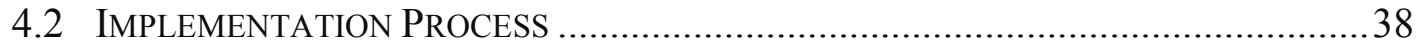

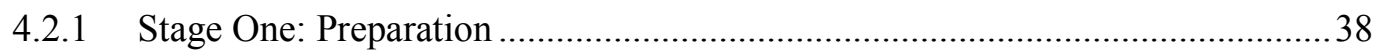

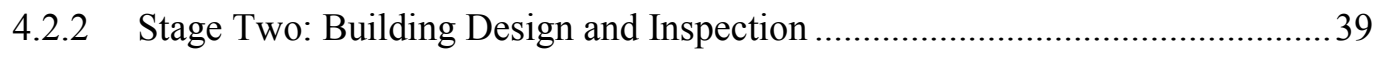

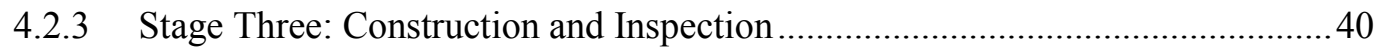

4.2.4 Stage Four: Construction Completion ........................................................... 41

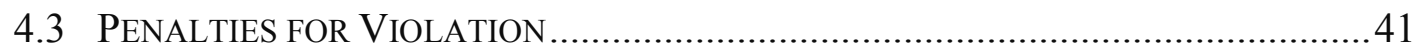

4.4 ANNUAL NATIONAL InSPECTION FOR BUILDING ENERGY EFFICIENCY .............42

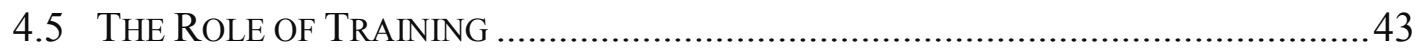

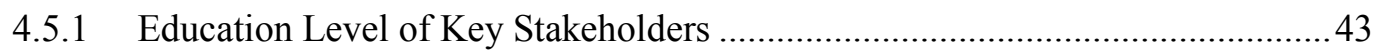

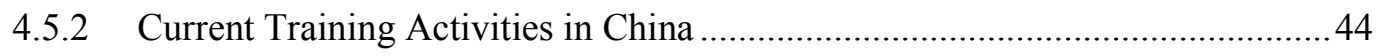

4.6 ImPlementation in Urban, Suburban and Rural AREAS........................45 
Enforcement of building energy standards has historically been problematic in China. Compliance is much better in developed regions, major cities like Beijing and Shanghai, and in the north, while it is less satisfactory in less developed regions, smaller cities and towns, and in the south. Compliance is often better at the design stage than in actual construction, which highlights the importance of inspections.

In the recent years, China has dramatically improved its enforcement system of building energy codes. These changes and the way the enforcement system works, however, have not been widely documented and analyzed (Evans et al. 2010). This chapter presents information collected from the project activities (such as discussion with national and local stakeholders, as well as focus group meetings), aiming to help better understand the implementation issues of China's building energy codes.

This chapter includes an introduction of key stakeholders (Section 4.2), implementation process (Section 4.3), the roles of national inspection for building energy efficiency (Section 4.4) and training (Section 4.5). A brief review of the implementation issues of APP countries, focused on the enforcement framework and training and information dissemination, is presented in Appendix 4A and 4B.

\subsection{Key Stakeholders}

The current implementation of building energy codes in China involves key stakeholders at both the national and local level (Figure 4-1).

At the national level, MOHURD coordinates and supervises the development and implementation of China's national building energy codes. CABR is the chief developer of nearly all of China's national building energy codes. On behalf of MOHURD, CABR is responsible for interpreting and maintaining China's building energy codes, as well as providing national training.

At the local level, local governmental agencies, building research entities, and an array of third parties interact in the building construction process and code enforcement.

Local construction administration departments, which report to both the city governments and to the provincial branches of MOHURD, are in charge of day-to-day enforcement activities, such as granting building permits and promoting the enforcement of building energy codes. Some cities can decide if they want to adopt national standards or develop their own, and the developed local codes are supposed to be better localized and more stringent than the national standards. The decisions made are based on the local government's commitment to advancing building energy 
efficiency, and are supported by the city's financial and technical resources. For example, Changchun and Ningbo have developed their own local design standards for building energy efficiency in residential buildings.

Local quality supervision stations are assessed and certified by the provincial administrative departments. The stations, which act as governmental monitoring agencies, are in charge of construction quality control and supervising work quality of third parties. Quality supervision stations are semi-governmental agencies and are paid for by the city government. Their activities include inspecting the building during key construction phrases and collecting, reviewing, and approving documents related to construction and code compliance. In Ningbo, the quality supervision and testing station has 40-50 staff, 3-5 of whom have detailed energy expertise (for example, heating engineers).

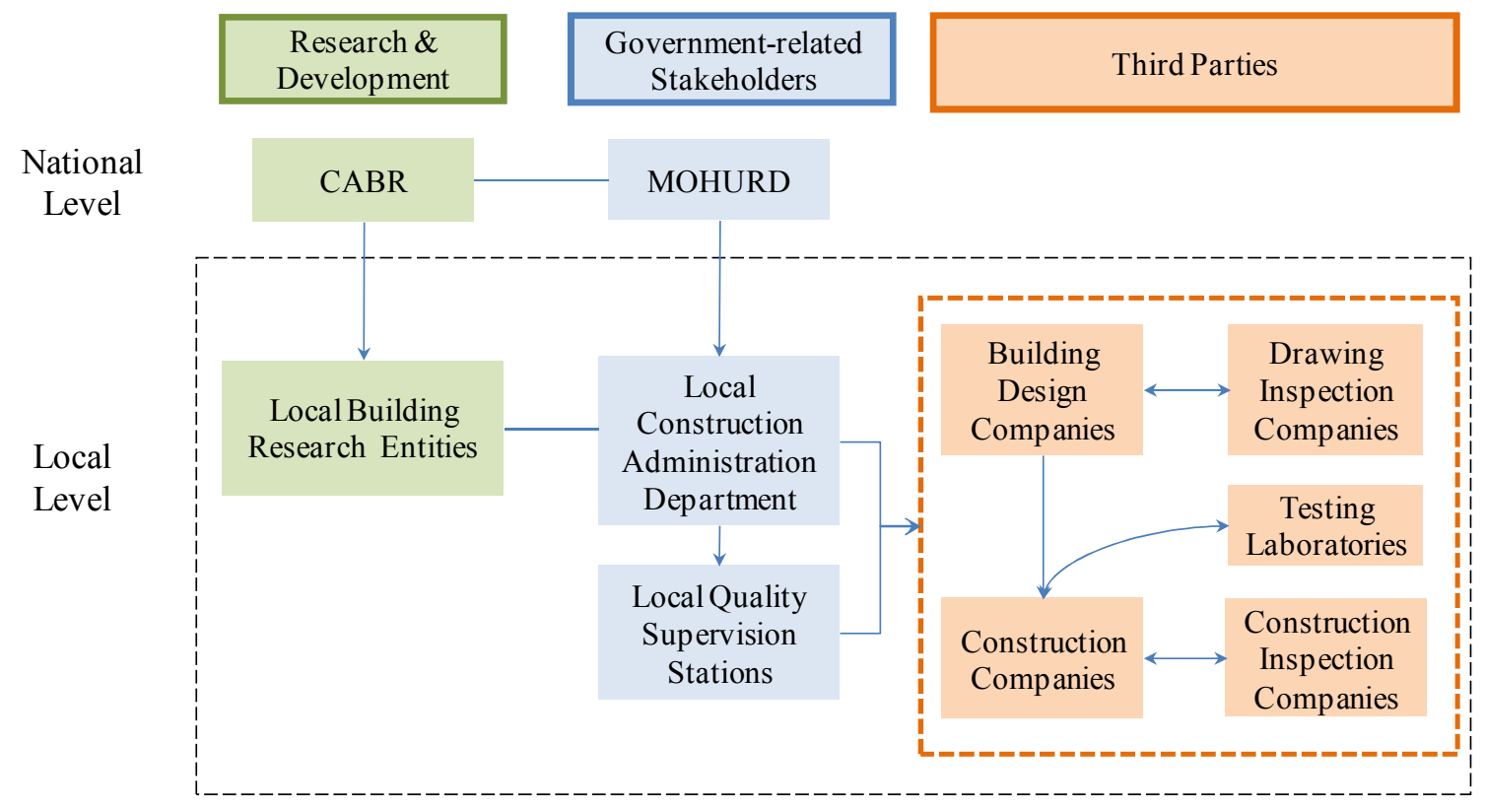

Figure 4-1 Key Stakeholders in the Implementation of Building Energy Codes in China

Local third parties are the core compliance implementers, which include building design companies, drawing inspection companies, construction companies, construction inspection companies, and testing companies and labs. They are hired by a developer through a bidding process and work for the developer to construct a building that complies with adopted building codes. Table 4-1 presents their major responsibilities and related information. 
Table 4-1 Role of Third Parties in the Implementation of Building Energy Codes

\begin{tabular}{|c|c|c|c|}
\hline Third party & Responsibilities & Decision Factors* & Other remarks \\
\hline $\begin{array}{l}\text { Building } \\
\text { design } \\
\text { companies }\end{array}$ & $\begin{array}{l}\text { Design buildings } \\
\text { in accordance } \\
\text { with a series of } \\
\text { design codes } \\
\text { (including the } \\
\text { design codes for } \\
\text { building energy } \\
\text { efficiency) and to } \\
\text { meet developer } \\
\text { requirements. }\end{array}$ & $\begin{array}{l}\text { - Understanding and } \\
\text { integrating the requirements } \\
\text { of design standards of } \\
\text { building energy efficiency } \\
\text { into building design, } \\
\text { - Meeting the cost } \\
\text { requirements set by hiring } \\
\text { developers; } \\
\text { - Utilizing new materials and } \\
\text { technology in the building } \\
\text { design to meet or exceed the } \\
\text { building energy efficiency } \\
\text { requirements, } \\
\text { - Having flexibility in } \\
\text { applying design standards. }\end{array}$ & $\begin{array}{l}\text { - The companies } \\
\text { consist of architects } \\
\text { and engineers. }\end{array}$ \\
\hline $\begin{array}{l}\text { Drawing } \\
\text { inspection } \\
\text { companies }\end{array}$ & $\begin{array}{l}\text { Verify the } \\
\text { building drawing } \\
\text { according to } \\
\text { design standards. }\end{array}$ & $\begin{array}{l}\text { Design drawings are in line } \\
\text { with a series of national } \\
\text { policies and regulations } \\
\text { related to buildings, as well } \\
\text { as the mandatory } \\
\text { requirements of building } \\
\text { standards and codes, such as } \\
\text { fire safety and energy } \\
\text { efficiency requirements. }\end{array}$ & $\begin{array}{l}\text { The companies } \\
\text { consist of senior } \\
\text { building designers } \\
\text { previously hired by } \\
\text { or retired from } \\
\text { building research } \\
\text { entities or building } \\
\text { design companies. }\end{array}$ \\
\hline $\begin{array}{l}\text { Construction } \\
\text { companies }\end{array}$ & $\begin{array}{l}\text { Construct a } \\
\text { building by } \\
\text { following the } \\
\text { approved building } \\
\text { drawing design } \\
\text { and the Code for } \\
\text { Acceptance. }\end{array}$ & $\begin{array}{l}\text { - The whole construction } \\
\text { process meets the Code for } \\
\text { Acceptance, } \\
\text { - Project cost control, } \\
\text { - Durability of building } \\
\text { materials meets engineering } \\
\text { requirements, } \\
\text { - Construction quality meets } \\
\text { the requirements of both } \\
\text { codes and developers. }\end{array}$ & $\begin{array}{l}\text { - During our site visit } \\
\text { to a construction site } \\
\text { in } 2009 \text {, we found } \\
\text { that the construction } \\
\text { company followed a } \\
\text { strict quality control } \\
\text { process to make sure } \\
\text { construction } \\
\text { complied with code } \\
\text { requirements. }\end{array}$ \\
\hline $\begin{array}{l}\text { Construction } \\
\text { inspection } \\
\text { companies }\end{array}$ & $\begin{array}{l}\text { Supervise the } \\
\text { construction } \\
\text { quality, monitor } \\
\text { the construction } \\
\text { process, and } \\
\text { control } \\
\text { construction } \\
\text { costs. }\end{array}$ & $\begin{array}{l}\text { - A construction process } \\
\text { meets the requirements of } \\
\text { the Code for Acceptance, } \\
\text { and } \\
\text { - A construction project is } \\
\text { completed on time and } \\
\text { within budget. }\end{array}$ & $\begin{array}{l}\text { - The companies are } \\
\text { independent from } \\
\text { construction } \\
\text { companies. } \\
\text { - The companies send } \\
\text { their staff to conduct } \\
\text { on-site inspections } \\
\text { through the } \\
\text { construction phrases. }\end{array}$ \\
\hline
\end{tabular}




\begin{tabular}{|c|c|c|c|}
\hline Third party & Responsibilities & Decision Factors* & Other remarks \\
\hline $\begin{array}{l}\text { Testing } \\
\text { companies } \\
\text { and labs }\end{array}$ & $\begin{array}{l}\text { Help test building } \\
\text { materials sent by } \\
\text { construction } \\
\text { companies and } \\
\text { manufacturers, } \\
\text { according to the Code } \\
\text { for Acceptance. }\end{array}$ & $\begin{array}{l}\text { Whether the performance } \\
\text { parameters of equipment } \\
\text { and building materials } \\
\text { meet the requirements as } \\
\text { defined by the acceptance } \\
\text { codes; and } \\
\text { - Whether a construction } \\
\text { project meets the } \\
\text { requirements set by the } \\
\text { acceptance codes. }\end{array}$ & $\begin{array}{l}\text { - The companies and } \\
\text { labs consist of } \\
\text { engineers and } \\
\text { technicians. } \\
\text { - Test companies are } \\
\text { often located in } \\
\text { urban areas or } \\
\text { neighboring areas. }\end{array}$ \\
\hline
\end{tabular}

Note: The information of decision factors were collected from focus group meetings in Changchun and Ningbo, August 2010.

Local building research entities, some of which are related to CABR, provide strong technical support not only to local construction administration departments, but also to other key stakeholders. For example, some local building research entities can be hired by a developer to provide building design service.

\subsection{Implementation Process}

Starting with the Tenth Five-Year Plan (2001 to 2005), China has established a set of supervising and monitoring approaches to enforce the implementation of building energy codes in the following four stages: (1) preparation, (2) building design and inspection, (3) construction and inspection, (4) completion (Figure 4-2).

\subsubsection{Stage One: Preparation}

A developer needs to submit an application to a local urban and rural planning department for a construction permit. The local urban and rural planning department shall coordinate with a local construction administration department to make sure the proposed construction plan meets building energy codes.

Once approved, the developer needs to hire a building design company, a drawing inspection company, a construction company, and a construction inspection company through a bidding process. These hired third parties should have qualified licenses for operation.

The quality supervision station verifies the bidding process and qualification of hired third parties. 


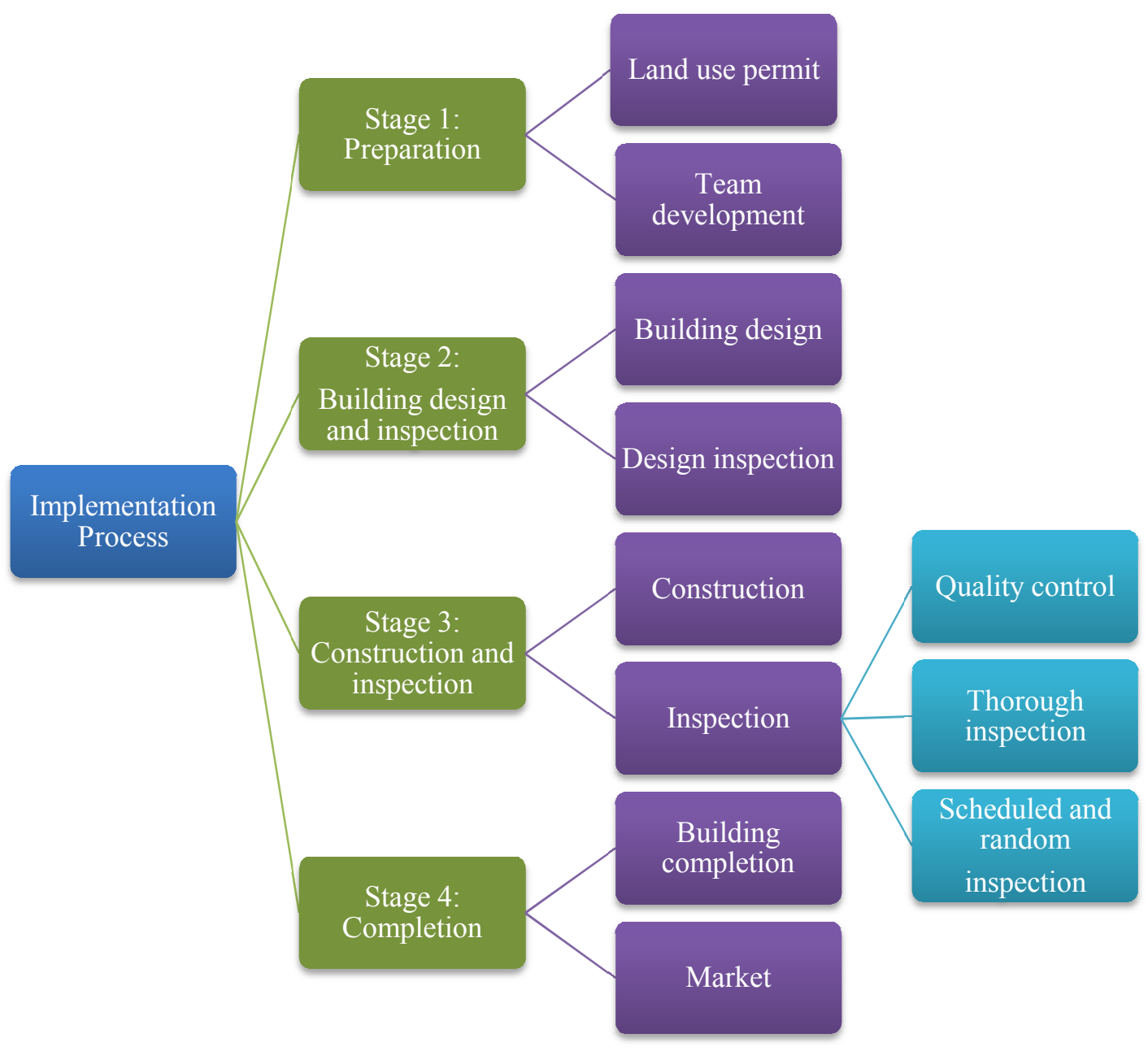

Figure 4-2 The Implementation Process of Building Energy Codes in China

\subsubsection{Stage Two: Building Design and Inspection}

The hired building design company works on building drawing and design. Once finished, the hired drawing inspection company needs to check and make sure if the drawing complies with related building codes (such as building structure, fire safety, earthquake resistance, building energy efficiency). Both parties employ building design software for their work. Appendix 5 presents a quick review about the current building software in China. 
The drawing inspection company will send the inspection report to the developer and the quality supervision station. After the verification of the quality supervision station, the construction administration department issues permission for construction.

\subsubsection{Stage Three: Construction and Inspection}

The developer submits a construction and compliance plan to the quality supervision station. Once approved, construction begins. Three inspection processes are implemented to ensure the enforcement of building energy codes: (1) quality control of the construction company, (2) thorough inspection by the construction inspection company, and (3) scheduled and random inspections by the quality supervision station.

\section{Quality control of the construction company}

The construction company has a quality control system and process in place. The quality supervision station review and approves the construction company's quality control protocols during the construction permitting process.

\section{Thorough inspection by the construction inspection company}

The construction inspection company conducts thorough inspections during the full construction process. The company sends its staff on site to oversee the construction work and ensure that the construction matches the building design and complies with building codes (such as the Code for Acceptance).

PNNL staff visited a construction site in Changchun in 2009: for four large apartment buildings under construction, there were thirteen staff members from the construction inspection company at the site and eight of them remained there through all the work days. The construction inspection staff monitors the construction and orders a series of tests to ensure the quality of the construction. When they spot a flaw in construction, the staff can order changes, ranging from completely redoing a portion of the construction to more minor changes, depending on the particular problem.

\section{Scheduled and random inspection by the quality supervision station}

The quality supervision station conducts both scheduled and random inspections, and at a minimum they will be on site for the pouring of the foundation, completion of the main structure, and before finalization of the building construction. When work is not properly done, the station can issue stop work orders and require revisions. 


\subsubsection{Stage Four: Construction Completion}

Once construction is complete, the quality supervision station should check if the construction, tests and related documents follow the mandatory requirement of building energy codes and the Code for Acceptance, and then prepare a completion report if there is compliance.

The developer takes this paperwork to the local construction administration department to apply for an occupancy permit.

With the occupancy permit, the developer can sell, rent or occupy the building. When this new building is on the market for sale, the seller, which could be a real estate company, needs to present consumers with information on the building's energy consumption indicators, building energy efficiency measures, and the guarantee period of thermal protection.

During the guarantee period, the construction company shall provide service to solve any quality-related problems, and provide financial compensation if any damage is caused.

\subsection{Penalties for Violation}

The Regulation of Energy Conservation and Management in Civil Building (2006) provides specific provisions about restricted incentives or penalties for violations by the building developer, building design companies, and construction companies.

If a building developer (1) revises energy conservation design files without authorization, or (2) expresses or implies to the building designing company and/or construction company about a violation of mandatory provisions of building energy codes, the developer shall be imposed a fine between RMB $200 \mathrm{~K}\left(\mathrm{US} \$ 30 \mathrm{~K}^{11}\right.$ ) to RMB 500K (US\$76K).

If a building design company did not follow mandatory provisions of building energy codes to design buildings, the company should revise the design. If the design company fails to do so, the company shall be warned and fined between RMB $100 \mathrm{~K}$ (US\$ $15 \mathrm{~K}$ ) to RMB 300K (US\$46K). Those building design companies with three projects not designed according to the mandatory provisions of building energy codes in two years shall be suspended until rectification, and their qualification certificates should be downgraded or revoked.

\footnotetext{
${ }^{11}$ The US dollar is converted with the foreign exchange rate in 2011.
} 
If a construction company fails to construct a project according to building energy efficiency design, the company should be ordered to correct the problems. Expenses for the rectification of a project are charged to the construction company. A disciplinary warning may be imposed, but for serious violations, a fine of between $2 \%$ and $4 \%$ of the construction contract cost shall be imposed. Those construction companies with three projects violated in two years shall be suspended until rectification, and their qualification certificates shall be downgraded or revoked.

\subsection{Annual National Inspection for Building Energy Efficiency}

In order to enforce the implementation of building energy efficiency, MOHURD has organized an annual nationwide inspection of building energy efficiency since 2005. For example, the national inspection in 2008 involved travelling to 55 large Chinese cities, including provincial capitals, four municipalities (such as Beijing and Shanghai), and five sub-provincial cities (such as Ningbo and Qingdao) (Shui et al. 2009).

MOHURD usually sends nine or ten survey teams in the fourth quarter of each year. MOHURD sends a notice about the survey, which lasts about one month, to the selected cities two weeks before the survey is scheduled to take place.

The inspection is focused on the implementation of relevant policies and regulations of building energy efficiency, training, and administration supervision. Among them, the implementation of building energy codes (especially for the mandatory provisions) is the main subject that is inspected. The selected cities are required to provide a complete inventory of the building projects submitted since the last survey. The survey team will randomly inspect twelve projects. Of these, it will examine building design drawings for six projects (including four public building projects and two residential building projects). For the remaining six, the survey team will conduct on-site inspections of the construction.

The inspection results are scored and sorted from high to low. The work teams will send notices for compliance violations to failed projects, and the problems should be fixed. Some provinces and cities, such as Zhejiang and Ningbo, have conducted several provincial-level and city-level inspections of the enforcement of building energy codes since 2005. Between 2005 and 2008, the compliance rates at the design and construction stage have been improved from $53 \%$ and $21 \%$ in 2005 to $98 \%$ and $82 \%$ in 2008 , respectively (Figure $4-3$ ). 


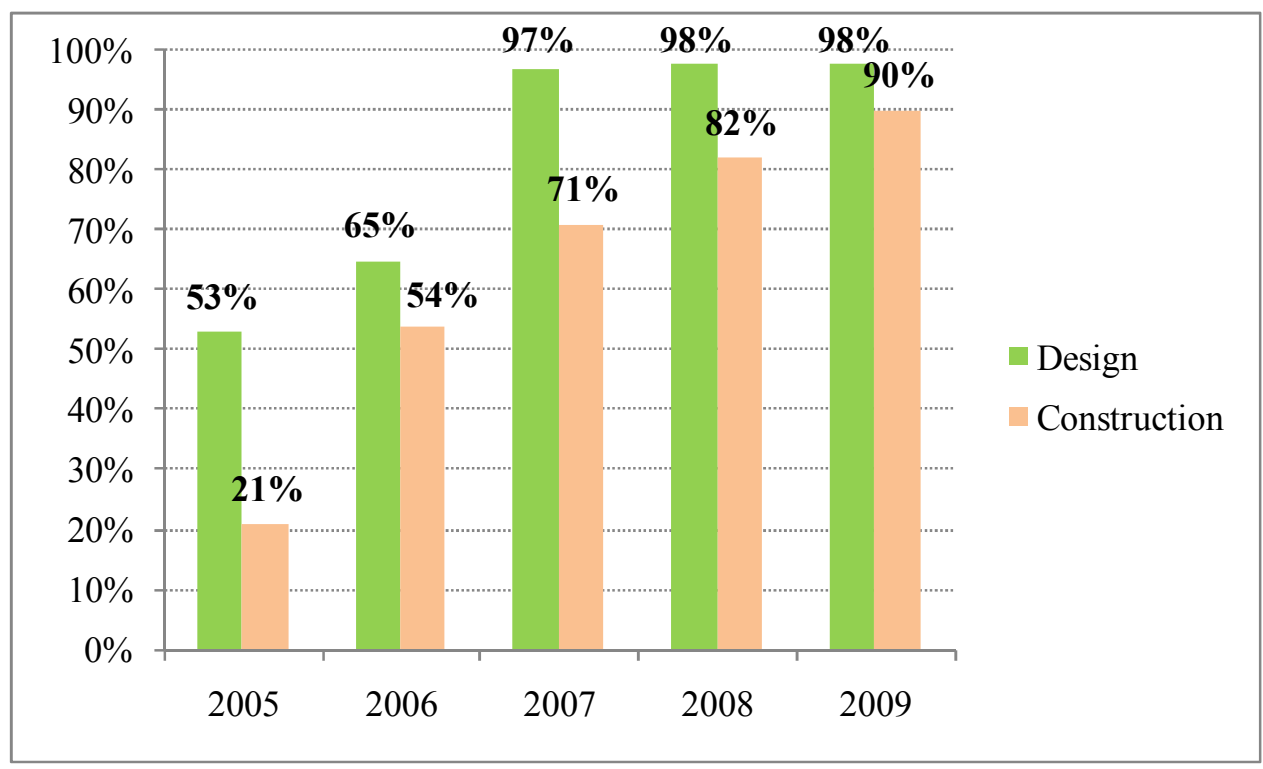

Figure 4-3 The Compliance Rate of Building Energy Codes in China in Cities Conducted the National Inspection, 2005 to 2008

\subsection{The Role of Training}

\subsubsection{Education Level of Key Stakeholders}

The education level of construction industry personnel is the key to effective training programs and the implementation of building energy codes in China.

Currently, average education level in the construction industry varies from middle school and below to undergraduate and above, depending on which sub-industry is examined. For example, building designers, drawing inspectors, construction inspectors, and quality supervisors often have bachelor degrees. Construction companies' employees include both managers and construction workers. Managers often have at least a college education, while construction workers often have education degrees at the middle school level or below. Testing engineers have college degrees (Table 4-2).

Besides education received during their school years, employees of construction industries are encouraged to take title exams for relevant certificates. Since 1994, China has formed a comprehensive title examination system for construction industry employees. Through the examination and assessment, construction industry employees get the corresponding titles or licensing (Table 4-2). A certificate remains valid for about two to three years and when it is close to expiring, the holder needs to 
go through registration procedures at the designated agency and fulfill requirements of continuing education.

Table 4-2 Average Education Level and Title Exams for Certificates by Stakeholders

\begin{tabular}{|c|c|c|c|}
\hline $\begin{array}{c}\text { Key } \\
\text { stakeholders }\end{array}$ & $\begin{array}{c}\text { Affiliated } \\
\text { organizations }\end{array}$ & $\begin{array}{c}\text { Average } \\
\text { education level }\end{array}$ & $\begin{array}{c}\text { Relevant title exams } \\
\text { for certificates }\end{array}$ \\
\hline $\begin{array}{l}\text { Building } \\
\text { designers }\end{array}$ & $\begin{array}{l}\text { Building design } \\
\text { companies, } \\
\text { building research } \\
\text { entities }\end{array}$ & Undergraduate and above & \multirow{2}{*}{$\begin{array}{l}\text { Registered architect, certified } \\
\text { structural engineer, certified } \\
\text { electrical engineer, certified } \\
\text { equipment engineer, quality } \\
\text { inspector, geotechnical } \\
\text { engineer, interior designers, } \\
\text { certified cost engineer, cost } \\
\text { engineer, etc. }\end{array}$} \\
\hline $\begin{array}{l}\text { Drawing } \\
\text { inspectors }\end{array}$ & $\begin{array}{l}\text { Drawing } \\
\text { inspection } \\
\text { companies }\end{array}$ & $\begin{array}{l}\text { Undergraduate and above } \\
\text { (with many years of } \\
\text { working experiences) }\end{array}$ & \\
\hline $\begin{array}{l}\text { Construction } \\
\text { managers }\end{array}$ & \multirow{2}{*}{$\begin{array}{l}\text { Construction } \\
\text { companies }\end{array}$} & College & \multirow{3}{*}{$\begin{array}{l}\text { Constructor, certified cost } \\
\text { engineer, cost engineer, } \\
\text { construction workers, } \\
\text { technician, security engineer, } \\
\text { quality inspector, etc. }\end{array}$} \\
\hline $\begin{array}{l}\text { Construction } \\
\text { workers }\end{array}$ & & Middle school and below & \\
\hline $\begin{array}{l}\text { Construction } \\
\text { inspectors }\end{array}$ & $\begin{array}{l}\text { Construction } \\
\text { inspection } \\
\text { companies }\end{array}$ & Undergraduate & \\
\hline $\begin{array}{l}\text { Testing } \\
\text { engineers }\end{array}$ & $\begin{array}{l}\text { Testing companies } \\
\text { or labs }\end{array}$ & College & Certified testing engineer \\
\hline $\begin{array}{l}\text { Quality } \\
\text { supervisors }\end{array}$ & $\begin{array}{l}\text { Quality } \\
\text { supervision } \\
\text { stations }\end{array}$ & Undergraduate & Supervision engineer \\
\hline
\end{tabular}

\subsubsection{Current Training Activities in China}

Training is an important component in China's current efforts to promote the compliance and implementation of building energy codes. The most common training form is training seminars. The target trainees for design standards of energy efficiency for residential and public buildings include engineers from building design companies and drawing inspection companies. The target trainees for Code for Acceptance of Energy Efficient Building Construction include construction managers, engineers from construction inspection companies, testing companies and labs, and quality supervision stations.

CABR, the national developer of most building energy codes in China, often begins a national training seminar when a new or updated national building energy code is officially issued.

Local (provincial or city) construction administrative commissions provide or organize training seminars at local or sectoral level. Some of these training seminars 
are free to trainees while others involve a fee. Invited trainers are well-known experts and scholars in the field.

Construction companies often organize free training activities (such as a training class or on-site training) for their workers. Trainers are experts or peers with an advanced knowledge about the training subject(s).

Currently, there are no online training activities on building energy codes taking place in China.

\subsection{Implementation in Urban, Suburban and Rural Areas}

The compliance rate of building energy codes in urban areas, especially in largeand mid-sized cities that have undergone annual national inspection for building energy efficiency, is satisfactory, with more than $90 \%$ in both the design and construction stages.

The implementation status of small cities and towns in Changchun and Ningbo is similar to these urban areas, according to local stakeholders. The main reasons are that the neighboring small cities and towns are close to the urban areas, and share the same or similar third-party companies for the implementation of building energy codes.

The current residential building energy codes, which target apartment buildings, do not apply to single homes and low-rise buildings, which are more commonly seen in rural areas. The development and implementation priority in China is more on urban areas than rural areas. There are few monitoring and inspection infrastructures established in rural areas.

The Regulation of Energy Conservation and Management in Civil Buildings (2006) explicitly states that this regulation does not apply to self-built, low-rise residential buildings in rural areas. However, any new buildings ${ }^{12}$ supported by governmental or international funding in the remote and rural areas should follow the same compliance and enforcement procedures as in the urban areas.

\footnotetext{
${ }^{12}$ These buildings are applied to the residential and public buildings defined by design standards
} 
5.Project Development 


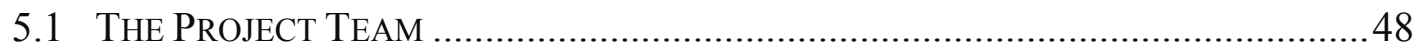

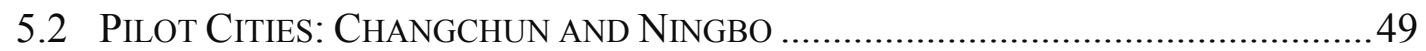

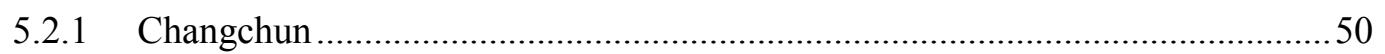

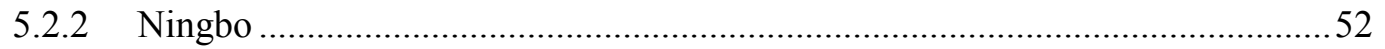

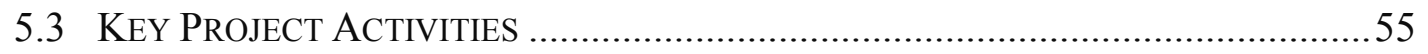

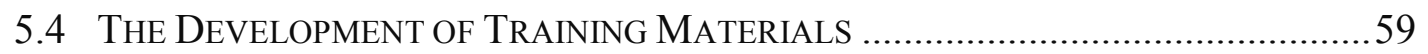

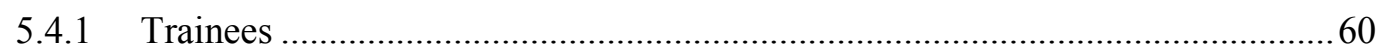

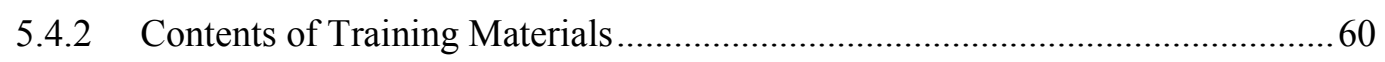

5.5 The Development of the Training Website And On-Line Training ........63

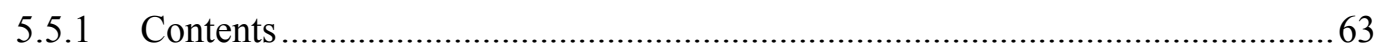

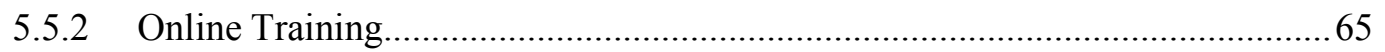

5.6 PROJECT EXPERIENCES AND LESSONS LEARNED ..............................................66

5.6.1 The Selection of the Right Chinese Collaborator(s) .............................................66

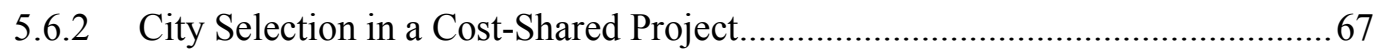

5.6.3 Evolving Understanding of the Implementation Issues and Original Plans .......68

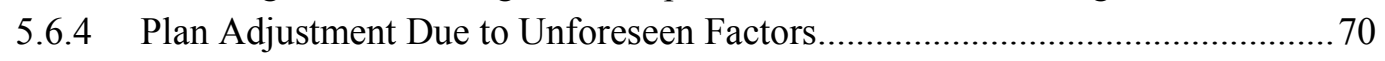

5.6.5 The Development of Training Materials ................................................................. 71

5.6.6 The Development of a Training Website and Online Training ........................... 72 
This chapter introduces the project development activities of the DOS project, including the project team (Section 5.1), pilot cities (Section 5.2), and key project activities (Section 5.3). Since a major project objective is to help improve the implementation of building energy codes through training activities, the chapter provides details on the development of training activities, including the development of training materials (Section 5.4), and online training activities through the training website (Section 5.5).

Project experiences and lessons are discussed as well (Section 5.6), including the selection of collaborator(s) (Section 5.6.1), city selection in a cost-shared project (Section 5.6.2), the conflict between evolving understanding of the implementation issues and original plans (Section 5.6.3), the development of training materials (5.6.4), the development of a training website and on-line training (5.6.5), as well as plan adjustment due to unforeseen factors (Section 5.6.6).

\subsection{The Project Team}

The project team is comprised of the Pacific Northwest National Laboratory (PNNL) - a U.S. national laboratory which provides technical and policy support to the development of building energy codes for the U.S. Department of Energy (DOE), the China Academy of Building Research (CABR) - China's national developer of building energy codes, and the Beijing Energy Efficiency Center (BECon) - an active energy research organization with comprehensive working experiences related to China's national energy policies and project development.

PNNL (www.pnnl.gov) is the lead organization of the project team. PNNL has been conducting research, technology development and deployment programs in support of energy efficiency in the building sector for over three decades. PNNL is the leading technical organization supporting DOE on building energy code issues and has extensive experience in local enforcement issues. Since 2007, PNNL has been heavily involved in the core work of the APP Buildings and Appliances Task Force Project 6 Enhancement of Building Energy Codes, including country studies and a comparison study of APP building energy codes. The role of PNNL is to lead the project development, working closely with Chinese collaborators.

CABR (www.cabr.com.cn) is the largest and most diverse research body in China's construction sector. CABR is the chief developer of nearly all of China's national building energy codes and other building standards and codes. On behalf of MOHURD, CABR is responsible for interpreting and maintaining China's building energy codes, and providing national training on the newly-released building energy codes. The role of CABR is to provide technical support to the project team. 
BECon (www.beconchina.org), one of the most influential energy efficiency organizations in China, works closely with NDRC, China's political powerhouse in charge of national economic and social development and planning. BECon has been deeply involved in many large-scale international and domestic energy efficiency projects, such as the China End-use Energy Efficiency Program (NDRC/GEF ${ }^{13}$ / $\mathrm{UNDP}^{14}$ ) and Development of an Energy Strategy for Energy Conservation Priority (NDRC). The role of BECon is to provide policy support to the project team.

\subsection{Pilot Cities: Changchun and Ningbo}

Changchun City and Ningbo City (Figure 5-1) were recommended by CABR to be selected as pilot cities to represent two climate zones: the severe cold and cold zone and the HSCW zone respectively. These two zones also houses China's two most population-intensive and economic-active regions.

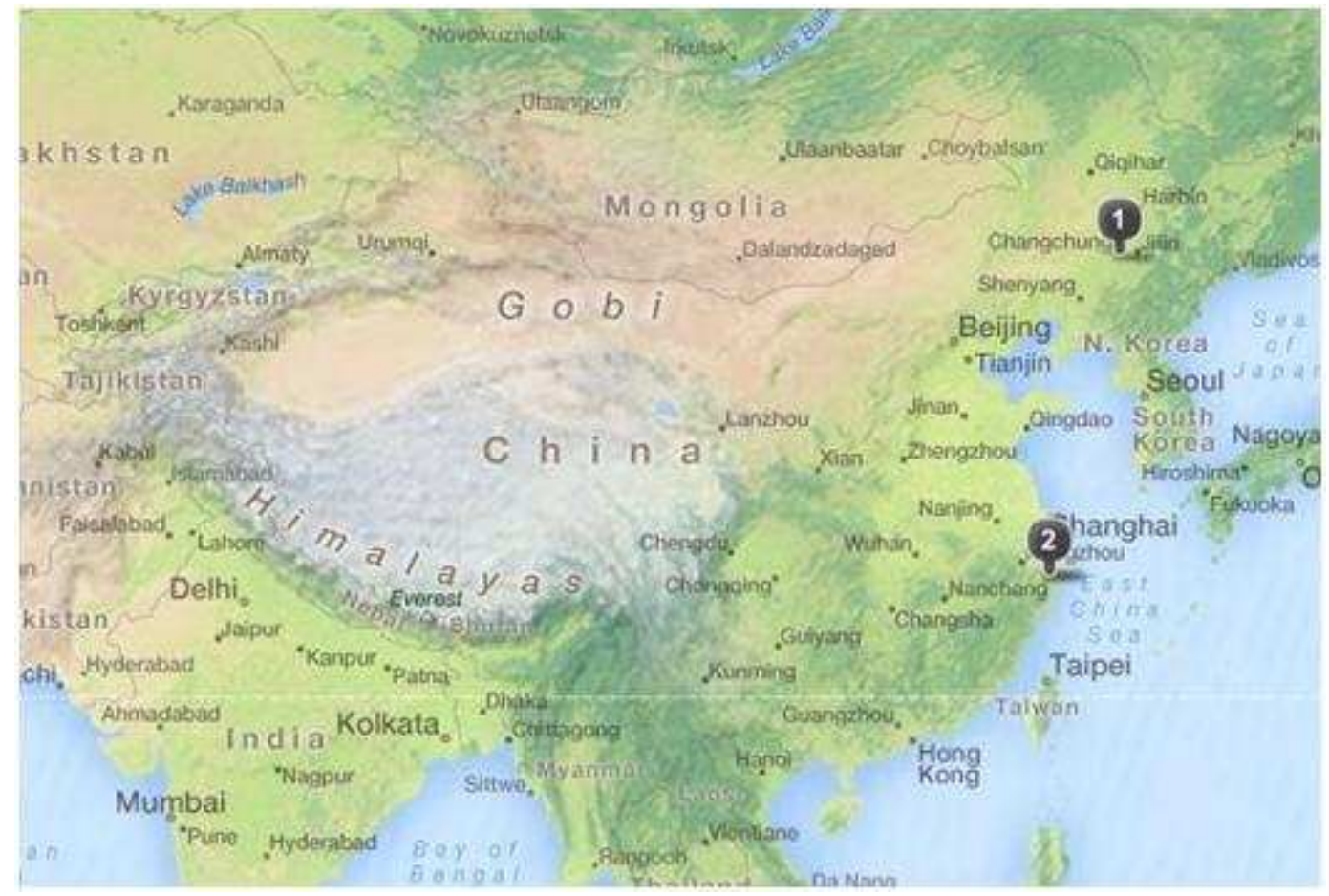

Figure 5-1 The Location of Changchun (1) and Ningbo (2)

\footnotetext{
${ }^{13}$ GEF refers to Global Environmental Facility.

${ }^{14}$ UNDP refers to United Nations Development Programme.
} 


\subsubsection{Changchun}

Changchun, meaning "Long Spring" in Chinese, is the capital and largest city in Jilin province. Located in the northeastern part of China, Changchun has a monsooninfluenced, humid and continental climate, with a long, cold and dry winter. It is categorized as a severe-cold-and-cold climate zone according to Chinese building energy codes. Changchun had an urban population of 3.6 million with a GDP of US\$28.6 billion in 2007. As the largest automobile manufacturing location in China, Changchun is often described as "China's Detroit."

Changchun started to promote building energy efficiency in 1996, when MOC (or the formal MOHURD) issued a nation-wide notice to enforce the implementation of Design Standard for Energy Efficiency of Residential Buildings in Severe Cold and Cold Zones (JGJ 26-1995). By now, Changchun has taken the following measures to promote building energy efficiency:

\section{1) Development of local technical standards and management policies}

Based on local technical level and management status, Changchun has developed a series of local technical standards and policies to promote building energy efficiency, including:

- Regulations on Application Management of Doors and Windows for Residential Buildings in Changchun City, which encouraged energy-efficient plastic-steel doors and windows, and banned the use of energy-inefficient alloy or steel doors and windows.

- Interim Methods for Design Management of Indoor Heating System in Changchun City, which required that control valves be located outside, the position of heat gauge be reserved, and heating consumption to be measured and accounted for at the household level.

- Regulations on Design of Energy-efficient Walls for Residential Buildings in Changchun Regions ${ }^{15}$, which provided requirements for construction processes and technical criteria of a variety of energy-efficient walls.

- Regulations on Design of Roofing Insulation for Residential Building in Changchun City, which provided requirements for the thickness of insulation layers by insulation materials.

- Notice on Accelerating Development and Management of New Building Materials and Notice on Implementation of Energy-efficient Technologies (Products) and Energy-efficient Building Certification System, which has

\footnotetext{
${ }^{15}$ Changchun Regions includes Changchun city, its surrounding small cities, towns and rural areas.
} 
promoted the use of energy-efficient building materials and discouraged the use of solid clay bricks since 2005.

- The Eleventh Five-year Development Plan for the Innovation of Wall Materials and the Promotion of Building Energy Efficiency.

\section{2) Enforcement of building energy codes}

In order to enhance the compliance of design standards at design stage, Changchun requires that Inspection Report on Building Energy Conservation, prepared by the drawing inspection companies, ensures the compliance of building drawing to design standards for building energy efficiency. The report must be signed by the responsible inspector(s) and drawing inspection company, which prepares the report. The inspection report should be attached with relevant calculation documents. If one fails to meet the above requirements, the construction and acceptance permit would not be issued.

The Changchun government has taken great efforts to promote the Code for Acceptance since it was released in 2007. For example, Changchun carried out a survey specifically for construction quality of energy efficiency component in a construction project.

By 2010, the compliance rate at both the design and construction stage in Changchun was $100 \%$.

\section{3) Training and research}

The Changchun government has undertaken a series of training and outreach activities to promote building energy efficiency, such as providing training and information dissemination of Regulations on Energy Conservation in Civil Building (400 participants from building design, construction, inspection, manufactures, and local construction officials), JGJ 26-1995, GB 50189-2005, and GB50411-2007.

They also organized and supported related scientific and research entities to provide technical support through research projects, i.e. Study of Current Development Status of Building Energy Efficiency in Changchun City, Technical Measures for Realizing Building Energy Efficiency 65\% and Technical Performance and Parameters for Energy-efficient Doors and Windows. 


\section{4) E-governance}

Changchun's government maintains a comprehensive and well-organized official website at www.changchun.gov.cn (a simpler English version is at http://en.changchun.gov.cn/e/index.aspx), introducing local governmental activities and updated city news.

Changchun construction commission maintains its information website at http://www.ccjs.com.cn/ccjs.com/cn/index.jsp, which serves as an information hub to all construction-related information. A visitor can check the updated news of the local construction industry, local regulations and policies, application process for construction permits, licenses for construction inspection companies, and licenses for construction companies. The website also provides online bidding information, including construction project announcements, bidding results, bidding agents, issued construction permits, license status of construction companies, etc.

\subsubsection{Ningbo}

Ningbo, meaning "Calm Wave", is a famous port city with a rich culture and history. It is located in eastern part China, about 280 kilometers (or 174 miles) from Shanghai. As the second largest city in Zhejiang province, the urban areas of Ningbo house 2.2 million people, with a GDP of US\$61.7 billion in 2009, nearly 63.6 percent from exports. Ningbo has monsoon-influenced humid subtropical climate, with four distinct seasons. Ningbo is categorized as the hot-summer-and-cold-winter climate zone in Chinese building energy codes.

The city has rolled out a series of efforts to promote building energy efficiency:

\section{1) Develop an institutional framework and implement national policies and regulations related to building energy conservation}

The Ningbo city government established a special working group to coordinate and lead the effort of promoting building energy efficiency. The city government implemented strict national and provincial policies and regulations of building energy efficiency, with developed specific work plans. The city also organized training on the Regulation on Energy Conservation in Civil Building. The local government requires that energy efficiency information of a building shall be presented to buyers when a building is on the market. 


\section{2) Develop plans and regulatory efforts, and strictly implement technical standards}

Ningbo developed the Outline of the Development and Planning for Building Energy Conservation in Ningbo City (2008-2025). In this outline, the Ningbo government specified goals, strategies, and implementation details of promoting building energy efficiency. Ningbo also developed the Strategic Scheme for Building Energy Conservation Technologies in Ningbo City and the Specific Plan for Building Energy Conservation in Ningbo City (2009-2011). These measures have laid out requirements for improving technical standards of building energy conservation systems while helping to promote building energy efficiency in Ningbo.

Ningbo has released over twenty implementation specifications on implementing building energy conservation techniques, measures, and management methods. Officials have also developed procedures to regulate changes in the approved designs, to avoid lowering energy conservation standards during the construction stage. In addition, the city issued the Management Measures of the Special Fund for Energy Conservation in Ningbo City.

\section{3) Establish a whole-process inspection and supervision system}

Ningbo has established the inspection and supervision system to enhance the implementation of building energy codes throughout the entire construction project process. There are four key steps in the whole-process supervision system: (1) project application, (2) building design, (3) construction, and (4) completion. Ningbo also conducted specific and random checks, which help ensure the implementation of building energy codes.

\section{4) Establish a computer management and information system to supervise building energy conservation design}

Ningbo developed its own building design software for energy efficiency. The software will not only help building energy efficiency design, but also provide a scientific, reliable, and economical evaluation system for building energy conservation. Based on this design software, Ningbo also developed management information systems for design inspection and government supervision system.

\section{5) Invest in $R \& D$ and develop supplemental design guideline}

To solve technical difficulties arising from the implementation of building energy codes, Ningbo has supported a series of R\&D projects: Study on Quantitative Standard of Building Energy Conservation in Ningbo City, Study on Construction and Application of Geothermal Heat Pump and Air-conditioning System in Ningbo City, 
Study on Design Techniques of Solar Water Heating System in Buildings in Ningbo City, and Implementation Outline and Technical Guidelines for Green Buildings in Ningbo Region, etc.

Ningbo has also released several supplemental building design guidelines, such as the Structural Details for Steam-aerated Concrete Blocks in Ningbo City and the Structural Details for Concrete and Perforated Brick Masonry Building in Ningbo City. These design guidelines considered local climate features and complemented existing building codes and standards.

\section{6) Target demonstration projects and promote renewable energy use in buildings}

Ningbo has built or is building 55 demonstration projects at the province and city levels. The floor coverage using solar and geothermal energy is about 8.7 million square meters (93.6 million square feet). Ningbo built China's first roof-mounted solar electric system.

\section{7) Conduct trainings and public information campaign}

Ningbo has organized training for construction professionals on relevant regulations and standards, particularly focused on the Energy Conservation Law and the Regulation on Energy Conservation in Civil Building. The city organized training for design inspectors on regulations, standards, and codes related to building energy efficiency. Ningbo's construction committee also organized a "night school" for construction workers to improve their technical knowledge.

\section{8) E-governance}

Like Changchun, Ningbo has operated a very comprehensive official website (http://gtog.ningbo.gov.cn/).

The Ningbo construction committee has a website (http://www.nbjs.gov.cn/GB/index.aspx) with updated news and a collection of issued national and local regulations, rules, and policies related to all construction-related information. The Ningbo construction website also houses an online application, announcing a list of new applications and approval results with the information about the process start time and application status. The website has an interactive session where anyone can post a question to department officials.

English version websites are available for both its city government (http://english.ningbo.gov.cn/) and construction commission (http://en.nbjs.gov.cn/). 


\subsection{Key Project Activities}

The DOS project was officially awarded September 18, 2008. PNNL issued a press release on the State project on December 3, 2008 (http://www.pnl.gov/news/release.asp?id=337).

The major project activity took off in December 2008, including

- Task 1 Select two pilot cities

- Task 2 Interview the key stakeholders

- Task 3 Design detailed plans

- Task 4 Provide on-site training

- Task 5 Design new plans

- Task 6 Design training materials

- Task 7 Collect feedback through focus group meetings

- Task 8 Develop online training website

- Task 9 Conduct online training and disseminate the results

The details about project activities are referred to in Appendix 6.

\section{Task 1 Select Two Pilot Cities (December 2008 - March 2009)}

The project team started the city selection in December 2008. By early March 2009, Changchun and Ningbo were identified as the two pilot cities.

The selection of pilot cities was the first challenge faced by the project team. Please refer to Section 5.6.2 City Selection in a Cost-shared Project for more information.

\section{Task 2 Interview with the Key Stakeholders (February to March 2009)}

In February and March 2009, PNNL and CABR attended two successful stakeholder meetings in Ningbo and Changchun, organized by CABR and local construction administrations. Each meeting lasted about three hours and included more than 20 participants (including policy decision makers in local construction commissions, building code developers, building designers, drawing inspection companies, construction companies, construction inspection companies, and real estate companies). The participants discussed relevant provisions in building energy codes, the problems rising from their practices, and the implementation of building energy codes.

The meeting improved PNNL's understanding of the current design and implementation issues faced by key stakeholders. 


\section{Task 3 Design Detailed Plans (April to June, 2009)}

Based on the collected input from the interview meetings with stakeholders, the project team started to design detailed work plans and develop training materials.

When designing the work plan, the PNNL team realized that the implementation issues of China's building energy codes had not been well documented and studied. For example, there was no detailed information available regarding the institution and mechanism of China's implementation system of building energy codes.

The PNNL team developed a list of implementation-related questions. The question list was later employed for follow-up discussions with CABR.

Meanwhile, the project team prepared the training plan and training materials for the scheduled training activities.

\section{Task 4 Provide On-site Training (July to September, 2009)}

In September 2009, PNNL and CABR co-organized an international seminar on the implementation of building energy codes of APP countries in Beijing. The project team members and representatives of pilot cities, as well as other domestic and international experts on building energy codes attended the seminar (Figure 5-2).

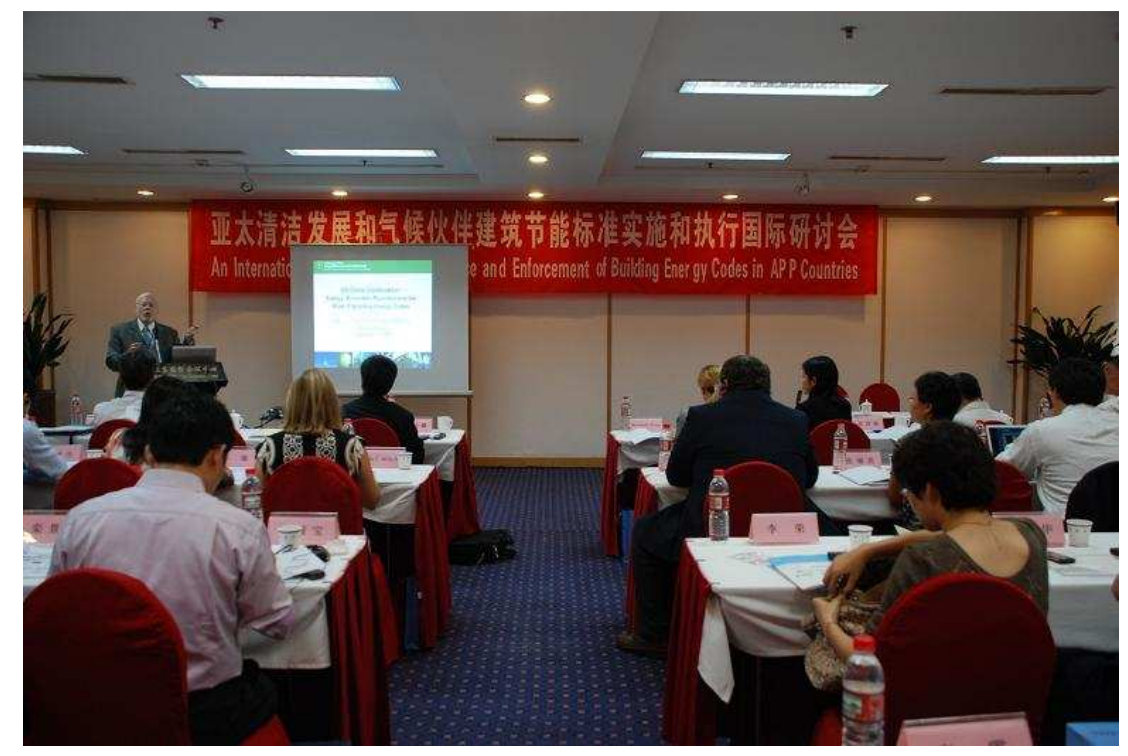

Figure 5-2 International Seminar on the Implementation of Building Energy Codes in APP Countries, Beijing, September 2009

After the international seminar, the project team provided training to key stakeholders in pilot cities (Figures 5-3 and 5-4). About 140 local participants took the training. Each training workshop had two sessions: 
- The morning session, presented by Chinese collaborators and local official(s), included (1) an introduction to local implementation of building energy codes; (2) an overview of China's energy efficiency policies and challenges; and (3) training on China's building energy codes on residential and public building.

- The afternoon session introduced the development and implementation of building energy codes in the U.S. After the introduction of each subject in the afternoon, there was an interactive discussion with attendees on the difference between the U.S. and Chinese implementation systems.

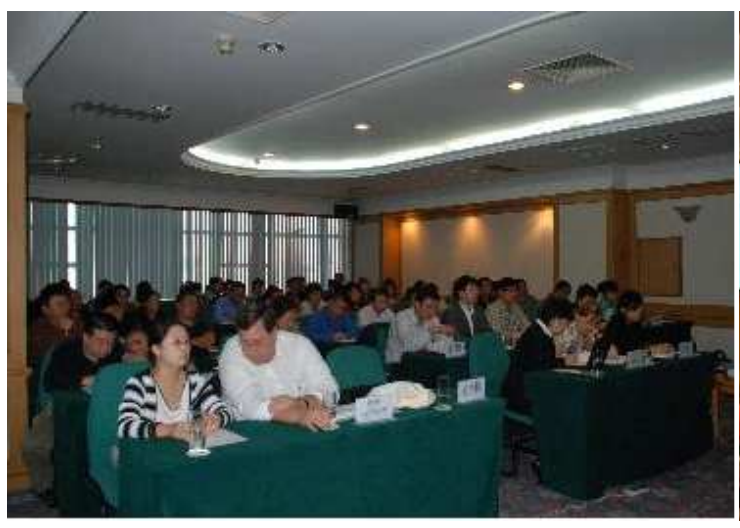

Figure 5-3 Training Seminar, Changchun, September 2009

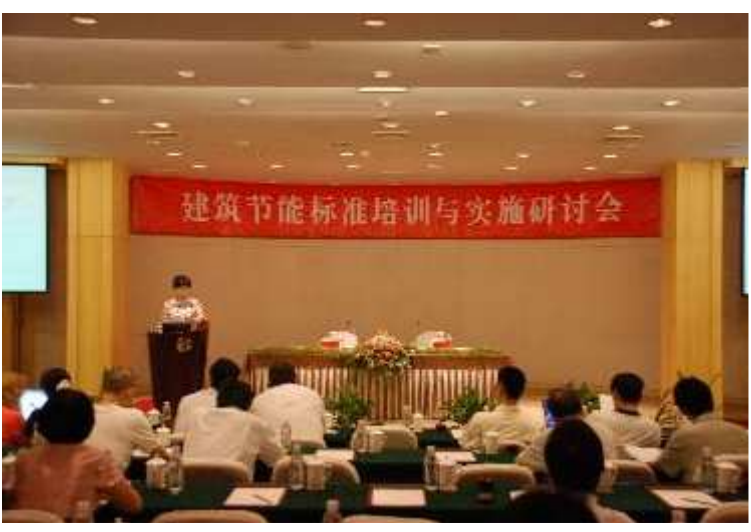

Figure 5-4 Training Seminar, Ningbo, September 2009

There were three highlights from the training:

- China's three most-respected building energy codes experts, who were the team leaders of four national building energy codes, gave the training in two pilot cities, which is a rare opportunity and big draw for local participants.

- A national energy policy expert (from BECon) gave a presentation about China's energy policy on a training seminar of building energy codes, which may help local participants gain basic understanding about national energy status and related building energy policies.

- The interactive session was helpful for Chinese building energy codes experts, local participants, and the PNNL team to exchange information and improve their understanding of the implementation issues in each country.

Through the visit, the PNNL team realized that China's current compliance and enforcement system in large- and middle-sized urban areas has improved significantly in the past two years and that the system is now a good model. 
Task 5 Design New Plans (October to December, 2009; August to October, 2010)

The trip helped the PNNL team improve its understanding of the implementation issues of China's building energy codes. A new draft plan was developed after this trip, and was later adjusted due to inputs obtained from focus group meetings and CABR's interests to experiment online training rather than the scheduled on-site training. The final executed work plan was focused on the following activities:

- Promote building energy codes through on-line information dissemination.

- Integrate the existing CABR training materials with PNNL's expertise in designing training materials and promoting training and public information to audiences with less technical backgrounds.

- Experiment with online training activities and obtain relevant experiences for future improvements.

Please refer to Section 5.6.3, The Conflict between Evolving Understanding of the Issues and Old Plans for more information.

Task 6 Design Training Materials (June 2009 to December, 2010)

The development of training materials had three stages:

1) The development of training slides for the first on-site training in Ningbo and Changchun (June to September, 2009);

2) The development of training materials according to the new work plan (January to July, 2010);

3) The development of training materials based on the feedback from focus group meetings and the adjusted new work plans (September to December, 2010);

Pease refer to Section 5.4 Development of Training Materials for more information.

Task 7 Collect Feedback through Focus Group Meetings (July to September, 2010)

Ideally, we need sufficient background information on our target audience before developing training materials for them. For example, the development of a tailored training material for construction inspectors would benefit from information such as their education background, main concerns and motivations.

In order to collect the above information, and information of the implementation issues in small towns and rural areas, local stakeholders' feedback about the training 
materials and their perceptions on on-line training, a focus group meeting was conducted in each pilot city, with a total of 25 local participants who were from building design companies, drawing inspection companies, construction companies, construction inspection companies, and quality supervision stations in Ningbo and Changchun.

A PNNL report titled, "Feedbacks from Focus Group Meeting on Training and Implementation of Building Energy Codes in China," was produced to document the information learned.

\section{Task 8 Develop Online Training Website (October 2010 to January 2011)}

The project team developed a training website at http://zmjnpx.chinabec.cn/, which is China's first training website for building energy codes, provides free on-line training. Please refer to Section 5.5, Development of the Training Website, for more information.

\section{Task 9 Conduct Online Training and Information Dissemination (January to}

\section{March 2011)}

In August 2010, CABR expressed interest in experimenting with online training, rather than the planned on-site training seminar. The on-line training aimed to reach more participants,

All the training materials were uploaded to the developed training website http://zmjnpx.chinabec.cn/. The training notice was sent out in mid-late January 2011. However, the online training coincided with the Spring Festival in early and midFebruary 2011, which affected the number of web visits to some degree. The project was hence extended one more month to collect more information regarding the on-line training activities.

Please refer to Section 5.6, On-line Training, for more information.

\subsection{The Development of Training Materials}

The development of training materials includes several issues:

- Who are the trainees? (Section 5.4.1) and

- What are the contents of the training materials? And how can the information be communicated better? (Section 5.4.2) 


\subsubsection{Trainees}

The training in this project targets (1) building designers, such as architects and engineers from building design companies, (2) drawing inspectors from drawing inspection companies, (3) construction inspectors from construction inspection companies, and (4) quality supervisors from quality supervision stations. Certainly, any other stakeholders such as code officials from local construction commissions, engineers and technicians from test laboratories and stations, construction workers and managers, and researchers, and policy makers may also benefit from reading training materials.

The PNNL team discussed with local participants during two focus group meetings and with our CABR code experts whether there is a need to have different training materials by target audience. The consistent recommendation from national and local code experts is that 1) building designers and drawing inspectors can share the same training materials, 2) construction inspectors and quality supervisors can share the same training materials.

Therefore, the main trainees of the developed training materials are:

- Building designers and drawing inspectors (target), and

- Construction inspectors and inspectors from quality supervision stations (target).

\subsubsection{Contents of Training Materials}

The core contents of the training materials contain the training presentation slides of building energy codes targeted in this project (Table 6), technical notes, calculation software, policy background, and other informational notes.

The short versions of the training presentation slides are based on the training materials presented at the first on-site training seminars in Changchun and Ningbo in September 2009. Each presentation lasted about an hour.

The long versions of JGJ26-2010 and JGJ134-2010 are based on the training materials of the two updated building energy codes presented in the first national training seminar held in Beijing in August 2010. The long version of GB50189-2005 is based on the training materials presented in an earlier national training seminar.

The training presentation of the Code for Acceptance (GB504110-2007) covers the key questions raised in the practice. 
Table 5-1 Contents of Training Presentation Slides of China's Building Energy Codes

\begin{tabular}{|c|c|c|c|}
\hline \multirow{2}{*}{$\begin{array}{c}\text { Key } \\
\text { Stakeholders }\end{array}$} & \multirow{2}{*}{ Contents } & \multicolumn{2}{|c|}{ Main Contents } \\
\hline & & Short Version & Long \\
\hline \multirow{3}{*}{$\begin{array}{l}\text { Building } \\
\text { Designers, and } \\
\text { drawing } \\
\text { inspectors }\end{array}$} & $\begin{array}{l}\text { Design Standard for Energy } \\
\text { Efficiency of Residential } \\
\text { Buildings in Severe Cold and } \\
\text { Cold Zones (JGJ26-1995, 2010) }\end{array}$ & $\begin{array}{l}\text { Discussion of the } \\
\text { difference } \\
\text { between JGJ26- } \\
1995 \text { and JGJ26 } \\
2010\end{array}$ & $\begin{array}{l}\text { A detailed } \\
\text { introduction to JGJ26- } \\
2010 \text { focused on key } \\
\text { provisions }\end{array}$ \\
\hline & $\begin{array}{l}\text { Design Standard for Energy } \\
\text { Efficiency in Residential } \\
\text { Buildings in the Hot Summer } \\
\text { and Cold Winter Zone (JGJ134- } \\
2001,2010 \text { ) }\end{array}$ & $\begin{array}{l}\text { Discussion of the } \\
\text { difference } \\
\text { between JGJ134- } \\
2001 \text { and } \\
\text { JGJ134-2010 }\end{array}$ & $\begin{array}{l}\text { A detailed } \\
\text { introduction to } \\
\text { JGJ134-2010 focused } \\
\text { on key provisions }\end{array}$ \\
\hline & $\begin{array}{l}\text { Design Standard for Energy } \\
\text { Efficiency in Public Buildings } \\
\text { (GB50189-2005) }\end{array}$ & $\begin{array}{l}\text { An introduction } \\
\text { of GB50189- } \\
2005\end{array}$ & $\begin{array}{l}\text { A detailed } \\
\text { introduction to } \\
\text { GB50189-2005, } \\
\text { provision by provision }\end{array}$ \\
\hline $\begin{array}{l}\text { Construction } \\
\text { inspectors and } \\
\text { supervision } \\
\text { inspectors }\end{array}$ & $\begin{array}{l}\text { Code for Acceptance of } \\
\text { Engineering Quality of Building } \\
\text { Energy Conservation Project } \\
\text { (GB50411-2007) }\end{array}$ & \multicolumn{2}{|c|}{$\begin{array}{l}\text { A detailed introduction to GB50411-2007 } \\
\text { focused on key questions raised in the } \\
\text { practice }\end{array}$} \\
\hline
\end{tabular}

In order to provide easy reading for trainees, the presentation slides have integrated some new features which have not been employed in most Chinese training materials, such as (1) adding new slides on questions \& answers (Q \& A) just after code provision for key questions and concepts which may be raised by a trainee, (2) color coding texts (such as black for formal code provisions, blue for general explanatory comments followed the formal code provisions, and green for Q \& A on specific issues which may be raised in the formal code texts) (Figure 5-5).

Besides the training presentation slides of China's building energy codes, the project team added training materials for building materials and calculation software for building energy efficiency, two topics raised from focus group meetings (Section 6.2.2).

In order to help trainees' understand a macro-level policy picture of the development and enforcement of building energy codes, which has not been sufficiently addressed in the current training seminars of building energy codes, the project team developed three short reports: China Energy Conservation Priority, China Building Energy Use, and A Brief Review of China Building Energy Efficiency Polices. 


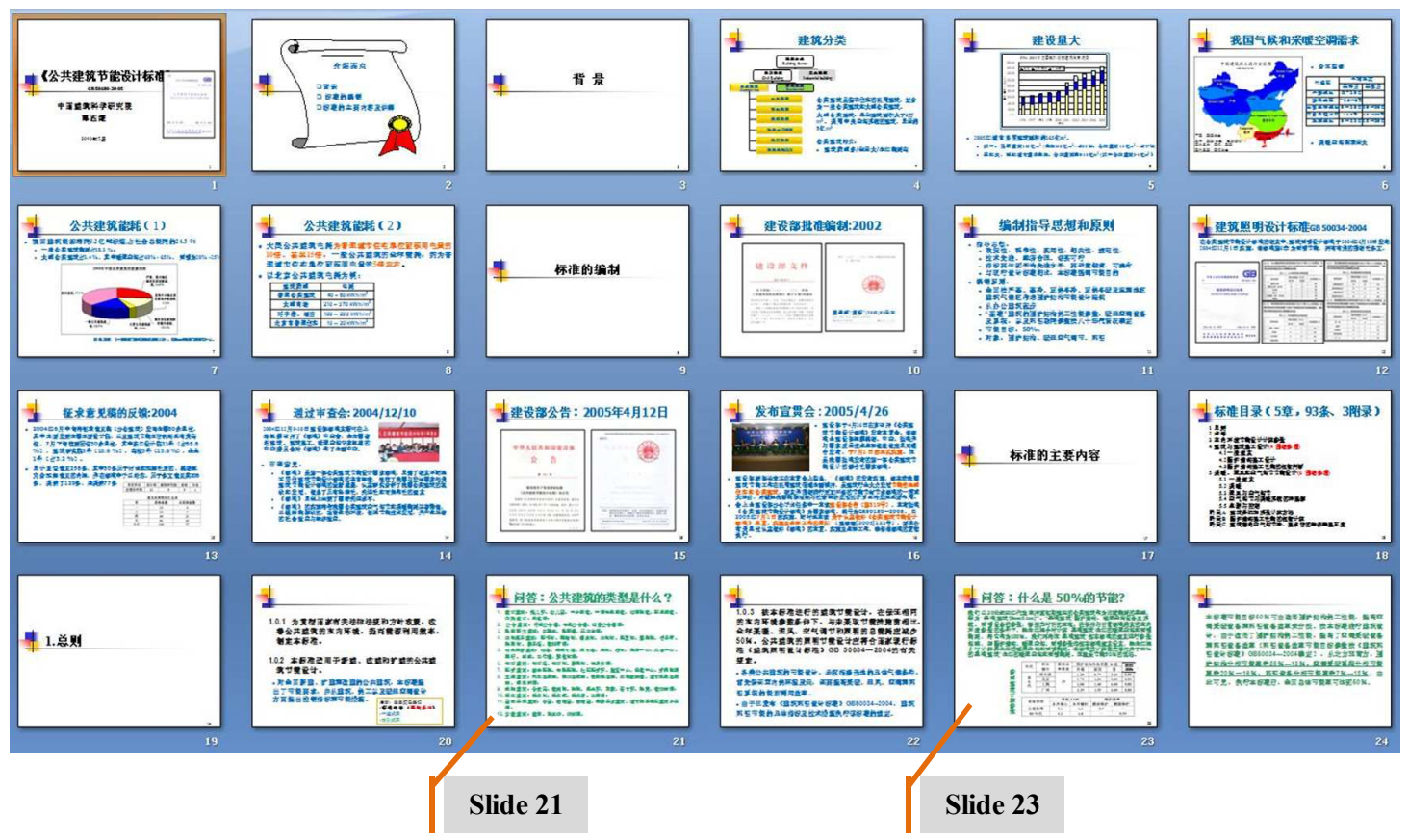

Note: The above slides are the first 24 slides of the 229 training slides for Design Standard for Energy Efficiency in Public Buildings (GB 50189-2005). The contents include a brief introduction of building energy use, the development history of GB 50189-2005, the explanation of building energy codes provisions. The green color slides (Slides 21 and 23) are Q \& A slides, including such topics as (1) what are types of public buildings? (Slide 21) and (2) what is the 50\% energy conservation target? (Slide 23)

\section{Figure 5-5 Some Training Slides of Design Standard for Energy Efficiency in Public Buildings (GB 50189-2005)}

PNNL suggested the project team produce short technical notes, a popular presentation format in the U.S, to communicate key training information. A technical note often delivers technical information in a simple language with limited pages that are "portable" to help readers grasp targeted technical information quickly. CABR picked up the technical topics, and produced four one-page technical notes, with the help of PNNL. The four short technical notes include (1) why a room gets dew? (2) A comparison of wall thermal techniques, (3) why is shape coefficient decided by number of floors? And (4) what is a reference building?

The project team also prepared a series of informational reports including (1) heat reform in the Northern China, (2) thermal bridge calculation in the updated residential building energy codes, and (3) introduction of training and information dissemination activities of building energy codes in U.S. 


\subsection{The Development of the Training Website and On-line Training}

\subsubsection{Contents}

The developed training website (http://zminpx.chinabec.cn) is titled China Building Energy Codes Training (label 1 in Figure 13). Besides a pop-up window for a survey (which does not appear in Figure 5-6), the home page contains the following contents (Table 5-2), which can be categorized into five groups:

- Core training topics with policy background (label 2) and technical contents (3);

- Other training topics containing common technical issues (5) and software (6);

- Information \& knowledge about building energy efficiency (4, 7 and 8);

- Information collection of on-line trainees' background and feedback (the popup window and 10), and

- $\operatorname{Misc}(11,12,13$ and 14).

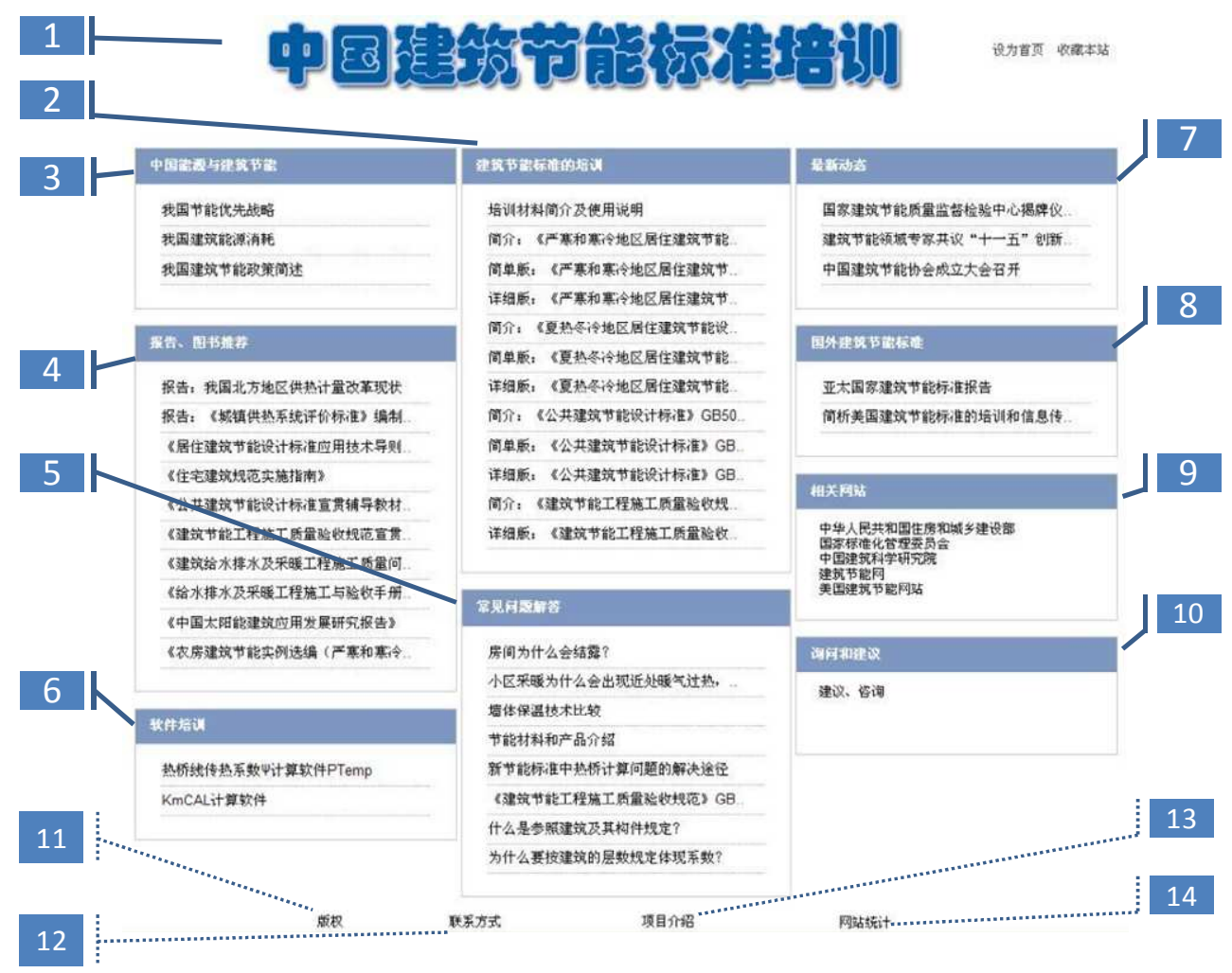

Figure 5-6 The Training Website 
Table 5-2 Contents of the Training Website

\begin{tabular}{|c|c|c|c|}
\hline \# & Topic Title & Objectives & Detailed Topics \\
\hline 2 & $\begin{array}{l}\text { China energy } \\
\text { and building } \\
\text { energy } \\
\text { efficiency }\end{array}$ & $\begin{array}{l}\text { To introduce policy } \\
\text { background of } \\
\text { building energy codes } \\
\text { in China }\end{array}$ & $\begin{array}{l}\text { - China energy conservation priority }{ }^{16}, \\
\text { - } \quad \text { China building energy use }{ }^{17} \text {, and } \\
\text { - A brief review of China building energy } \\
\text { efficiency polices }\end{array}$ \\
\hline 3 & $\begin{array}{l}\text { Training of } \\
\text { China's } \\
\text { Building } \\
\text { energy codes }\end{array}$ & $\begin{array}{l}\text { To present short and } \\
\text { long versions of } \\
\text { training presentation } \\
\text { of building energy } \\
\text { codes training } \\
\text { presentation }\end{array}$ & 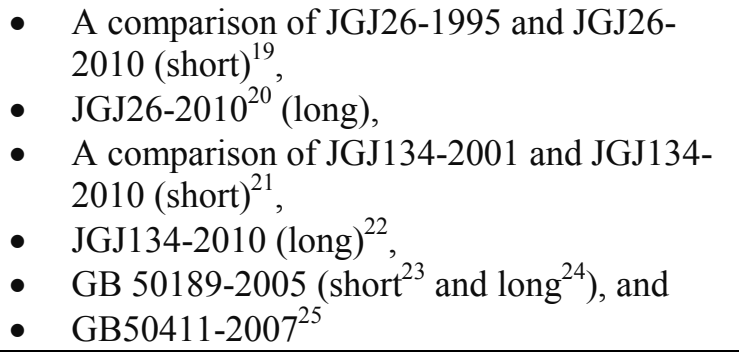 \\
\hline 4 & $\begin{array}{l}\text { Reports and } \\
\text { books for } \\
\text { China's } \\
\text { building } \\
\text { energy } \\
\text { efficiency }\end{array}$ & $\begin{array}{l}\text { To list some recent } \\
\text { reports and books } \\
\text { related to building } \\
\text { energy efficiency for } \\
\text { interested readers }\end{array}$ & $\begin{array}{l}\text { including } \\
\text { - Heat reform in the Northern China (report) } \\
\text { - Names of books related to building energy } \\
\text { efficiency }\end{array}$ \\
\hline 5 & $\begin{array}{l}\text { Common } \\
\text { questions and } \\
\text { answers }\end{array}$ & $\begin{array}{l}\text { To present of a list of } \\
\text { information notes } \\
\text { with some specific } \\
\text { and common technical } \\
\text { questions }\end{array}$ & 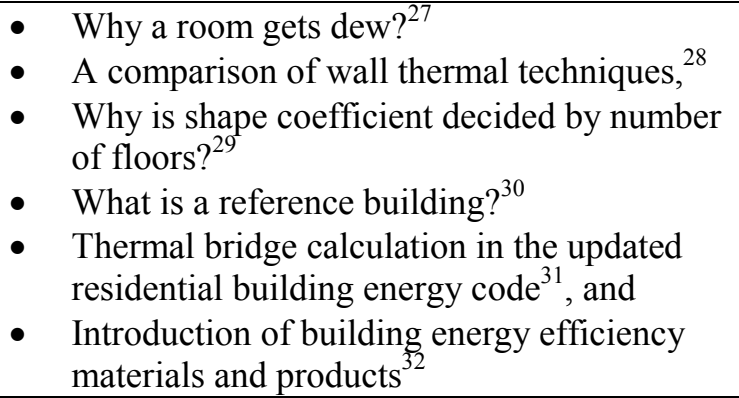 \\
\hline
\end{tabular}

\footnotetext{
${ }^{16} \mathrm{http}: / /$ zmjnpx.chinabec.cn/tabid/183/ArticleID/4658/Default.aspx

${ }_{17} \mathrm{http://zmjnpx.chinabec.cn/tabid/183/ArticleID/4657/Default.aspx}$

$18 \underline{\mathrm{http}: / / \text { zmjnpx.chinabec.cn/tabid/183/ArticleID/4656/Default.aspx }}$

19 http://zmjnpx.chinabec.cn/tabid/183/ArticleID/4671/Default.aspx

20 http://zmjnpx.chinabec.cn/tabid/183/ArticleID/4669/Default.aspx

21 http://zmjnpx.chinabec.cn/tabid/183/ArticleID/4668/Default.aspx

22 http://zmjnpx.chinabec.cn/tabid/183/ArticleID/4666/Default.aspx

23 http://zmjnpx.chinabec.cn/tabid/183/ArticleID/4666/Default.aspx

24 http://zmjnpx.chinabec.cn/tabid/183/ArticleID/4662/Default.aspx

${ }^{25} \mathrm{http} / / /$ zmjnpx.chinabec.cn/tabid/183/ArticleID/4659/Default.aspx

${ }^{26} \mathrm{http}: / /$ zmjnpx.chinabec.cn/tabid/183/ArticleID/4683/Default.aspx

${ }^{27}$ http://zmjnpx.chinabec.cn/tabid/183/ArticleID/4677/Default.aspx

${ }^{28} \mathrm{http}: / /$ zmjnpx.chinabec.cn/tabid/183/ArticleID/4675/Default.aspx

${ }^{29} \mathrm{http} / / /$ zmjnpx.chinabec.cn/tabid/183/ArticleID/4638/Default.aspx

${ }^{30} \mathrm{http} / / /$ zmjnpx.chinabec.cn/tabid/183/ArticleID/4639/Default.aspx

31 http://zmjnpx.chinabec.cn/tabid/183/ArticleID/4648/Default.aspx

32 http://zmjnpx.chinabec.cn/tabid/183/ArticleID/4674/Default.aspx
} 


\begin{tabular}{|c|c|c|c|}
\hline \# & Topic Title & Objectives & Detailed Topics \\
\hline 6 & $\begin{array}{l}\text { Software } \\
\text { training }\end{array}$ & $\begin{array}{l}\text { To introduce some } \\
\text { calculation software } \\
\text { related to building } \\
\text { energy codes }\end{array}$ & $\begin{array}{l}\text { - Calculation software for linear heat transfer } \\
\text { coefficient of thermal bridge } \mathrm{e}^{33} \text {, and } \\
\text { - KmCAL calculation software }\end{array}$ \\
\hline 7 & Updates & \multicolumn{2}{|c|}{ To present a list of news and updates related to building energy codes } \\
\hline 8 & $\begin{array}{l}\text { Introduction: } \\
\text { international } \\
\text { building } \\
\text { energy codes }\end{array}$ & $\begin{array}{l}\text { To provide reports } \\
\text { and web links about } \\
\text { international building } \\
\text { energy codes }\end{array}$ & $\begin{array}{l}\text { - Building energy codes in APP countries } \\
\text { and } \\
\text { - Introduction of training and information } \\
\text { dissemination of building energy codes in } \\
\text { the U.S. }\end{array}$ \\
\hline 9 & $\begin{array}{l}\text { Web } \\
\text { resources }\end{array}$ & $\begin{array}{l}\text { To list China and } \\
\text { international websites } \\
\text { related to building } \\
\text { energy codes }\end{array}$ & $\begin{array}{l}\text { - } \text { MOHURD }^{37}, \\
\text { - } \text { CABR }^{38}, \\
\text { - China building energy conservation } \\
\text { network } \\
\text { - } \quad \text { Building Energy Codes Program (U.S. } \\
\text { DOE) }\end{array}$ \\
\hline 10 & $\begin{array}{l}\text { Inquiries and } \\
\text { suggestions }\end{array}$ & \multicolumn{2}{|c|}{$\begin{array}{l}\text { To solicit inquiries and suggestions regarding the training website or } \\
\text { issues of building energy codes in general }{ }^{41}\end{array}$} \\
\hline 11 & Copyright & \multicolumn{2}{|c|}{ To present information related to copyright ${ }^{42}$} \\
\hline 12 & Contact & \multicolumn{2}{|c|}{ To present information related to contact ${ }^{43}$} \\
\hline 13 & $\begin{array}{l}\text { Project } \\
\text { Introduction }\end{array}$ & \multicolumn{2}{|c|}{ To present information related to project introduction ${ }^{44}$} \\
\hline 14 & $\begin{array}{l}\text { Website } \\
\text { Statistics }\end{array}$ & \multicolumn{2}{|c|}{ To present information related to website statistics ${ }^{45}$} \\
\hline
\end{tabular}

\subsubsection{Online Training}

The online training took place on January $24^{\text {th }}, 2011$. CABR and BECon sent out 258 invitations to national, provincial, and local stakeholders related to building energy efficiency (especially building energy codes).

When a visitor enters into the training website, there is a pop-up window (Figure $5-7$ ) asking the visitor to take a short survey in another window ${ }^{46}$ and answer three questions about the visitor: work responsibility (drawing, drawing inspection,

\footnotetext{
${ }^{33}$ http://zmjnpx.chinabec.cn/tabid/183/ArticleID/4673/Default.aspx

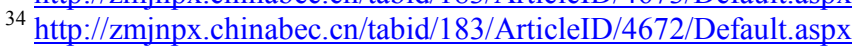

$35 \underline{\mathrm{http}: / / \text { zmjnpx.chinabec.cn/tabid/183/ArticleID/4679/Default.aspx }}$

36 http://zmjnpx.chinabec.cn/tabid/183/ArticleID/4678/Default.aspx

37 http://www.mohurd.gov.cn/

38 http://www.cabr.ac.cn/

39 http://www.chinabec.cn/

40 http://www.energycodes.gov/

${ }^{41} \mathrm{http}: / /$ www.kwiksurveys.com/online-survey.php?surveyID=IKHOMG $3 \mathrm{ebfcc0b}$

42 http://zmjnpx.chinabec.cn/Default.aspx?tabid=187

43 http://zmjnpx.chinabec.cn/Default.aspx?tabid $=185$

44 http://zmjnpx.chinabec.cn/Default.aspx?tabid=186

$45 \mathrm{http}: / /$ www.51.1a/?2553536

46 http://www.kwiksurveys.com/online-survey.php?surveyID=IKHLLL b2309a9b
} 
construction management, or construction inspection), main work location (urban, suburban or rural), and which province or city the visitor is from. The survey is expected to help the project team to learn some basic background information about the visitor.
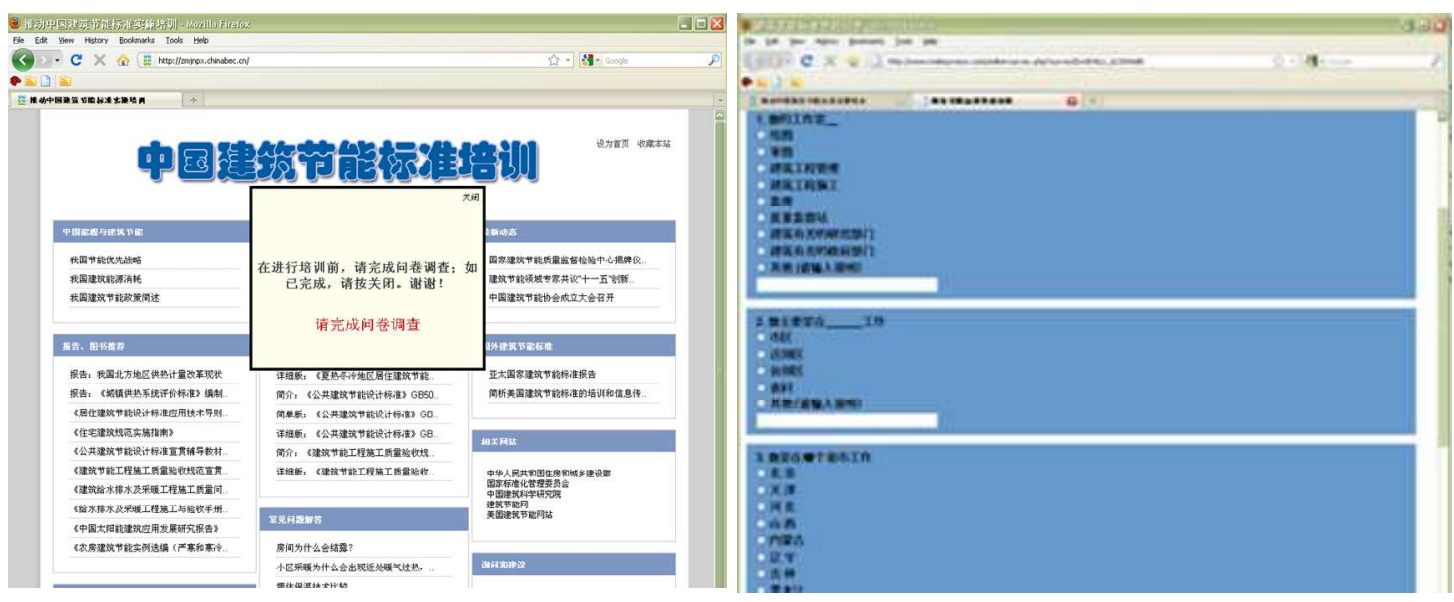

Figure 5-7 The Pop-up Window and the Survey Window

There is an inquiry link (label 10 in Figure 5-6) to another window. A visitor is asked to provide suggestions regarding to the training website and any questions s/he may have.

Through March $20^{\text {th }}$, there have been 532 visitors/frequencies to the training website.

\subsection{Project Experiences and Lessons Learned}

\subsubsection{The Selection of the Right Chinese Collaborator(s)}

Selecting the right collaborator is vital to any project.

For a collaborative China project, it is important to select the right Chinese collaborator(s). A right Chinese collaborator is the ground troop which not only provides critical inputs for the project development, but also executes project activities that take place in China. An ideal Chinese collaborator may have strong technical capabilities relevant to the project, a deep understanding of the target issues, and a comprehensive network at the local, industrial or/and national level that the project needs.

CABR is the national developer of nearly all China's building energy codes. The DOS project includes China's best building energy codes experts from CABR: Mr. 
LIN Haiyan, deputy CABR director and the team lead of Design Standard for Energy Efficiency of Residential Buildings in Severe Cold and Cold Zones (JGJ 26-1995, 2010) and Design Standard for Energy Efficiency in Residential Buildings in the Hot Summer and Cold Winter Zone (JGJ134-2001, 2010), Mr. LAHG Siwei, retired CABR's chief engineer and the team lead of Design Standard for Energy Efficiency in Public Buildings (GB 50189-2005); and Mr. SONG Bo, the team lead of Code for Acceptance of Engineering Quality of Building Energy Conservation Project (GB50411-2007).

CABR has good networks at the local and national level. CABR's three team members are all highly respected and widely known in the field of building energy codes in China. The two training seminars presented by three leading national building energy codes experts were a big draw for local participants. CABR has provided tremendous support in coordinating with local stakeholders, and providing technical inputs for the project. For example, CABR agreed to provide their full version of training presentation of four building energy codes (JGJ 26-2010, JGJ1342010, GB 50189-2005, and GB50411-2007) to the online training website for free access.

BECon is a well-known energy efficiency organization under China's national energy policy think tank, Energy Research Institute, with a close tie to NDRC.

$\mathrm{BEC}$ on has been involved in a series of high-profile domestic and international energy efficiency policy research and projects. BECon provided excellent policy research and analysis regarding China's policies on building energy efficiency.

Both CABR and BECon are great assets for this project.

\subsubsection{City Selection in a Cost-Shared Project}

During the development of our project proposal, we selected a procurement project of energy efficiency products, supported by the Blue Moon Fund (BMF), as the cost-shared project to the DOS project. We proposed that the DOS project and the BMF project would share the same two pilot cities for easy coordination and cost saving. The pair of projects was expected to serve as two complementary approaches to promoting building energy efficiency in Chinese cities: the DOS project would be focused on the implementation of building energy codes in new buildings, and the BMF project would develop a procurement mechanism to promote energy efficiency products/technologies in buildings.

After the two projects started, the first difficulty we encountered was city selection: First, the two projects were required to work with two different local 
administrative agencies: the DOS project needed support from local construction administration, while the BMF project needed strong support from a mayor's office to provide some type of financing guarantee which is not easily obtained in China. Second, there were two different groups of Chinese collaborators for each project, which made the selection and communication more complicated. Third, the selected pilot cities had to be located in both the severe cold and cold zone and the HSCW zone, a requirement of the DOS project.

The selection of pilot city actually started in September 2008 after the announcement of the DOS project approval, while the BMF project started one month earlier. By February 2009, the city officials in Changchun and Ningbo, which showed interests in the DOS project, decided not to take part in the BMF project, while the BMF project secured support from one city, Nanyan, and was still looking for another pilot city. It became clear that the two projects needed to work with a different pair of pilot cities for the best interest of each project. Some proposed cost-shared activities, such as testing bulk procurement of energy efficiency materials to support code enforcement, had to be dropped from the plan.

The lesson we learned is that it is important to understand the level of local government engagement in a China project which needs local support: who are the local governmental agencies involved, what support is expected and can actually be obtained. Ideally, a project team needs to ensure an adequate level of commitment before selecting a pilot city, as demonstrated by its willingness to commit staff and other necessary resources to the effort in the short term. However, obtaining this commitment is often easier after a project has been formally authorized.

\subsubsection{Evolving Understanding of the Implementation Issues and Original Plans}

The project development is a learning process. The project team, especially PNNL, has experienced an evolving understanding of the implementation issues of building energy codes in China.

China has experienced dramatic improvements in its implementation of building energy codes, especially in urban areas, since an annual national inspection for building energy efficiency was carried out in 2005 and the release of the Code for Acceptance (GB50411-2007) in 2007.

Before the DOS project took off in 2009, few reports, however, were available in either Chinese or English to document this change, as well as implementation mechanism and institution in China. Few reports about the implementation of building energy codes in other countries were introduced to China. 
With little knowledge of China's fast-improving implementation status for the international community of building energy codes and the implementation status of other countries for the code community in China, both communities converged to a false consensus about the poor implementation status of building energy codes in China, which actually understated China's recent achievements, especially in the urban areas.

The DOS project proposal was developed under this wide-spread consensus: the implementation status in China was weak, and there was a great need to improve China's implementation system.

Thanks to meetings with local and national code experts (stakeholder meeting, training seminars and focus group meetings), on-site construction visits, and a visit to CABR's software institute, the PNNL team realized that the wide-spread perception about China's implementation status was inaccurate. China has been establishing a rather robust implementation system especially in the urban areas, while its enforcement in rural areas and small cities is not satisfactory. Lack of knowledge of building energy issues may be one of the barriers preventing successful enforcement of building energy codes in small cities.

Based on the improved understanding obtained after the on-site training in September 2009, a new work plan was developed with focus on the following issues:

- Target key stakeholders in small towns and cities in Ningbo and Changchun, who may have less technical knowledge than their counterparts in urban areas of the same cities;

- Integrate the existing CABR training materials with PNNL's expertise in designing training materials and promoting training and public information to audiences with less technical backgrounds; and

- Promote building energy codes through online training and information dissemination.

However, the first point of this new work plan was subject to further adjustment based on inputs of focus group meetings held eight months later. Through the meetings with local stakeholders, PNNL learned that the implementation of building energy codes in small cities and towns (near the urban areas) in both Ningbo and Changchun is advanced. The compliance and enforcement for new buildings in these small cities and towns often follows the same system as in the cities. For example, building design companies, drawing inspection companies, construction companies, construction inspection companies and quality supervision stations work for new buildings in both urban areas and small cities and towns near urban areas. 
Other important feedback from the focus group meeting is that local stakeholders were very interested in online training and information dissemination activities of building energy codes. In order to reach more participants, CABR expressed strong interest in experimenting with online training, rather than the planned on-site training seminar. CABR pointed out that (1) the on-site training in these two pilot cities would access the same pool of audiences. The outputs from their third visit, even with updated training materials, may be very limited, or as much as what they would collect from online training. (2) Online training of building energy codes is a new experience in China. It may help reach a large number of audiences more directly and quickly, with more feedback information. (3) CABR would prefer to focus on the development of online training websites and related training materials, and learning more about online training experiences with the remaining resources.

So, the executed work plan was finalized as the following:

- Promote building energy codes through online training and information dissemination activities;

- Integrate the existing CABR training materials with PNNL's expertise in designing training materials and promoting training and public information to audiences with less technical backgrounds; and

- Experiment with online training activities and obtain relevant experiences for future improvements.

The understanding of China's implementation issues of building energy codes has evolved throughout the project development. The project team amended the proposed project activities accordingly, in order to reach the project goals and objectives which help China implement its building energy codes.

\subsubsection{Plan Adjustment Due to Unforeseen Factors}

The project had encountered several unforeseen factors which led to the plan adjustment.

The first unforeseen factor was the difficulty in city selection, which forced the cost-shared projects to work separately in a different pair of cities and dropped the proposed cost-shared project activities (Section 5.6.2).

Due to the H1N1 flu that happened in China from late May to July 2009, the PNNL team postponed a scheduled project trip two months later, at the request of the Chinese collaborators. 
The evolving understanding on the implementation issues of China's building energy codes shaped the work plan and project activities accordingly (Section 5.6.3).

The late release of the updated design standards for building energy efficiency in residential buildings (JGJ 26-2010 and JGJ134- 2010) delayed project progress. The two updated design standards were expected to be released by December 2009 and CABR suggested the project should provide training of the most updated design standards. However, the two updated design standards were actually issued in August 2010 by MOHURD. The delay made it difficult to execute the original plan, and to have a six-month interval between the focus group meetings and the second training activities as proposed. The project plan had to be adjusted accordingly.

Our experience in dealing with unforeseen factors is to maintain good communication with both Chinese collaborators and the client, respecting reasonable requests of Chinese collaborators and working with both to develop new plans within the project scope.

The trust established with the Chinese collaborators and client is very important for the project development and execution.

\subsubsection{The Development of Training Materials}

The training materials developed within the DOS project are mainly based on CABR and BECon's new and existing efforts (such as training presentation slides, technical notes, technical reports etc.), with guidance from PNNL.

The project team also benefited tremendously from input obtained from two focus group meetings: participants indicated that they liked the developed training materials, with suggestions that more training information needed to be about building energy efficiency products, building materials and software application related to building energy codes. The input received has been integrated into the improvements of training materials and uploaded to the training website.

Ideally, the developed training materials should undergo several cycles of revisions, with input from code experts and especially trainees.

The DOS project only scheduled one focus group meeting in each pilot city. Due to time limitations, local participants went through the developed training materials very quickly. The project team believed that there would have been more useful comments obtained from local participants had there been one or two additional focus group meetings scheduled in each city. For example, the project team would like to have another focus group meeting or a follow-up project to focus on the development 
of training materials of the Code for Acceptance tailored to the needs of key stakeholders (construction companies, construction inspection companies, testing companies, quality supervision stations, building developers and equipment and building materials supply companies) (see Section 6.2).

\subsubsection{The Development of a Training Website and Online Training}

With evolving understanding of the implementation issues of China's building energy codes, the project focus was shifted to the development of a training website and the implementation of online training activities, which are believed to provide audience with easily-accessed information and flexibility, thereby making it possible to reach more trainees (Section 5.6.3).

If time and financial resources permit, the project team would have liked to have at least one more focus group meeting in order to obtain the feedback from local participants about the training website and online training activities. The project team would also suggest hiring a professional web site management firm that can provide more sophisticated information such as the number of visitors for each developed link, staying times, and the approximate locations of each visitor. This collected web usage information may help analyze the impact and performance of online training $\operatorname{activities}^{47}$.

The strength of the online training could be realized only if a visitor takes online training and learns information which is of interest or useful to them. Users may also download material and study at their leisure time. The DOS project sent the training information to nearly 250 people (code experts, policy researchers, decision makers, etc.), and generated about a frequency of 580 visits in two months. Web visits have not been growing as fast as the project team expected.

How we get more people to read and benefit from available training would be the next important question.

\footnotetext{
${ }^{47}$ The impact of training activities may not be easily measured and evaluated, even for on-site training.
} 
6.Policy Implications 
6.1 IDENTIFIED IMPLEMENTATION DIFFICULTIES AND THE ROLE OF TRAINING ..............75

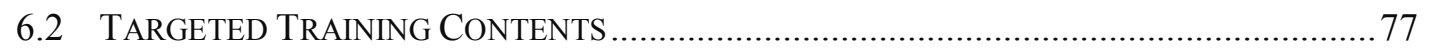

6.2.1 Targeting the Code for Acceptance for Training …………………………............... 77

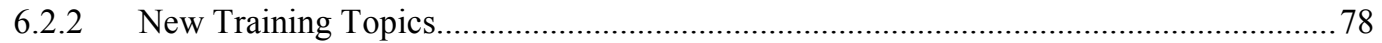

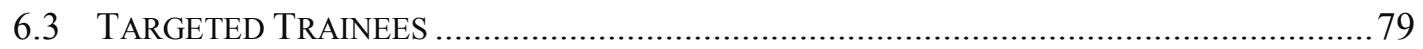

6.3.1 Building Developers, Construction Workers, and Consumers.......................................79

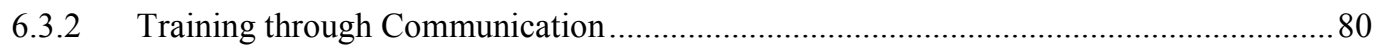

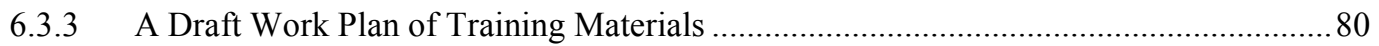

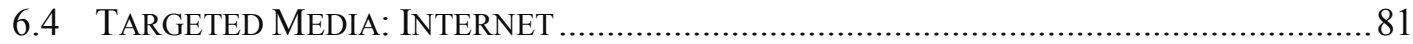

6.5 THE ROLE OF GOVERNMENT IN TRAINING AND INFORMATION DISSEMINATION ........83

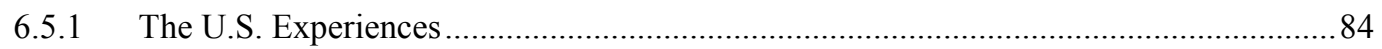

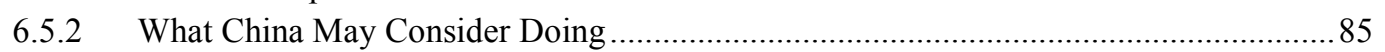

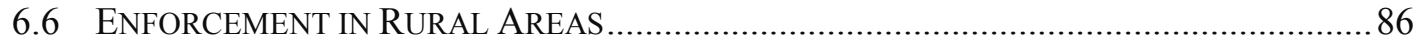




\subsection{Identified Implementation Difficulties and the Role of Training}

China's compliance rates in the inspected cities have dramatically improved since 2005, increasing from 53\% and $21 \%$ for design and construction, respectively, in 2005 to $98 \%$ and $90 \%$ in 2009 (Figure 7). Changchun and Ningbo, the two inspected cities, have greatly improved since 2005 . Their local construction commissions, however, expressed that they are still facing challenges in the implementation of building energy codes.

What are these challenges? Or, what are the common difficulties encountered in workday activities related to the implementation of building energy codes? The project team asked the same question to local stakeholders. Table 6-1 documented the feedback obtained from two focus group meetings, with brief comments from the project team.

The project team understands that the collected feedback may not be a good representation for the majority of Chinese cities, due to the limited sample size and the advancement of the implementation status in these two pilot cities. However, the collected information would at least shed light on understanding some barriers that exist in the current implementation process.

Table 6-1 Identified Implementation Difficulties by Local Stakeholders

\begin{tabular}{|c|c|c|}
\hline $\begin{array}{c}\text { Key } \\
\text { Stakeholders }\end{array}$ & Identified Difficulties & $\begin{array}{c}\text { Brief Comments from } \\
\text { the Project Team }\end{array}$ \\
\hline \multirow{2}{*}{$\begin{array}{c}\text { Building } \\
\text { design } \\
\text { companies }\end{array}$} & $\begin{array}{l}\text { Time-consuming computation for a new } \\
\text { building with an irregular building shape } \\
\text { - When the shape of a new building is } \\
\text { not a regular one defined by the design } \\
\text { code, building designers often find } \\
\text { themselves absorbed by difficult } \\
\text { energy-saving computations required } \\
\text { by the design standards. }\end{array}$ & $\begin{array}{l}\text { - Should the calculation method } \\
\text { be improved? } \\
\text { - Should the software algorithm be } \\
\text { improved? } \\
\text { - Training materials about this } \\
\text { issue should be developed and } \\
\text { disseminated. }\end{array}$ \\
\hline & $\begin{array}{l}\text { A lack of knowledge about new building } \\
\text { materials and technologies } \\
\text { - Building designers often find } \\
\text { themselves having difficulties choosing } \\
\text { which type of building material is more } \\
\text { suitable to improving the building } \\
\text { energy efficiency for a designed } \\
\text { construction project. }\end{array}$ & $\begin{array}{l}\text { - Training materials about the } \\
\text { introduction of building } \\
\text { materials and technologies } \\
\text { should be developed and } \\
\text { disseminated. }\end{array}$ \\
\hline
\end{tabular}




\begin{tabular}{|c|c|c|}
\hline $\begin{array}{c}\text { Key } \\
\text { Stakeholders }\end{array}$ & Identified Difficulties & $\begin{array}{c}\text { Quick Comments from } \\
\text { the Project Team }\end{array}$ \\
\hline $\begin{array}{l}\text { Drawing } \\
\text { inspection } \\
\text { companies }\end{array}$ & $\begin{array}{l}\text { Not identified by local participants } \\
\text { Usually, drawing reviewers can } \\
\text { determine compliance with the } \\
\text { building energy codes. There are few } \\
\text { difficulties identified by participants at } \\
\text { focus group meetings. }\end{array}$ & - Good. \\
\hline \multirow{3}{*}{$\begin{array}{l}\text { Construction } \\
\text { Companies }\end{array}$} & $\begin{array}{l}\text { A lack of knowledge in identifying the } \\
\text { quality of building materials, such as } \\
\text { materials' durability and strength. }\end{array}$ & $\begin{array}{l}\text { - Training materials about } \\
\text { identification of quality of } \\
\text { building materials should be } \\
\text { developed and disseminated. }\end{array}$ \\
\hline & $\begin{array}{l}\text { Conflicted interests between high priced } \\
\text { energy-efficient building materials and } \\
\text { cheaper, but less efficient materials. }\end{array}$ & $\begin{array}{l}\text { - Training materials about } \\
\text { building life-cycle costing } \\
\text { should be developed and } \\
\text { disseminated. }\end{array}$ \\
\hline & $\begin{array}{l}\text { A lack of knowledge of building } \\
\text { techniques. }\end{array}$ & $\begin{array}{l}\text { - Training materials about } \\
\text { building techniques should be } \\
\text { developed and disseminated. }\end{array}$ \\
\hline $\begin{array}{l}\text { Construction } \\
\text { Inspection } \\
\text { Companies }\end{array}$ & $\begin{array}{l}\text { A lack of understanding of the Code for } \\
\text { Acceptance. }\end{array}$ & $\begin{array}{l}\text { - Training materials on the Code } \\
\text { for Acceptance should be } \\
\text { developed and disseminated. }\end{array}$ \\
\hline \multirow{2}{*}{$\begin{array}{c}\text { Testing } \\
\text { Companies }\end{array}$} & $\begin{array}{l}\text { A lack of knowledge, pointed out by testing } \\
\text { engineers, in the Code for Acceptance for } \\
\text { developers, construction companies, } \\
\text { construction inspection companies, and } \\
\text { equipment and material supply companies } \\
\text { - Selected samples for inspection often } \\
\text { do not meet the requirements. }\end{array}$ & $\begin{array}{l}\text { - Training materials on the Code } \\
\text { for Acceptance should be } \\
\text { developed and disseminated to } \\
\text { all the mentioned stakeholders. }\end{array}$ \\
\hline & $\begin{array}{l}\text { A lack of testing capabilities for some } \\
\text { testing companies makes it difficult to meet } \\
\text { the testing requirements }\end{array}$ & $\begin{array}{l}\text { - There is a need to invest and } \\
\text { improve current testing facilities } \\
\text { of some testing companies. } \\
\text { - Or, the testing companies that } \\
\text { cannot meet the requirements } \\
\text { should lose their testing licenses. }\end{array}$ \\
\hline $\begin{array}{l}\text { Quality } \\
\text { Supervision } \\
\text { Stations }\end{array}$ & $\begin{array}{l}\text { Lack of thorough understanding of the } \\
\text { Code for Acceptance. }\end{array}$ & $\begin{array}{l}\text { - Training materials about the } \\
\text { Code for Acceptance should be } \\
\text { developed and disseminated to } \\
\text { quality supervisors. }\end{array}$ \\
\hline
\end{tabular}


When local stakeholders were asked by the project team about their perceptions of the implementation problems, the most complaints from them were about, "the lack of knowledge," which are directly and indirectly associated with training and information dissemination.

Some local stakeholders also mentioned the importance of educating the public about building energy efficiency.

The average education level of local construction workers, which is the lowest of the whole construction industry, could be a factor for low compliance rate and/or low quality of a construction project, as suggested by local stakeholders. They thought construction workers in developed countries may have better "quality."

The quality of building materials was mentioned during the stakeholder meetings and focus group meetings. Its inconsistency is another factor that not only affects the implementation of building energy codes, but also the quality of a construction project.

Project cost control is an important decision factor identified by building developer, building design companies, construction companies, and construction

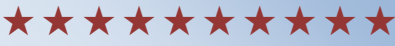

There is an ignored, under-invested and weak area in the current implementation process in China: training and information dissemination.

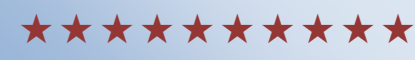
inspection companies (Section 4.1). Compromises (such as cheaper building materials that do not meet the requirements of building codes) are sometimes made in order to reduce project cost.

The above discussions seem to involve many issues of the implementation of building energy codes, and the discussion may be biased due to the fact that most of the local stakeholders we interacted with were engineers, technicians, and technical managers. However, the discussions did converge to a clear message:

There is an ignored, under-invested and weak area in the current implementation process in China: training and information dissemination.

\subsection{Targeted Training Contents}

\subsubsection{Targeting the Code for Acceptance for Training}

The training need for the Code for Acceptance is illustrated by lower compliance rates in the construction stage compared to the design stage over years (Figure 7). 
It is not surprising to learn that understanding and implementing the Code for Acceptance is an issue raised in focus group meetings. The code was issued just three years ago. As a special building energy code targeted to the construction and acceptance stage, the development and application of the Code for Acceptance in China is very unique, compared to building energy codes in the other six APP countries. This indicates that there is not a lot of international experience to be shared.

A somewhat surprising finding from the DOS project revealed that understanding of and compliance with the Code for Acceptance needs to be improved not only for construction companies, construction inspection companies, testing companies and quality supervision stations, but also for building developers and equipment and building materials supply companies. They are all directly or indirectly involved in the implementation of the Code for Acceptance.

\subsubsection{New Training Topics}

At least five new training topics emerged from the focus group meetings:

- Introduction to energy-saving building materials including comparison, pictures, and product catalog;

- Introduction to building technology including best practice, case studies, and construction design guideline, which specifies the construction procedures with instructional notes, pictures and figures;

- Energy-saving calculation software including case studies, introduction and application;

- Introduction to building life-cycle cost analysis, including concept, case studies, and calculation software; and

- General information regarding building energy efficiency

In response to the identified training topics from the focus group meetings, the project team developed such training materials as (1) a comparison of wall thermal techniques $^{48},(2)$ thermal bridge calculation in the updated residential building energy $\operatorname{code}^{49}$, (3) introduction of building energy efficiency materials and products ${ }^{50}$, (4) calculation software for linear heat transfer coefficient of thermal bridge ${ }^{51},(5)$ KmCAL calculation software ${ }^{52}$, as well as presentations and reports about China's energy conservation policies, building energy efficiency, and building energy codes. These training materials need to be further tested and improved for future training projects.

\footnotetext{
${ }^{48}$ http://zmjnpx.chinabec.cn/tabid/183/ArticleID/4675/Default.aspx

49 http://zmjnpx.chinabec.cn/tabid/183/ArticleID/4648/Default.aspx

${ }_{50} \mathrm{http} / / /$ zmjnpx.chinabec.cn/tabid/183/ArticleID/4674/Default.aspx

${ }_{52}^{51}$ http://zmjnpx.chinabec.cn/tabid/183/ArticleID/4673/Default.aspx

$52 \underline{\text { http://zmjnpx.chinabec.cn/tabid/183/ArticleID/4672/Default.aspx }}$
} 


\subsection{Targeted Trainees}

\subsubsection{Building Developers, Construction Workers, and Consumers}

The conventional audience for building energy codes training consists of building designers, drawing inspectors, construction managers, construction inspectors, quality supervisors, and code offices. This long list of trainees excludes real estate companies or developers, construction workers, and the general public, with a possible underlying assumption that their roles are limited in the compliance of building energy codes.

In reality, real estate companies or developers initiate a construction project and make critical decisions related to financing the project, selecting building design companies, drawing inspection companies, construction companies, construction inspection companies, testing companies and labs through bidding processes and selling new constructions. A recent DOE report entitled "Who Plays and Who Decides," emphasized that it is those who supply the money that are typically the ultimate decision makers of how well the building is constructed (Reed, Johnson, Riggert and Oh, 2004).

Nevertheless, understanding of building energy

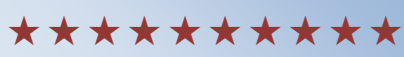

There is a need to provide training to construction workers and for information to be disseminated to real estate companies or developers, and consumers in the future projects.

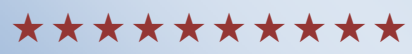
codes and building energy efficiency by real estate companies or developers certainly influences the development and compliance of a construction project.

Construction workers are the entity that realizes building design and code requirements through nails and bricks. Their understanding of building energy codes and construction practice shape the quality of a construction project, as well as its compliance with building codes.

Consumers are buyers, users, or residents of buildings. Their awareness of building energy codes and building energy efficiency can act like an important market pull driving the compliance of building energy codes.

The current training activities are focused on the conventional trainees. There is a need, as pointed out by local stakeholders in Ningbo and Changchun, to provide training to construction workers and information disseminated to real estate companies or developers, and consumers in future projects. 


\subsubsection{Training through Communication}

Training is a special communication exercise, with specific information to be delivered and specific audience to be informed.

The conventional trainees of building energy codes often have technical backgrounds and are supposed to have adequate to good knowledge of building energy codes to perform their work. Training materials with technical jargon are acceptable, though training materials coupled with good communication techniques are always welcomed.

The unconventional trainees, such as real estate companies or developers and consumers, may possess little to no knowledge related to building energy codes. Training materials should be written in a simple, easy language with straightforward information.

Construction workers are special, unconventional trainees. They are supposed to have adequate knowledge but many may not. Their technical knowledge level is varied between adequate and inadequate. The readiness of their training materials is somewhere between these two groups. Photos of construction practices with easy language and simple information are a must for their training materials.

\subsubsection{A Draft Work Plan of Training Materials}

Based on the identified training topics and trainees, the project team would like to suggest a draft work plan of training materials for target trainees (Table 6-2).

The training materials for the Code of Acceptance should be carefully developed and tested to tailor the needs of each key stakeholder (including construction companies, construction inspection companies, testing companies, quality supervision stations, building developers and equipment and building materials supply companies). The development of these tailored training materials should be considered as a focus for future training projects.

Note that once a core set of training materials is ready, it will be easy to modify them to reflect the needs of each stakeholder. However, a task analysis needs to be performed in order to determine what each end user needs to know about the code based on their role in the construction process. This can be used to guide the development of the training materials. 
Table 6-2 A Draft Work Plan of Training Materials

\begin{tabular}{|c|c|c|c|c|c|c|c|c|}
\hline & \multirow[b]{2}{*}{ Trainees } & \multicolumn{7}{|c|}{ Key Training Topics } \\
\hline & & $\begin{array}{l}\text { Building } \\
\text { technology }\end{array}$ & $\begin{array}{l}\text { Building } \\
\text { materials }\end{array}$ & $\begin{array}{c}\text { Building } \\
\text { calculation } \\
\text { software }\end{array}$ & $\begin{array}{c}\text { Building life- } \\
\text { cycle cost } \\
\text { analysis }\end{array}$ & $\begin{array}{c}\text { Construction } \\
\text { practice }\end{array}$ & $\begin{array}{l}\text { The Code } \\
\text { for } \\
\text { Acceptance }\end{array}$ & $\begin{array}{c}\text { General } \\
\text { information about } \\
\text { building energy } \\
\text { efficiency }\end{array}$ \\
\hline \multirow{5}{*}{ 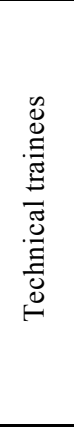 } & \begin{tabular}{|l} 
Building \\
designers
\end{tabular} & $\mathrm{X}$ & $\mathrm{X}$ & $\mathrm{X}$ & $\mathrm{X}$ & & & $\mathrm{X}$ \\
\hline & $\begin{array}{l}\text { Construction } \\
\text { managers }\end{array}$ & $X$ & $X$ & & $\mathrm{X}$ & $X$ & $\mathrm{X}$ & $\mathrm{X}$ \\
\hline & $\begin{array}{l}\text { Construction } \\
\text { inspectors }\end{array}$ & $\mathrm{X}$ & $X$ & & $X$ & $\mathrm{X}$ & $\mathrm{X}$ & $\mathrm{X}$ \\
\hline & $\begin{array}{l}\text { Testing } \\
\text { stations and } \\
\text { labs } \\
\end{array}$ & $\mathrm{X}$ & $X$ & & & & $X$ & $\mathrm{X}$ \\
\hline & $\begin{array}{l}\text { Quality } \\
\text { supervisors }\end{array}$ & $X$ & $X$ & & & $X$ & $\mathrm{X}$ & $\mathrm{X}$ \\
\hline \multirow{3}{*}{ 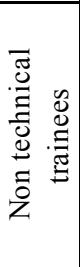 } & \begin{tabular}{|l|} 
Construction \\
workers
\end{tabular} & & $X$ & & & $X$ & $\mathrm{X}$ & $\mathrm{X}$ \\
\hline & $\begin{array}{l}\text { Building } \\
\text { developers / } \\
\text { real estate } \\
\text { companies } \\
\end{array}$ & & & & $X$ & & & $\mathrm{X}$ \\
\hline & Consumers & & & & $X$ & & & $\mathrm{X}$ \\
\hline
\end{tabular}

Note: An X indicates there is a need for training materials and information dissemination for the corresponding trainees.

\subsection{Targeted Media: Internet}

Online training and information dissemination is a popular approach used to promote building energy codes widely used by many APP countries, including Australia, Canada, the U.S., Japan, and South Korea (Appendix 4B).

China, which has the largest online population that reached 457 million by $2010^{53}$, has yet to utilize its internet power to promote training and information dissemination of building energy codes at both the national and local level. Though China has successfully promoted "e-governance" for openness and transparency of governmental management ${ }^{54}$, the concept of "e-training" of building energy codes seems innovative to both national and local stakeholders.

At the focus group meetings, local participants said that the on-line training activity was a new idea to them, but they viewed it positively. They agreed that the development of online training activities could provide greater flexibility that

\footnotetext{
${ }^{53} \mathrm{http}$ //news.yahoo.com/s/ap/20110119/ap_on hi te/as china internet population

${ }^{54}$ National and local governmental agencies are required to develop and maintain their own website with updated news regarding their activities, their contact information, and so on.
} 
conventional training seminars do not. Some participants expressed concerns that people may lack the incentive or interest to take online training. All of them agreed that providing free training may help attract more participants.

Building energy codes experts at CABR also expressed great interest in promoting building energy codes through online training activities. Although the online training is actually more time-consuming and CABR had no prior experiences conducting one, CABR suggested replacing the second onsite training in pilot cities with online training,

The DOS project provided a great opportunity to build China's first website to provide free online training of building energy codes, with training presentation slides, technical notes and reports. However, this website or an upcoming official website of building energy codes could be more informative and influential in China's building energy codes community, if the following information is available:

- Free training materials (see Table 6-2);

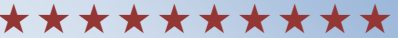

With the largest online population in the world, China has yet to utilize its internet power to promote training and information dissemination of building energy codes at both the national and local level.

- Free or fee-based downloadable or online calculation software and tools, with instruction on the application;

- Technical notes and reports, policy analysis, case studies of a specific topic;

- Best practices in China to introduce good local experiences about the development and promotion of building energy codes;

- New management concepts, best practices, case studies from other developed countries;

- National and local regulations, rules, policies and economic incentives related to building energy codes;

- Annual national inspection notice, results and analysis if any (Section 4.4);

- Feedback collection such as technical inquiries of building energy codes (explanation, application) and any questions and/or suggestions related to technical and policy aspects of building energy codes;

- Database for certified building design companies, drawing inspection companies, construction companies, construction inspection companies, testing companies and labs, and quality supervision stations;

- Announcement for job opportunities, meetings, conferences, release of new regulations, rules and policies, revised building energy codes;

- Catalog of equipment and building materials suppliers; etc. 
Online training not only provides flexibility and access to trainees, but also is equipped with different communication formats, such as webcast (recorded or live), and online interactive dialogue for fast Q\&A.

In the context of an information-overloaded age, a key issue of online training and information dissemination is how to attract trainees to go to the website and take online training. Developing information, which is easily understood and relevant to trainees' interests and needs, is a first step. The development of some kind of incentive approach (such as a certificate) could encourage trainees to be more willing to actively take training.

\subsection{The Role of Government in Training and Information Dissemination}

Compared to other market-oriented policy instruments such as labeling, the implementation of building energy codes is a more or less regulatory effort that needs the involvement of government.

China's government has a very strong presence in the establishment of monitoring and inspection systems to promote the compliance of building energy codes in urban areas (Chapter 4). However, the central government seems to provide very limited financial support to the development of and training activities related to building energy codes.

For example, CABR obtained a small amount of funding from MOHURD for the revision of Design

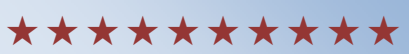

Compared to other marketoriented policy instruments, the implementation of building energy codes is a more or less regulatory effort, which needs the involvement of government.

Standard for Energy Efficiency of Residential Buildings in Severe Cold and Cold Zones (JGJ 26- 2010), and Design Standard for Energy Efficiency in Residential Buildings in the Hot Summer and Cold Winter Zone (JGJ134-2010). The funding barely met the basic labor cost and only supported one national training seminar that only attracted about one hundred participants. In addition, CABR does not have sufficient funding devoted to $R \& D$ related to building energy codes that code experts feel important. Instead, CABR has to seek funding from the market for self support. In addition, China has not invested in building an official website devoted to providing free training and information of building energy codes, where many APP countries (such as Canada, Australia, Japan and the U.S.) have such a website.

This section will first introduce the role of U.S. government in the promotion of building energy codes through training and information dissemination then discuss possible strategies that China may be interested in pursuing. 


\subsubsection{The U.S. Experiences}

The U.S. has been developing building energy standards and codes for more than thirty years, the longest development history of all APP countries. The development is mainly driven by federal legislation, undertaken by private sector code developers, and supported by the U.S. Department of Energy (DOE) (Halverson, Shui and Evans, 2009). The U.S. federal government plays an important role in promoting the development and compliance of building energy codes, through its support of policy, $\mathrm{R} \& \mathrm{D}$, finance, and information dissemination.

DOE's Building Energy Code Program (BECP) is a federal governmental program in charge of the promotion, coordination, and training of building energy codes. It maintains the largest information hub in the U.S. for building energy codes information (www.energycodes.gov), and provides free on-line training materials to the community. The training materials include a detailed training presentation of the previous and updated versions of building energy codes in both PDF and webcast formats, case studies, technical reports, short technical notes, and compliance software for residential and commercial buildings.

As part of the effort of promoting the adoption of building energy codes, BECP regularly updates code adoption maps and local jurisdiction contact information (Figures 6-1 and 6-2), with the color coding indicating different versions of residential and commercial building energy codes adopted by state. The status maps help not only to reflect the current status of a state, but also provide vivid comparisons of adoption status among states (Halverson et al 2009).

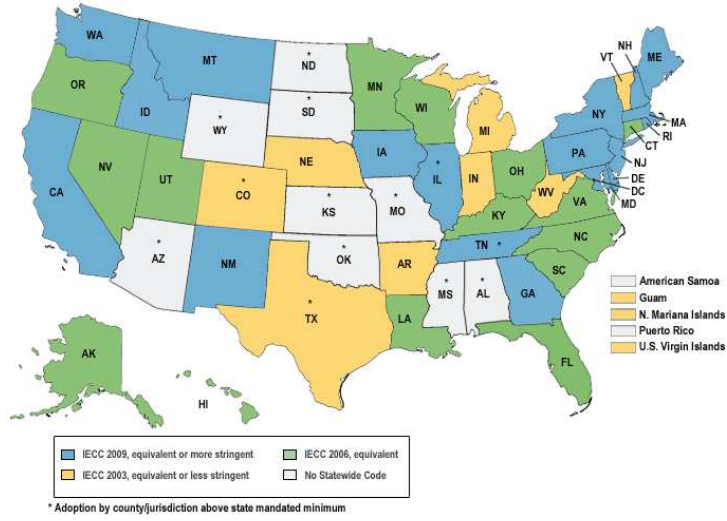

Figure 6-1 The Adoption of Residential Building Energy Codes by State

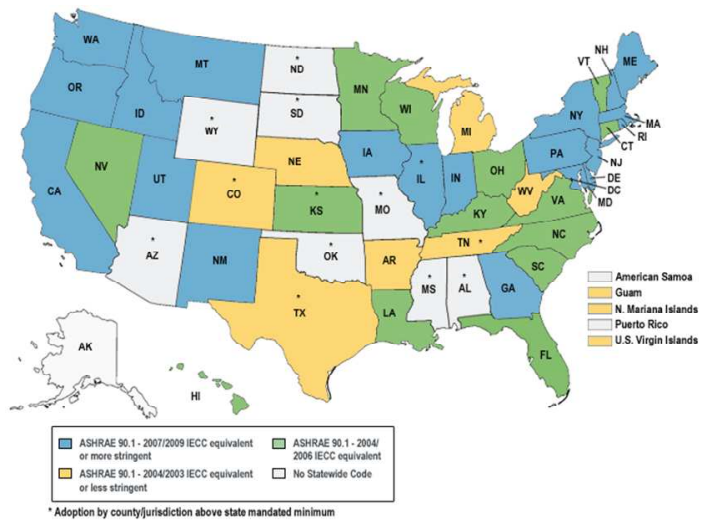

Figure 6-2 The Adoption of Commercial Building Energy Codes by State

Source: DOE, 2011 
Since1998, BECP has organized an annual conference of building energy codes, attended by several hundred local code officials and other key stakeholders. The annual conference often lasts about four days, with a busy schedule focused on training of the updated building energy codes, sharing local experiences on adoption and compliance, and touring technical sites.

As an administrative entity, BECP works closely with DOE laboratories, such as PNNL and National Renewable Energy Laboratory (NREL), to develop strategies and work plans for the promotion of building energy codes.

With financial support from DOE, the DOE laboratories provided full technical support for BECP, including developing training materials of building energy codes, conducting training through webcasts, and developing technical notes and reports, etc.

DOE provides significant financial support not only to national laboratories, which ensures high-quality technical support but also to non-governmental advocacy groups such as Building Code Assistance Project (BCAP, http://bcap-energy.org/). Nearly all of DOE-funded training materials are free to the public.

\subsubsection{What China May Consider Doing}

There are several strategies that the central government may consider doing to improve the implementation of building energy codes:

1) MOHURD may consider increasing its $R \& D$ funding to $C A B R$ and other building research and policy entities to develop high-quality training materials, technical reports, case studies and policy analysis related to the development and implementation of building energy codes.

2) MOHURD may consider providing financial resources to user support services, such as answering questions pertaining to code development and implementation from the building and design industry. This would be similar to what $\mathrm{BECP}$ is doing: when providing training, the technical assistance to back up the training needs to be provided.

3) MOHURD, or its entrusted entity such as CABR, may consider organizing an annual conference of building energy codes targeted to key stakeholders, which will provide opportunities for training, experiences exchanges, policy discussions, and business exhibitions. Chinese building energy codes experts are more than welcome to attend the BECP conference. 
4) Many provincial and local construction commissions (such as Changchun and Ningbo) have developed their own policy and technical reports about the development and implementation of building energy codes. Many of them have good experiences and lessons on the issues. MOHURD may consider encouraging information sharing between them, or compile the best practice studies for distribution.

5) MOHURD may consider establishing and maintaining an official website of building energy codes.

6) The websites of local construction commissions may consider adding a section of building energy efficiency with published local research and technical reports on the issues.

7) The local government may consider supporting their own development of training materials focused on local building energy codes.

\subsection{Enforcement in Rural Areas}

China's population in rural areas is about 19\% larger than in urban areas. However, buildings in rural areas have been left out of the current monitoring and inspection system for two reasons: (1) the apartment buildings targeted by the existing residential building energy codes do not apply for low-rise residential buildings (most of them are single houses) in rural areas. (2) The Chinese government is focusing on the enforcement of building energy codes in urban and suburban areas for now. Although some buildings in rural areas may be applied to the current residential and commercial building energy codes, there are few monitoring and inspection infrastructures built in rural areas available for service. It is, however, encouraging that China has started to look into the enforcement issues in rural areas since late 2009 .

So, the enforcement in rural areas may start from three fronts:

First, MOHURD may consider developing building energy codes for residential buildings in

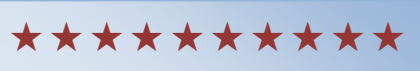

China may consider developing building energy codes for low-rise residential buildings in rural areas. rural areas. The development experiences of residential building energy codes in Japan, the U.S., Canada and Australia may provide a good reference for China. 
Second, MOHURD, or international funding agencies, may consider supporting the development of training materials focused on home builders and local construction companies in rural areas. Since the education level of both home builders and local construction companies is about elementary school, the information of training materials would be better conveyed using very simple language, with more pictures/photos and fewer technical terms. The contents of training materials may focus on building life-cycle cost and introduction of building materials (Shui et al., 2011).

Third, national or local government may help expand enforcement institutions in urban and suburban areas to rural areas in pilot sites through regulatory and financial (such as incentives) support. 


\section{Conclusions}


The DOS project was one of the first large-scale U.S.-China collaborative projects related to building energy codes in China. This project was developed in the midst of China's fast-evolving policy environment, in which China has been pushing through a series of notable regulatory and economic efforts to improve its building energy efficiency.

The DOS project, supported by both the U.S. and Chinese governments, aimed to help China implement building energy codes through training and information dissemination activities. The project not only provided an excellent learning and collaboration opportunity for the building energy codes communities of both countries, but also supported many innovative project activities for the first time:

- $\quad$ The DOS project produced China's first building energy codes training website, with free online training materials and related information;

- $\quad$ CABR and PNNL conducted China's first online training activity, with $\mathbf{5 8 0}$ viewers nationwide in the first two months;

- $\quad$ The DOS project conducted two on-site training seminars in Changchun and Ningbo, with more than 140 local participants;

- $\quad$ PNNL introduced China's first enforcement mechanism and status at a very influential U.S. building energy efficiency conference;

- $\quad$ PNNL first introduced U.S. experiences on training and information dissemination of building energy codes to a Chinese audience. The report is PNNL's first technical report written in Chinese;

- $\quad$ CABR uploaded their full-version training materials of four national building energy codes online for the first time;

- $\quad$ The project team conducted the first in-depth policy analysis of China's implementation of building energy codes, through stakeholder meetings, focus group meetings, on-site and online training, and on-site construction visits.

With nearly two and half years of project activities, the project team would like to provide the following assessment of and suggestions about the implementation of building energy codes in China:

First, China has been establishing a rather robust implementation system of building energy codes in urban areas since the mid-2000's, especially in large- and mid-size cities that underwent national inspection for building energy efficiency. The compliance rates of building energy codes at both the design and construction stages in the inspected cities are very impressive. The intensive engagement of third-parties 
in the implementation process, the release of the Code for Acceptance, and the annual national inspection for building energy efficiency are unique experiences to China.

Second, the implementation status of building energy codes in small cities and towns in less developed regions is more challenging. The development and enforcement of building energy codes in rural areas has not yet started.

Third, there is a weak and underinvested area in China's current implementation system: training and information dissemination. The project team identified training topics, extended the list of trainees, and recommended the use of the internet to promote e-training and e-learning activities. Central and local governments may consider providing financial support for offline (the development of training materials), online (an official building energy codes website, online training) and onsite (training seminars, annual national conference of building energy codes) training activities, while providing organizational support for information sharing activities.

The DOS project greatly improved the understanding of the implementation status of building energy codes in China within the international code community and laid a solid foundation for future international collaboration on the implementation of building energy codes between China and other countries.

The project team hopes that the conclusion of the DOS project will be the start of more rewarding collaborative experiences between building energy codes communities in both countries. 


\section{Appendix 1A Design Standard for Energy Efficiency of Residential Buildings in Severe Cold and Cold Zones (JGJ 26- 2010)}

1. General Provisions

2. Terms and Symbols

2.1 Terms

2.2 Symbols

3. Climate Sub-zone and Calculation Parameter of Indoor Thermal Environment

4. Building and Envelope Thermal Design

4.1 General Requirements

4.2 Envelope Thermal Design

4.3 Building Envelope Thermal Performance Trade-off

5. Energy Efficiency Design on HVAC System

5.1 General Requirements

5.2 Heat Source, Heating Plant and Heat Supply Network

5.3 Heating System

5.4 Ventilation and Air-conditioning System

Appendix A Climate Zone Criteria, Weather Data, Heat Loss Index Requirements of Building for Cities

Appendix B Methodology for Mean Heat Transfer Coefficient and Linear Heat Transfer Coefficient of Thermal Bridge

Appendix C Calculation of Heat Transfer Coefficient of Ground of Building

Appendix D Simplification on Building Shading Coefficient

Appendix E Correction Factor of Building Envelope $(\varepsilon)$ and Temperature

Difference Correction Factor of Enclosing Balcony $(\xi)$

Appendix F Building Area and Volume

Appendix G Minimum Thickness of Heating Pipe's Insulation Layer ( $\delta$ min)

Explanation of Wording in This Code

List of Quoted Standards

Addition: Explanation of Provisions 


\section{Appendix 1B Design Standard for Energy Efficiency of Residential Buildings in Hot Summer and Cold Winter Zone (JGJ 134-2010)}

1 General Provisions

2 Terms

3 Calculation Index for Indoor Thermal Environmental Design

4 Building and Building Envelope Thermal Design

5 Building Envelop Thermal Performance Trade-off

6 Energy Efficiency Design on HVAC System

Appendix A Building Area and Volume Calculation

Appendix B Calculation for the Mean Heat Transfer Coefficient of External Walls Appendix C Simplification on Building Shading Coefficient

Explanation of Wording in This Code

List of Quoted Standards

Addition: Explanation of Provisions

\section{Appendix 1C Design Standard for Energy Efficiency of Residential Buildings in Hot Summer and Warm Winter Zone (JGJ 75-2003)}

1. General Provisions

2. Terminology

3. Design Indices for Building Energy Efficiency

4. Envelope

5. Overall Evaluation of Building Energy Efficiency Design

6. Heating, Ventilation and Air Conditioning

Appendix A - Simplified Calculation Method for Exterior Shading Coefficient Appendix B - Simplified Calculation Method of Annual Electricity Consumption for Air Conditioning and Heating 


\section{Appendix 2 Design Standard for Energy Efficiency of Public Buildings (GB 50189-2005)}

1 General Provisions

2 Terminology

3 Indoor Environment Energy Efficiency Design Calculation Parameters

4 Building and Building Thermotechnical Design

5 HVAC Energy Efficiency Design

5.1 General Provisions

5.2 Heating

5.3 Ventilation and Air Conditioning

5.4 Cold/Heat Source of the Air Conditioning and Heating System

5.5 Monitoring and Control

Annex A Building external shading coefficient calculation method

Annex B Building envelope trade-off option calculation

Annex C Cost-effective insulation thickness of the cold- and hot-water pipeline of air conditioning system in the building

Explanation of Wording in This Code 


\section{Appendix 3 Code for Acceptance of Energy Efficient Building Construction (GB 50144-2007)}

1 General Provisions

2 Terms

3 Basic Requirements

3.1 Technologies \& Management

3.2 Materials \& Equipments

3.3 Construction \& Control

3.4 Classification of Acceptance

4 Energy Efficient Work of Wall

4.1 General Requirements

4.2 Dominant Items

4.3 General Items

5 Energy Efficient Work of Curtain Wall

5.1 General Requirements

5.2 Dominant Items

5.3 General Items

6 Energy Efficient Work of Doors \& Windows

6.1 General Requirements

6.2 Dominant Items

6.3 General Items

7 Energy Efficient Work of Roofing

7.1 General Requirements

7.2 Dominant Items

7.3 General Items

8 Energy Efficient Work of Floor

8.1 General Requirements

8.2 Dominant Items

8.3 General Items

9 Energy Efficient Work of Heating

9.1 General Requirements

9.2 Dominant Items

9.3 General Items

10 Energy Efficient Work of HVAC 


\subsection{General Requirements}

10.2 Dominant Items

10.3 General Items

11 Energy Efficient Work of Refrigerating \& Heating Source and Pipe

Networks of Air-Conditioning \& Heating System

\subsection{General Requirements}

11.2 Dominant Items

\subsection{General Items}

12 Energy Efficient Work of Power Distribution \& lighting

12.1 General Requirements

12.2 Dominant Items

12.3 General Items

13 Energy Efficient Work of Monitoring \& Control

13.1 General Requirements

13.2 Dominant Items

\subsection{General Items}

14 Site Inspection of Building Energy Efficiency Work

14.1 In-situ Inspection of Building Envelope

14.2 Testing on System Energy Efficient Performance

15 Quality Acceptance of Divisional Work of Building Energy Efficiency

Appendix A Re-inspection Items of Materials \& Equipments on Construction Site of Building Energy Efficient Works

Appendix B Forms for Quality Acceptance of Building Energy Efficient Divisional, Sub-divisional Works \& Inspection Lots

Appendix C Inspection of Energy Efficient of External Wall with Core Drilling Method

Explanation of Wording in This Code 


\section{Appendix 4A Enforcement Framework in APP Countries ${ }^{55}$}

\section{Highlights of enforcement framework in APP countries are}

- $\quad$ Building design inspection practices

- Local governments in Australia, Canada, Japan, South Korea and the U.S. have a major role in verifying code compliance for all or part of a building's design;

○ Japan and the U.S. may bring in third parties to oversee the design stage; and

- In South Korea, the national government may also take part in code enforcement during this stage.

- $\quad$ Building construction inspection practices

- In Australia, Canada, South Korea and the U.S. are similar, and local governments have a major role in verifying code compliance for construction; and

- Japan only supervises the building design, and does not inspect construction for building energy codes issues.

- $\quad$ Two special countries

- China relies heavily on third parties, both in the building design and construction stages. A local semi-governmental agency oversees the inspection process conducted by third parties; and

- India does not enforce its voluntary code. Since state and local governments would need to adopt the code for it to become mandatory, these governments would likely have a large role in enforcement, as they do with other building code issues.

- $\quad$ Penalties and incentives for violation and compliance

○ Common consequences for non-compliance include prohibiting a property owner from occupying a building, publishing the names of non-compliant property owners and issuing fines; and

o Rewards for compliance commonly involve one or more of the following: monetary awards, relaxation of zoning requirements for a building, low interest rates from banks and other lending institutions, and tax benefits.

\footnotetext{
${ }^{55}$ The contents in Appendix 4A are based on Shaping the Energy Efficiency in New Buildings: A Comparison of Buildings Energy Codes in the Asia-Pacific Region (Evans et al,. 2009), with some revisions.
} 

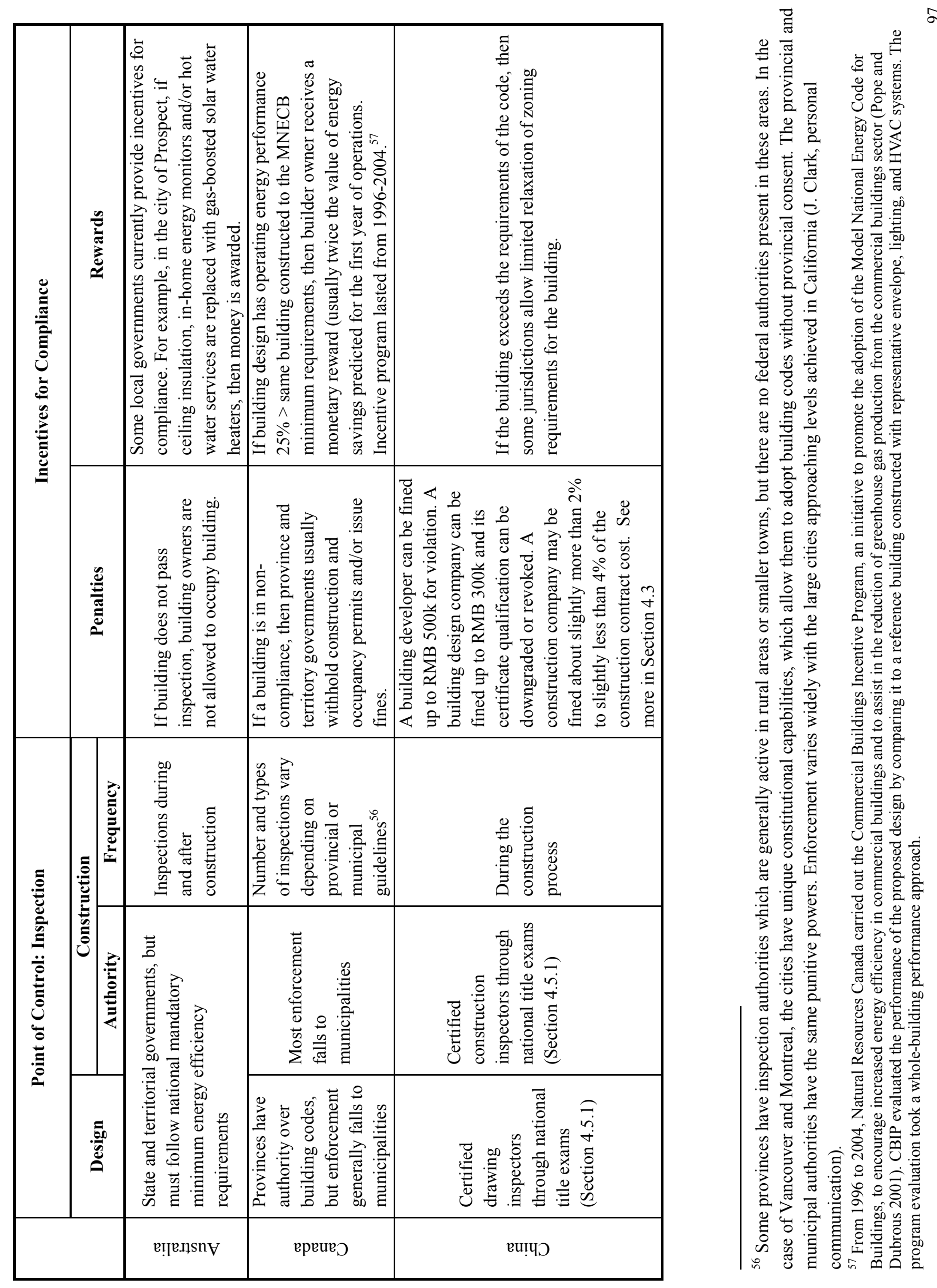

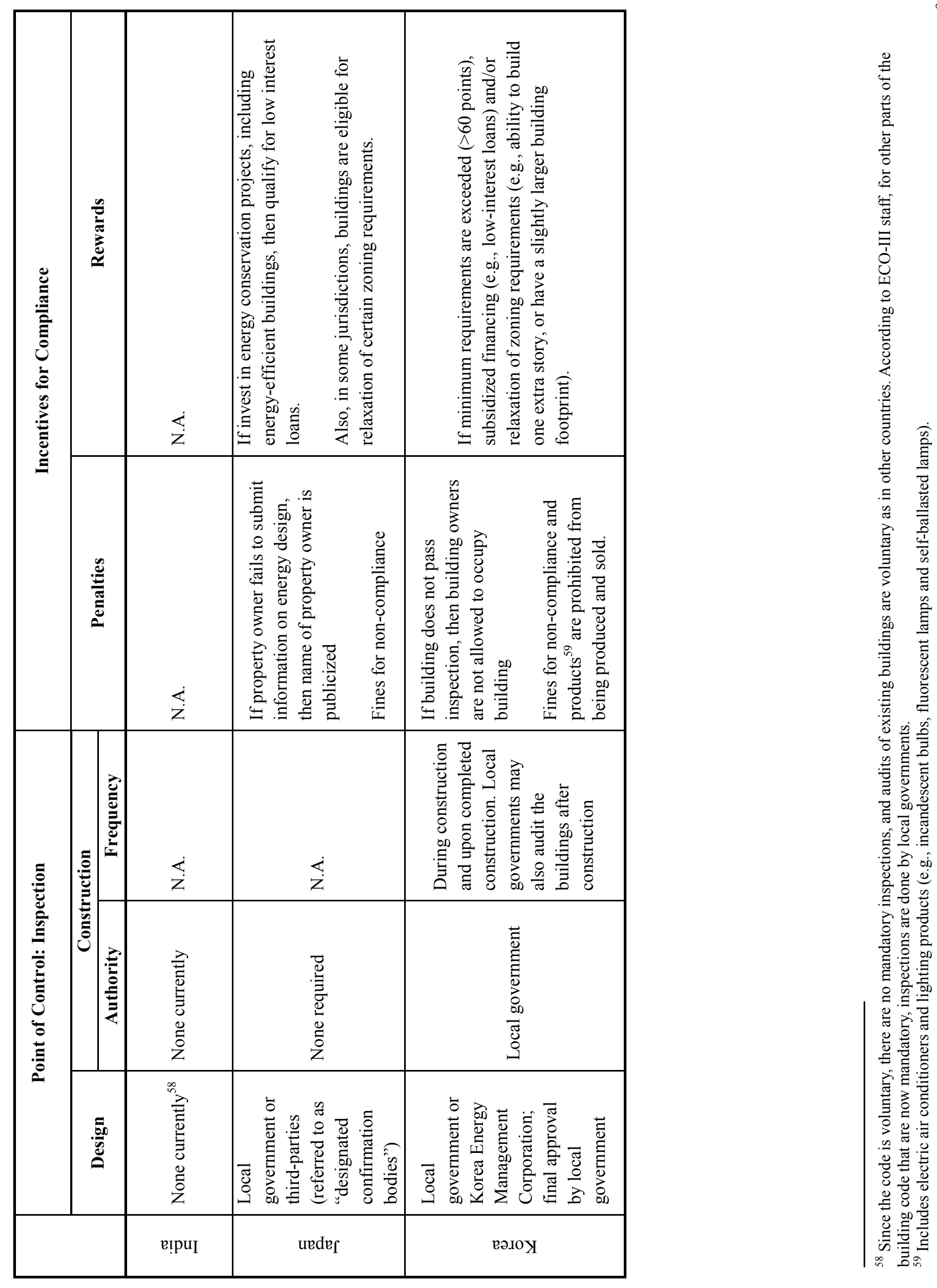

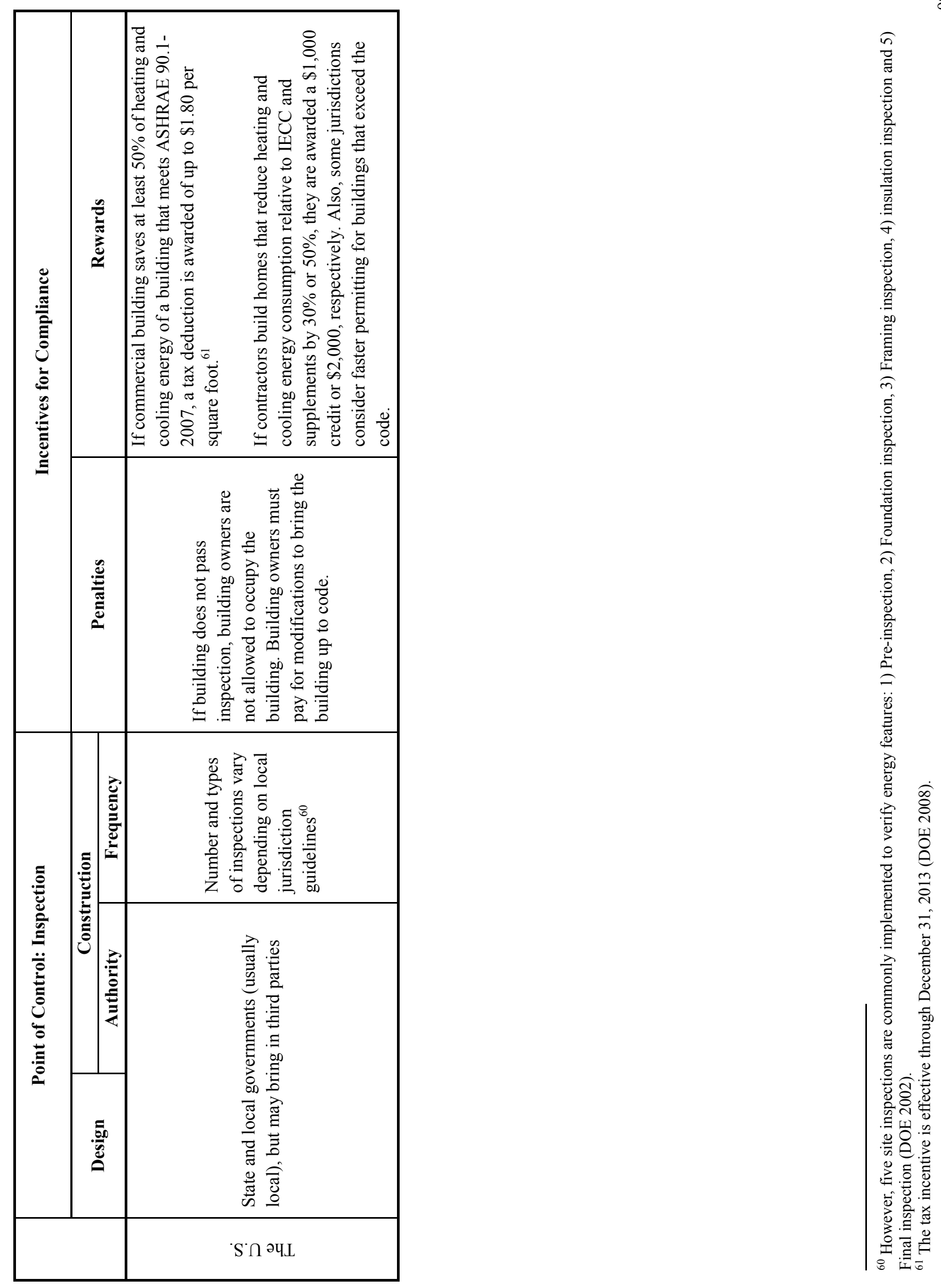


\section{Appendix 4B Training and Information Dissemination in APP Countries $^{62}$}

\section{Highlights in training and information dissemination activities in APP countries}

- $\quad$ All APP countries offer building codes training seminars, but the content and frequency of training varies.

- Some seminars provide instructions on how to implement specific code provisions (e.g., HVAC or insulation).

- $\quad$ Other seminars specifically instruct builders how to ensure compliance to codes and rating schemes (e.g., Australia).

- $\quad$ Several APP countries offer training guides, manuals, and regularly updated websites that offer current information on code compliance protocols and regulations.

\footnotetext{
${ }^{62}$ The contents in Appendix 4A are based on Shaping the Energy Efficiency in New Buildings: A Comparison of Buildings Energy Codes in the Asia-Pacific Region (Evans et al., 2009), with some revisions.
} 

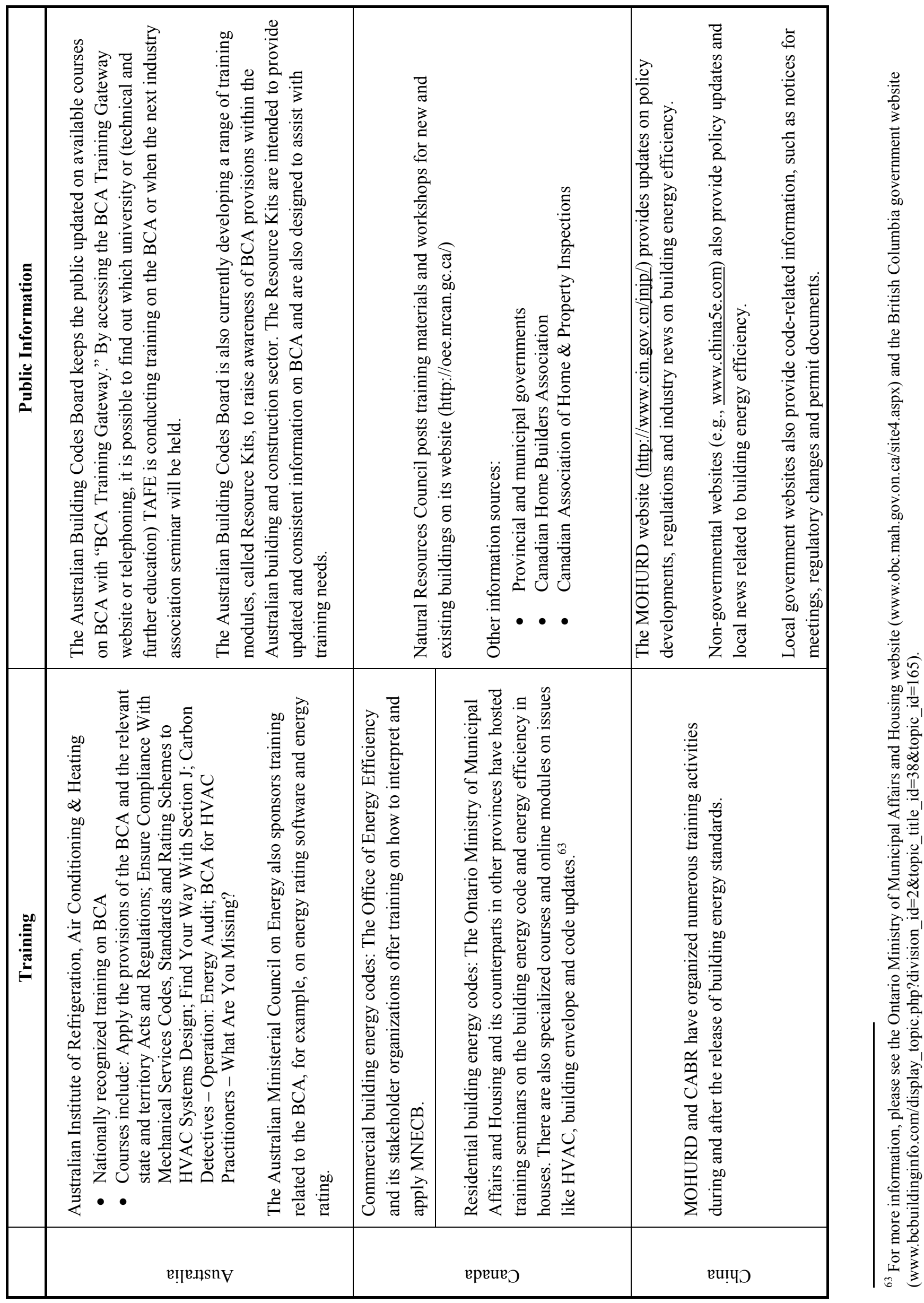


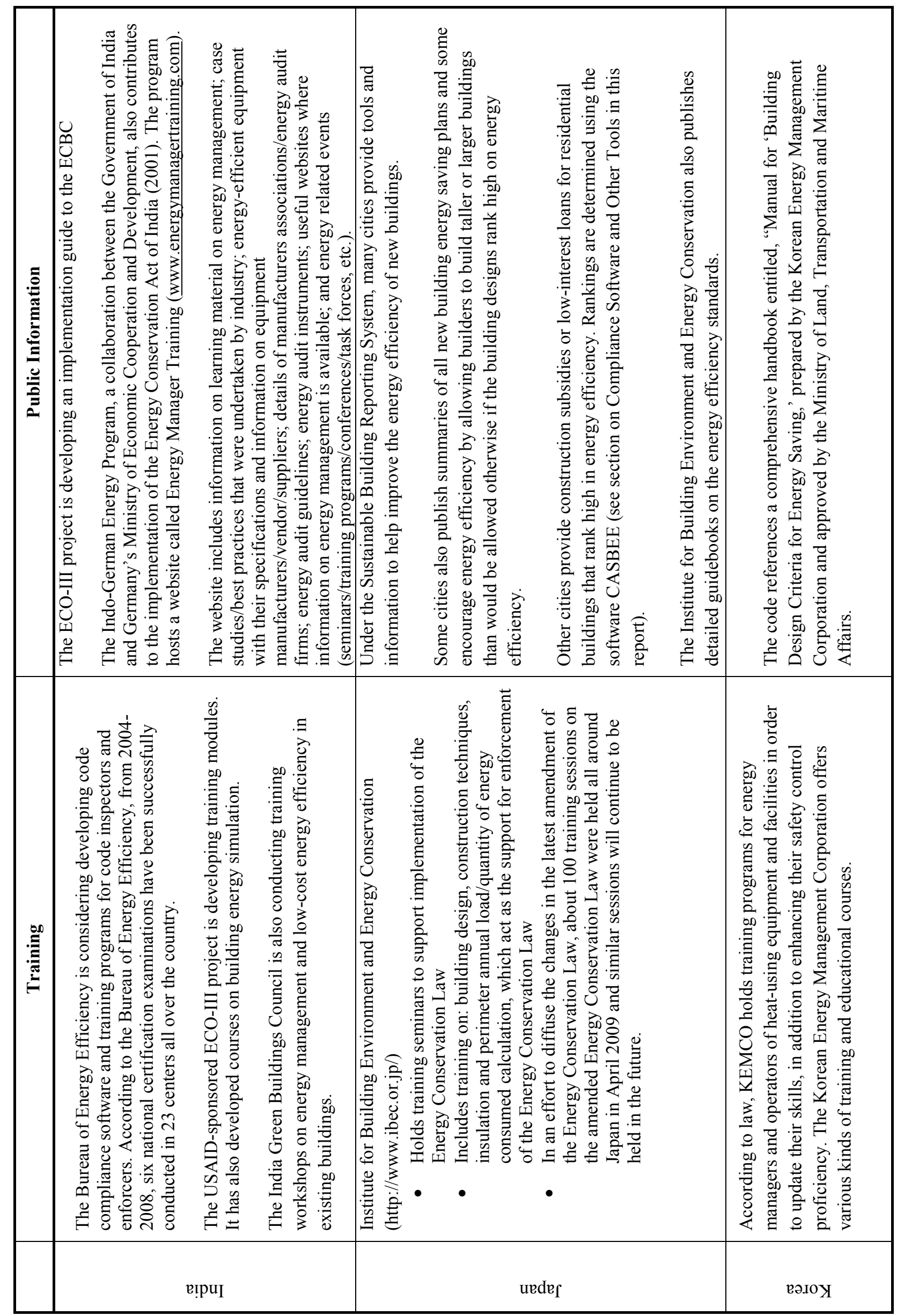




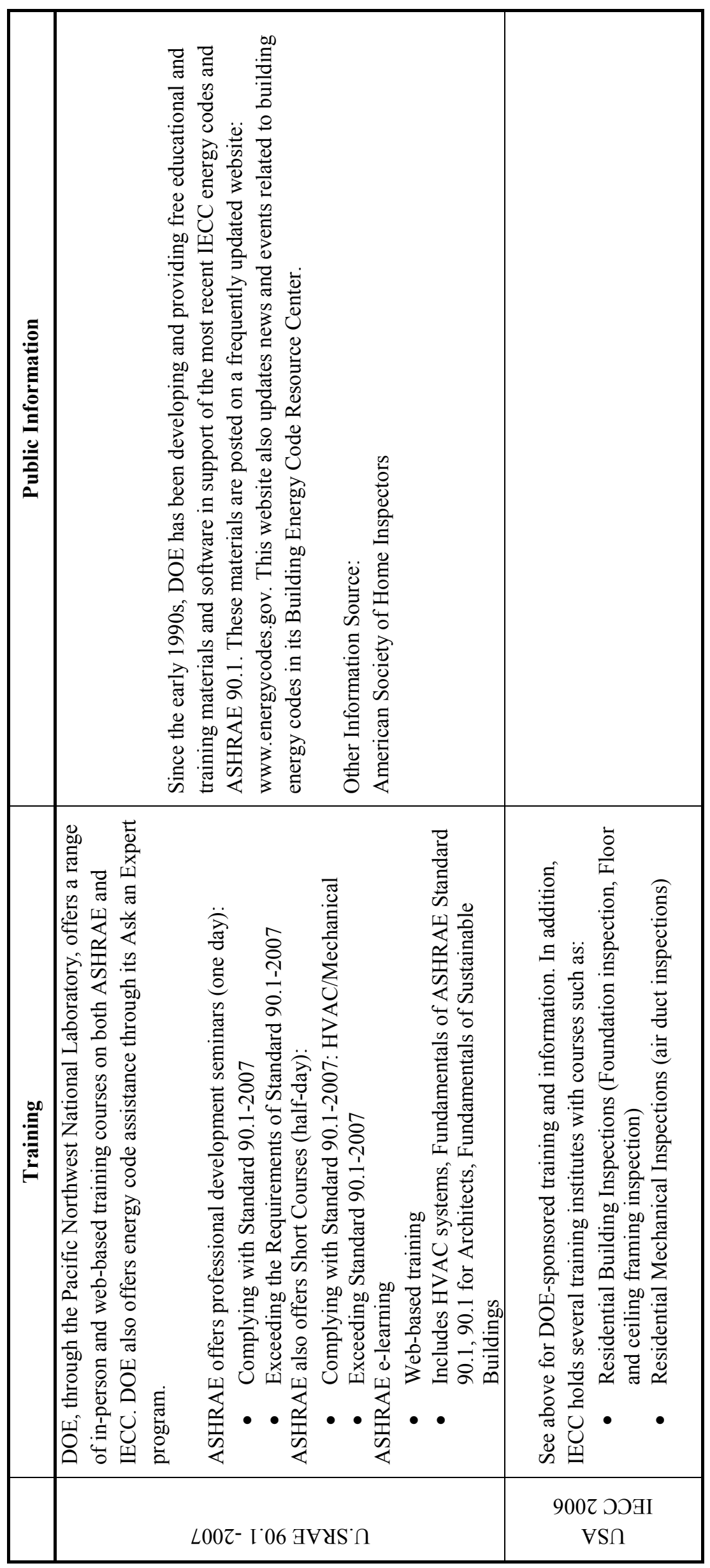




\section{Appendix 5 Building Software in China ${ }^{64}$}

Most Chinese building designers use software to ensure that their designs comply with the building energy code. There are several software packages available on the market, all privately developed and available for a fee.

The most commonly used software is called PKPM-Energy, with a market share of between 50 and 70\%. PKPM is Chinese software that functions like Auto-CAD, allowing building designers to develop the detailed plans for a building (CABR 2009). There are four options for add-on software to check for compliance with the energy code, one for each of the national building energy codes; for simplicity, we will call these add-ons collectively PKPM-EC (for energy conservation).

PKPM-EC can automatically check the building design for compliance with the energy code. Unlike U.S. energy code software, PKPM-EC is fully integrated into the building design software, which can save a lot of time and, as such, allow architects to better integrate energy features into the building. PKPM-EC first reviews a complete design to determine if it meets the prescriptive requirements of the code. If it does not, it then runs building energy simulation software (based on the U.S. DOE-2 software) to see if the building complies via the performance path. The fact that it integrates building energy simulation software is also an innovation. (The main U.S. software, COMcheck $^{\mathrm{TM}}$ and REScheck ${ }^{\mathrm{TM}}$, do not now integrate simulation, but rather allow designers to easily consider simple trade-offs to the prescriptive requirements of the code.) However, the simulation in Chinese software can also cause problems because it requires additional expertise to use properly. Many building designers do not have significant expertise in building energy simulation software, so they may mistakes, which in turn can negatively impact the actual compliance of the design.

In addition to the PKPM-EC software, there is also separate but compatible software for code officials to review the results. Other major competitors to PKPMEC include TianZheng and Si Wei Er (the latter uses a simulation engine designed by Tsinghua University instead of DOE-2). Unlike in the U.S., users must pay for the software.

\footnotetext{
${ }^{64}$ This session is cited from Enforcing Building Energy Codes in China: Progress and Comparative Lessons (Evans, M., B. Shui, M. Halverson \& A. Delgado, 2010)
} 


\section{Appendix 6 A List of Project Activities}

\begin{tabular}{|c|c|}
\hline Dates & Project Activities \\
\hline $\begin{array}{l}\text { Jan - } \\
\text { Mar, } \\
2009\end{array}$ & $\begin{array}{l}\text { - PNNL staff attended a U.S. DOE meeting (Jan 30) to introduce the project } \\
\text { and discuss possible coordination with other DOE partners working on } \\
\text { China's building energy efficiency. } \\
\text { - } \quad \text { The project team selected and confirmed the pilot cities. } \\
\text { - } \quad \text { Each subcontract to CABR and BECon was placed. } \\
\text { - PNNL traveled to Beijing (February and March 2009) to meet members } \\
\text { from the key institutions and introduce the project. The key institutions } \\
\text { include the National Development and Reform Commission (NDRC), China } \\
\text { Association of Mayors, the China Sustainable Energy Program, World Bank } \\
\text { - China Office, China Energy Conservation and Environmental Protection } \\
\text { Technology Investment Co. and the International Finance Corporation (IFC) } \\
\text { - China Office (see PNNL (2009) } 1^{\text {st }} \text { Quarter Report for details). } \\
\text { PNNL and CABR staff traveled to pilot cities Ningbo and Changchun } \\
\text { (February and March) to attend two stakeholder meetings (more than } 20 \\
\text { participants for each meeting) and collect key information regarding the } \\
\text { design and implementation of building energy codes in these two cities } \\
\text { (Appendixes } 2 \text { and 3). } \\
\text { A CABR team member visited the State Department (March). }\end{array}$ \\
\hline $\begin{array}{c}\text { Apr - } \\
\text { Jun, } 2009\end{array}$ & $\begin{array}{l}\text { - A CABR team member conducted training activities in the Xingjiang } \\
\text { Autonomous Region, Sichuan Province on the compliance of building } \\
\text { energy codes (April - June). } \\
\text { - PNNL prepared a list of implementation and training questions for the pilot } \\
\text { cities (Appendix 1), and discussed with CABR potential problems in local } \\
\text { compliance and enforcement of building energy codes. } \\
\text { - PNNL's project trip was cancelled due to the H1N1 flu in China. }\end{array}$ \\
\hline
\end{tabular}




\begin{tabular}{|c|c|}
\hline Dates & Project Activities \\
\hline $\begin{array}{c}\text { Jul }- \text { Sep } \\
2009\end{array}$ & $\begin{array}{l}\text { - CABR and PNNL co-organized training workshops in the pilot cities, with } \\
140 \text { local participants in total. } \\
\text { - } \quad \text { The project team visited a construction site in Changchun. } \\
\text { - } \quad \text { PNNL visited CABR to learn about the development of compliance } \\
\text { software. } \\
\text { - PNNL and CABR discussed training and public information activities for } \\
\text { the following project year. } \\
\text { PNNL and CABR co-organized an international seminar on the } \\
\text { implementation of building energy codes of APP countries in Beijing. The } \\
\text { project team and pilot cities, as well as other domestic and international } \\
\text { experts on building energy codes attended the seminar. } \\
\text { BECon co-organized an informal US-China workshop with the U.S.-China } \\
\text { Clean Energy Forum, and PNNL was invited to attend. The workshop } \\
\text { intended to collect information to prepare for President Obama's visit to } \\
\text { China in November } 2009 \text {. }\end{array}$ \\
\hline $\begin{array}{c}\text { Oct }- \text { Dec, } \\
2009\end{array}$ & $\begin{array}{l}\text { PNNL and CABR worked to develop a detailed work plan for the second } \\
\text { project year. } \\
\text { - The PNNL project team attended a public code hearing of International } \\
\text { Energy Conservation Code (IECC), hosted by International Code Council } \\
\text { (ICC) in late October. The IECC is one of DOE's main focal points for } \\
\text { development of US residential and commercial codes. } \\
\text { - The PNNL project team exchanged information on the DOS project to } \\
\text { relevant personnel at the World Bank. } \\
\text { BECon prepared a draft technical report on building energy efficiency } \\
\text { (including building energy codes) in China. The report will provide good } \\
\text { background on Chinese policies and projects related to the promotion of } \\
\text { building energy efficiency. } \\
\text { In late December, the PNNL team met with the new DOS project team at } \\
\text { the State Department. The PNNL team briefed the project developments } \\
\text { and updates, especially on the development of a draft new work plan. }\end{array}$ \\
\hline $\begin{array}{c}\text { Jan - Mar, } \\
2010\end{array}$ & $\begin{array}{l}\text { - The project team developed training materials. } \\
\text { BECon finished a draft report on China's Building Energy Efficiency } \\
\text { Policy Review (in Chinese). PNNL and CABR reviewed the report. } \\
\text { - PNNL prepared project presentation slides for BATF } 8 \text { (held in Vancouver } \\
\text { on March 23, 2010). The prepared slides introduced the current project } \\
\text { activities and next steps. } \\
\text { - PNNL developed a draft web design of the upcoming CABR website, } \\
\text { which is China's first website dedicated on building energy codes. } \\
\text { PNNL summarized the current training approaches and strategies to major } \\
\text { stakeholders in the U.S. It will help the project team develop its strategies } \\
\text { to promote training activities in China. }\end{array}$ \\
\hline
\end{tabular}




\begin{tabular}{|c|c|}
\hline Dates & Project Activities \\
\hline $\begin{array}{c}\text { Apr - Jun, } \\
2010\end{array}$ & $\begin{array}{l}\text { - The project team worked to develop and update training materials, } \\
\text { including } \\
\text { CABR finished the draft of three technical notes in Chinese: (1) } \\
\text { Interior condensation problems and solutions, (2) comparison of } \\
\text { envelope insulation options, and (3) insufficient heat at the end of } \\
\text { pipeline and solutions. The materials are ready to be reviewed for } \\
\text { comments. } \\
\text { PNNL finished the journal paper draft about the introduction of U.S. } \\
\text { training and information dissemination activities. PNNL summarized } \\
\text { the current training approaches and strategies to major stakeholders in } \\
\text { the U.S. }\end{array}$ \\
\hline $\begin{array}{c}\text { Jul }- \text { Sep } \\
2010\end{array}$ & $\begin{array}{l}\text { - The project team conducted a focus group meeting in Ningbo and } \\
\text { Changchun in early August, with a total of } 25 \text { participants. } \\
\text { - The project team visited a small rural town, Chunhu Town, near Ningbo } \\
\text { City to (1) learn how the DOS project and the World Bank project (focused } \\
\text { on the promotion of building energy efficiency in Chunhu) could } \\
\text { collaborate, and (2) get feedback from them on the training materials. } \\
\text { - The PNNL team attended CABR-hosted national training of the updated } \\
\text { residential building energy codes (JGJ 26-2010 and JGJ134- 2010). } \\
\text { - The project team continued to prepare reports and training materials. } \\
\text { PNNL presented a conference paper about the implementation of building } \\
\text { energy codes in China at } 2010 \text { ACEEE Summer Study on Energy } \\
\text { Efficiency in Buildings in August. }\end{array}$ \\
\hline $\begin{array}{c}\text { Oct }- \text { Dec, } \\
2010\end{array}$ & $\begin{array}{l}\text { PNNL oversaw the development of the training website: } \\
\text { (http://zmjnpx.chinabec.cn). } \\
\text { PNNL and CABR finalized a report titled "Feedbacks from Focus Group } \\
\text { Meeting on Training and Implementation of Building Energy Codes in } \\
\text { China." } \\
\text { - The project team finalized the training materials. }\end{array}$ \\
\hline $\begin{array}{c}\text { Jan - Mar, } \\
2011\end{array}$ & $\begin{array}{l}\text { - All of training materials were uploaded to the training website. } \\
\text { - The on-line training activities were conducted in late January. } \\
\text { - The project team wrapped up the project by finishing the project } \\
\text { deliverables and disseminating training materials. }\end{array}$ \\
\hline
\end{tabular}




\section{Acronyms}

$\begin{array}{ll}\text { BECP } & \text { Building Energy Code Program } \\ \text { BMF } & \text { the Blue Moon Fund } \\ \text { CABR } & \text { China Academy of Building Research } \\ \text { DOE } & \text { U.S. Department of Energy } \\ \text { DOS } & \text { The U.S. Department of State } \\ \text { GB 50189-2005 } & \text { Design Standard for Energy Efficiency in Public Buildings } \\ \text { GB50411-2007 } & \text { Code for Acceptance of Engineering Quality of Building Energy } \\ & \text { Conservation Project } \\ \text { GDP } & \text { Gross domestic product } \\ \text { GEF } & \text { Global Environmental Facility } \\ \text { HSCW } & \text { hot summer and cold winter } \\ \text { HSWW } & \text { hot summer and warm winter } \\ \text { HVAC } & \text { Heating, ventilating, and air conditioning (HVAC) } \\ \text { JGJ 26-1995, 2010 } & \text { Design Standard for Energy Efficiency of Residential Buildings in } \\ & \text { Severe Cold and Cold Zones } \\ \text { JGJ134-2001, 2010 } & \text { Design Standard for Energy Efficiency of Residential Buildings in Hot } \\ \text { MOC } & \text { Summer and Cold Winter Zones } \\ \text { China's Ministry of Construction } \\ \text { NDRC } & \text { China's Ministry of Housing for Urban-Rural Development } \\ \text { PNNL } & \text { National Development and Reform Commission (China) } \\ \text { RMB } & \text { Pacific Northwest National Laboratory } \\ \text { U.S. } & \text { Ren Min Bi, Chinese Currency, 1 US Dollar =6.56 RMB (March 27, } \\ \text { UNDP } & \text { 2011) } \\ \text { Q \& A } & \text { United Nations Development Programme } \\ \text { R \& D } & \text { Research and Development } \\ & \end{array}$




\section{Reference}

1. BECon. 2010. Report on China Building Energy Efficiency Policies. Beijing, China

2. China Statistics Bureau. 2010. China Statistics Yearbook, http:/www.stats.gov.cn/english/statisticaldata/yearlydata/

3. Bank of China. 2011. Financial Data, http://www.bank-of-china.com/finadata/

4. DOE, 2011. Status of State Energy Codes, www.energycodes.gov/implement/state_codes/index.stm, December 2010, (Accessed)

5. EIA (Energy Information Administration). 2010a. World Carbon Dioxide Emissions from the Consumption and Flaring of Fossil Fuels, www.eia.doe.gov/emeu/international/carbondioxide.html

6. EIA (Energy Information Administration). 2010b. Residential Energy Consumption Survey 2005 - Detailed Tables, www.eia.doe.gov/emeu/recs/recs2005/hc2005 tables/detailed tables2005.html

7. EIA (Energy Information Administration). 2010c. World Carbon Dioxide Emissions from the Consumption and Flaring of Fossil Fuels, www.eia.doe.gov/emeu/international/carbondioxide.html

8. Evans M, B Shui, and A Delgado. 2009. Shaping Energy Efficiency in New Buildings: A Comparison of Building Energy Codes in the Asia-Pacific Region. PNNL-18478, Pacific Northwest National Laboratory, Richland, WA.

9. Halverson MA, B Shui, and M Evans. 2008. Country Report on Building Energy Codes in the United State. PNNL-17979, Pacific Northwest National Laboratory, Richland, WA.

10. International Energy Agency. 2007. Energy Balances of OECD Countries. Paris: IEA.

11. International Energy Agency. 2009. Energy Balances of Non-OECD Countries 1971-2007. Paris: IEA.

12. International Monetary Fund, 2010

13. Lang, Siwei. 2005. Energy Efficiency Requirements for Cooling and Heating Sources in GB50189-2005 Design Guide for Energy Efficiency in Public Buildings. China Construction Heating \& Refrigeration 7.

14. Lin, Haiyan. 2008. A Brief Introduction to the Chinese Design Standards for Energy Efficiency in Residential Buildings. Beijing: China Academy of Building Research.

15. Reed, J.H., K. Johnson, J. Riggert and A.D. Oh. 2004. Who Plays and Who Decides: The Structure and Operation of the Commercial Building Market. DE-AF26-02NT20528. Rockville, MD.

16. Shui B, H Lin, B Song, MA Halverson, M Evans, and X Zhu. 2011. Feedbacks from Focus Group Meeting on Training and Implementation of Building Energy Codes in China. PNNL-20138, Pacific Northwest National Laboratory, Richland, WA.

17. Shui B, M Evans, H Lin, W Jiang, B Liu, B Song, and S Somasundaram. 2009. Country Report on Building Energy Codes in China. PNNL-17909, Pacific Northwest National Laboratory, Richland, WA.

18. Wu, Yong, and Changbin Liu. 2007. Policy Study on China Building Energy Incentive Program. Beijing: China Construction Industry Publishing House.

19. Wu, Yong, Changbin Liu, Yingzong Liu, and Hongle Qu. 2007. Study on China Building Energy Management System. Beijing: China Construction Industry Publishing House. 